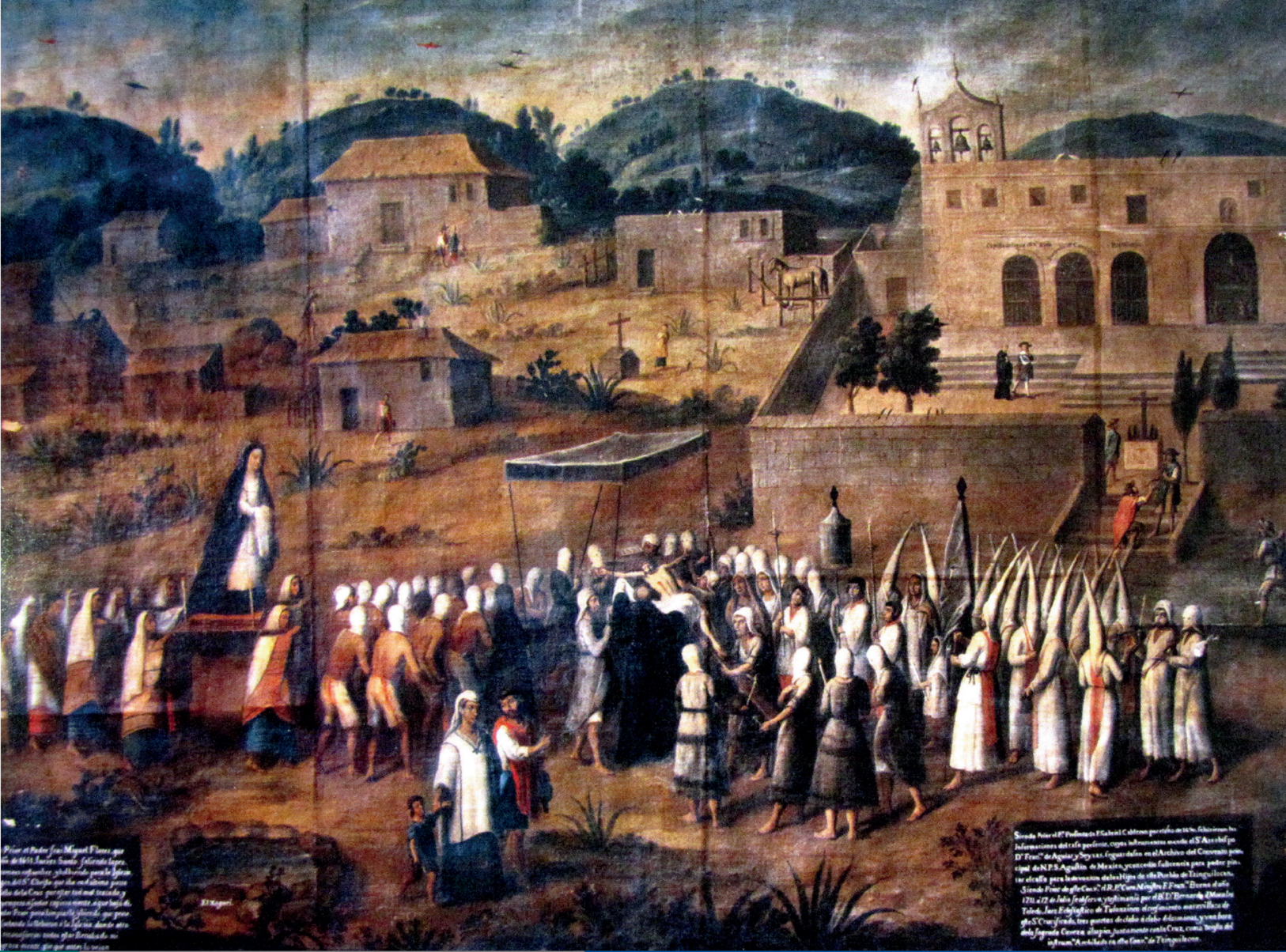

\title{
2
}

GEOGRAFIA PARA EL SIGLOXXI SERIE: LIBROS DE INVESTIGACIÓ N

Variabilidad climática en México a través de fuentes documentales (siglos XVI al XIX)

Gustavo G. Garza Merodio 




\section{Variabilidad climática en México a través de fuentes documentales (siglos XVI al XIX)}


Instituto de Geografía

Universidad Nacional Autónoma de México

Colección: Geografía para el siglo XXI

Serie: Libros de investigación, núm. 20 


\section{Variabilidad climática en México a través de fuentes documentales (siglos XVI al XIX)}

Gustavo G. Garza Merodio
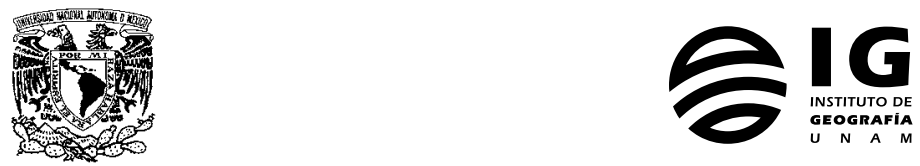

México, 2017 
Variabilidad climática en México a través de fuentes documentales (siglos XVI al XIX) / Garza Merodio, Gustavo Gerardo. - - Ciudad de México: UNAM, Instituto de Geografía, 2017.

147 p.; (Geografía para el siglo XXI; Serie Libros de investigación: 20)

Incluye síntesis de cuatro siglos de información climática en México

ISBN 970-32-2976-X (obra completa)

ISBN 978-607-02-9623-9

DOI: http://dx.doi.org/10.14350/gsxxi.li.20

1. Clima - México. 2. Clima - fuentes documentales - Siglos XVI - XIX. I Garza Merodio, Gustavo Gerardo. II Universidad Nacional Autónoma de México, Instituto de Geografía. III Serie.

Variabilidad climática en México a través de fuentes documentales (siglos XVI al XIX)

Primera edición, 11 de septiembre de 2017.

D.R. ( 2017 Universidad Nacional Autónoma de México

Ciudad Universitaria,

Coyoacán, 04510 México, Cd. Mx.

Instituto de Geografía,

www.unam.mx, www.igeograf.unam.mx

Editor académico: José Luis Palacio Prieto

Editores asociados: María Teresa Sánchez Salazar y Héctor Mendoza Vargas

Editora emérita: Atlántida Coll-Hurtado

Editor técnico: Raúl Marcó del Pont Lalli

Prohibida la reproducción parcial o total por cualquier medio, sin la autorización escrita del titular de los derechos patrimoniales.

La presente publicación presenta los resultados de una investigación científica y contó con dictámenes de expertos externos, de acuerdo con las normas editoriales del Instituto de Geografía.

Geografía para el siglo XXI (Obra general)

Serie: Libros de investigación

ISBN (Obra general): 970-32-2976-X

ISBN: 978-607-02-9623-9

DOI: http://dx.doi.org/10.14350/gsxxi.li.20

Impreso y hecho en México 


\section{Índice}

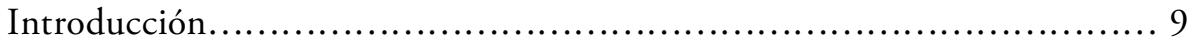

Capítulo 1. Características de la documentación.............................. 13 utilizada y sus tipos de información

Capítulo 2. México, Puebla y Morelia.................................... 27

Capítulo 3. Guadalajara y Oaxaca, comparación............................. 79 de sus datos con los del centro de México

Capítulo 4. Durango y Sonora........................................ 95

Capítulo 5. Chiapas y Yucatán......................................... 105

Conclusiones........................................................ 115

Anexo. Síntesis de cuatro siglos de información............................ 119 climática en México

Bibliografía....................................................... 145 



\section{Introducción}

El conocimiento sobre la variabilidad climática en México está por escribirse, no solo en lo que respecta a los tiempos geológicos, sino a los históricos, razón por la que es necesario conjuntar esfuerzos desde diversas aproximaciones, ya sea por medio de fuentes físico-biológicas o antrópicas.

El estudio de la variabilidad climática, en particular lo referente a la precipitación pluvial, es primordial a toda sociedad contemporánea, pero en el caso de las áreas más pobladas de México resulta aún más indispensable, ya que estos entornos carecen de grandes reservas de agua, como pueden ser extensos y profundos lagos o caudalosos ríos: varias capitales mexicanas se encuentran próximas a la divisoria continental de aguas y sus fuentes de abastecimiento y mecanismos de almacenamiento y distribución son altamente vulnerables a la ausencia de precipitación. Ante tal situación, se considera que contar con referencias precisas y aproximaciones veraces a la variabilidad de la precipitación, durante temporalidades prolongadas, puede ser altamente benéfico.

En la reconstrucción paleoclimática se tiene como única fuente precisa a los registros obtenidos por medio de instrumentos meteorológicos, pero su resolución temporal en Iberoamérica difícilmente llega a 140 años, y en Europa occidental y Norteamérica no va más allá de mediados del siglo XVIII. El resto de la reconstrucción paleoclimática se conduce por medio de proxy data, tal y como se les define en lengua inglesa y se trata de aproximaciones de origen físico-biológico (dendroclimatología, el análisis de sedimentos lacustres y marinos, así como el estudio de corales, cascos de hielo y glaciares) y antrópico (fuentes documentales). En el caso de México, la existencia de fuentes documentales en el estudio del clima, particularmente en el centro y sur del país, subsana la ausencia de otras aproximaciones fidedignas a lo largo de los últimos quinientos años. La dendrocronología también puede aportar datos para este período, pero es hasta nuestros días cuando comienza a consolidarse este tipo de investigación en el centro del país, particularmente a lo largo del Eje Neovolcánico (Stahle et al., 2011; Villanueva et al., 2016).

Dentro de la reconstrucción paleoclimática, la climatología histórica concentra las fuentes de origen antrópico por medio de dos vertientes: los registros 
instrumentales en una temporalidad prolongada y los registros documentales; homogéneos en su tipo de información y de una temporalidad continua y prolongada. Hace poco más de cinco décadas que el valor de la información documental en la reconstrucción paleoclimática comenzó a ser reconocido a escala global, gracias a los importantes aportes que brindó su utilización y análisis. Fueron académicos europeos y norteamericanos quienes condujeron en lo primordial esta labor. Destacó entre ellos a Emmanuel Le Roy Ladurie, tanto por su tenaz y profunda dedicación al trabajo de archivo como por su posición crítica ante reconstrucciones paleoclimáticas simples a través de la enunciación de eventos aislados y teleconexiones ramplonas, que en poco ayudaban a comprender a cabalidad la complejidad del comportamiento climático secular.

La honestidad intelectual de Le Roy Ladurie (1990: 361) lo llevó incluso a denunciar, hace más de cuarenta años, el abuso cometido por diversos investigadores, al solo duplicar los datos obtenidos de los glaciares de Europa y Norteamérica. Situación que, de acuerdo con este autor, se podía subsanar al conducirse nuevas catas y consultas en los acervos documentales. Entre los datos que surgieron a la luz pública más allá de su lugar de origen, gracias al esfuerzo del especialista francés, se encontraron los registros de las ceremonia de rogativa (ritos de la iglesia católica sobre los que se ahonda en el siguiente apartado). Información que desde fines de la década de 1950 venía sistematizando Emili Giralt I Raventós, en su natal Cataluña, con la finalidad de reconstruir la vida agraria y las condiciones climáticas entre los siglos XV y XIX. Los aportes de este autor se limitaron a sacar a la luz este tipo de fuentes, sin que avanzara en principios metodológicos para la construcción de series climáticas y calibración de la información.

La veracidad en la definición de trayectorias y anomalías climáticas proveniente del registro de rogativas ha sido plenamente demostrada en el ámbito mediterráneo, en donde destaca el trabajo de autores como Mariano Barriendos (1994) o Dario Camuffo y Silvia Enzi (1992), pero en Iberoamérica todavía hay un largo camino por recorrer para poder rescatar toda la información ambiental contenida en archivos civiles y eclesiásticos. En México se han consultado diecisiete de los veinte archivos que podrían contener este tipo de información, con resultados particularmente alentadores para la ciudades de México, Morelia, Puebla, Durango y Oaxaca, e informaciones menos continuas, pero que se pueden comparar con lo obtenido en las metrópolis antes mencionadas, logradas en Guadalajara, Mérida, San Cristóbal de las Casas y Hermosillo. Los detalles de catas, consultas y particularidades de los acervos, así como los resultados y la generación de series climáticas a partir de este tipo de información, se desarrollan en los siguientes capítulos de esta obra. 
Por otra parte, se piensa necesario discernir, desde una perspectiva climática, el tipo de aproximación que se realiza al dar a conocer los datos obtenidos. La exposición toma como eje rector el concepto de variabilidad climática, o más precisamente variabilidad natural del sistema climático, tal y como refiere Javier Martín Vide (2009: 53), quien aduce que: "Prácticamente todas las variables climáticas, a cualquier escala temporal que se considere, de minutos a milenios, están continuamente fluctuando, variando con respecto a un valor medio o normal.” Agrega este mismo autor que los valores extremos, e incluso las anomalías persistentes, alejadas de las medias 'normales' son parte de la variabilidad climática, lo que lo lleva a concluir que la variabilidad es una característica esencial del sistema climático.

De acuerdo con la temporalidad de los datos disponibles a partir de los registros de rogativa en México, se debe recalcar su relevancia con respecto al estudio de la Pequeña Edad de Hielo (PEH), que por mucho todavía está lejos de ser explicada en las latitudes bajas del hemisferio norte y en el hemisferio sur. Lo heterogéneo de las manifestaciones a lo largo y ancho del planeta de la PEH, muestran que este capítulo climático dista de ser un enfriamiento generalizado, ya que mientras en algunas zonas del planeta hubo descensos de temperatura en otras se dieron aumentos. Incluso en Europa occidental, a fines del siglo XVIII tuvieron lugar años de veranos ardientes con inviernos muy crudos. La información procedente de los registros de las ceremonias de rogativa en México denotan los extremos que caracterizaron a la $\mathrm{PEH}$, coincidiendo con la propuesta de una PEH húmeda a lo largo de los siglos XVI y XVII y una seca a lo largo del siglo XVIII y primera mitad del XIX; argumentación surgida de pruebas glaciológicas en los Andes centrales (Rabatel et al., 2005: 1312; Thompson et al., 1986: 363).

Por otra parte, se piensa indispensable remarcar la relación entre variabilidad climática y dinámica y virulencia epidémica, la cual quizás resulte, en ciertos ámbitos y temporalidades, difícil de rastrear, no así en el México central y meridional entre los siglos XVI y XIX, en tanto que la manifestación de capítulos epidémicos y ausencia extrema de precipitación o acusadas heladas es más que frecuente. Tal coincidencia, entre las dinámicas climática y epidémica, también se sustenta en aportes como los de Hubert Lamb (1995: 285), para quién son cuatro las principales áreas del quehacer humano que se ven afectadas por los cambios y las fluctuaciones climáticas:

1. Abastecimiento de agua, particularmente niveles del manto freático y de los cuerpos de agua sobre la superficie, y, por ende, de la energía que generan. Humedad en el suelo. 
2. Temperaturas extremas y efectos sobre humanos y animales, demanda de combustible y desarrollo de las cosechas.

3. Radiación solar, humedad y nubosidad, sus efectos sobre la salud y el crecimiento de los vegetales, así como el potencial de la energía solar.

4. Viento extremo o acusada ausencia del mismo y sus efectos sobre infraestructuras y en la producción de energía. Los efectos de la evaporación sobre las cosechas y la biota en general y en las condiciones de desarrollo de insectos, bacterias y virus.

\section{Agradecimientos}

Consejo Nacional de Ciencia y Tecnología de México, Programa de Ciencia Básica, Convocatoria 2005, instancia que aportó los recursos para consultar los acervos de Guadalajara, Durango, Sonora, Puebla, Mérida, San Cristóbal de las Casas y Oaxaca. Los acervos de la Ciudad de México y Morelia fueron consultados gracias al apoyo de las administraciones del Instituto de Geografía-UNAM entre 2001 y 2009, así como, con la ayuda del programa ARCHISS-UNESCO (2001).

\section{Siglas}

Archivo del Antiguo Ayuntamiento de la Ciudad de México (AACM)

Actas de Cabildo de la Catedral de México (ACCM)

Archivo del Cabildo de la Catedral de Morelia (ACMM)

Archivo Histórico Municipal de Morelia (AHMM)

Archivo Histórico Municipal de Puebla (AHMP)

Archivo Histórico del Ayuntamiento de Guadalajara (AHAG)

Archivo del Cabildo de la Catedral de Guadalajara (ACCG)

Archivo Histórico del municipio de Oaxaca (AHMO)

Archivo Histórico de la Arquidiócesis de Antequera-Oaxaca (AHAO)

Archivo Histórico de la Arquidiócesis de Durango (AHAD)

Archivo Histórico y General del municipio de Durango (AHGD)

Archivo General del estado de Sonora (AGES)

Archivo Diocesano de San Cristóbal de las Casas (ADSC)

Archivo Histórico de la Arquidiócesis de Yucatán (AHAY)

Archivo General del Estado de Yucatán (AGEY) 


\section{Capítulo 1. Características de la documentación utilizada y sus tipos de información}

En el ámbito de la monarquía hispánica, los datos más precisos para lograr la reconstrucción de eventos climáticos, e incluso generar series climáticas, son los registros de las ceremonias de rogativa, asentadas en las actas de cabildo civil y eclesiástico de las sedes obispales, las cuales fueron diez, en lo que hoy día es territorio mexicano antes de 1810: México, Puebla, Valladolid (Morelia), Oaxaca, Guadalajara, Ciudad Real (San Cristóbal de las Casas), Mérida, Durango, Linares y Álamos. Las dos últimas sedes obispales fueron trasladadas a Monterrey y Culiacán, respectivamente, a lo largo del siglo XIX, dividiéndose la última en las diócesis de Sinaloa y Sonora en 1883.

La práctica de las rogativas a través de reliquias es de muy antigua tradición en el cristianismo, pero la disposición y dispersión de las habidas como botín de los cruzados, dio lugar a la consolidación institucional y popular de este tipo de ceremonia colectiva. A la fecha, buena parte de ellas son realizadas de manera comunitaria, alejadas de las instituciones, y la iglesia católica prácticamente ya no recurre a este tipo de ceremoniales. Su máximo apogeo institucional ocurrió durante el absolutismo Habsburgo y Borbón, y las primeras décadas de vida independiente de las repúblicas hispanoamericanas; asimismo, su conducción conllevaba serias implicaciones psicosociales, como catalizador del descontento social ante vicisitudes ambientales, socioeconómicas o políticas de envergadura.

De acuerdo con Mariano Barriendos (1997: 106) la institucionalización y generalización de las rogativas son acontecimientos de carácter renacentista, pero en el caso de algunas sedes obispales catalanas se comenzaron a llevar a cabo y asentar su gestión y realización desde mediados del siglo XV. El propio Barriendos nos recuerda que: "La relación entre instituciones religiosas y expresiones de cultura popular fue lograda por medio de estas celebraciones religiosas. La población contaba con canales por medio de los cuales podía demostrar sus preocupaciones y tensiones sociales, pero estos podían ser controlados por las autoridades eclesiásticas, dando lugar a situaciones en las que se evitaba el que acontecimientos que condujeran a disturbios, revueltas o incluso cambios sociales irreversibles 


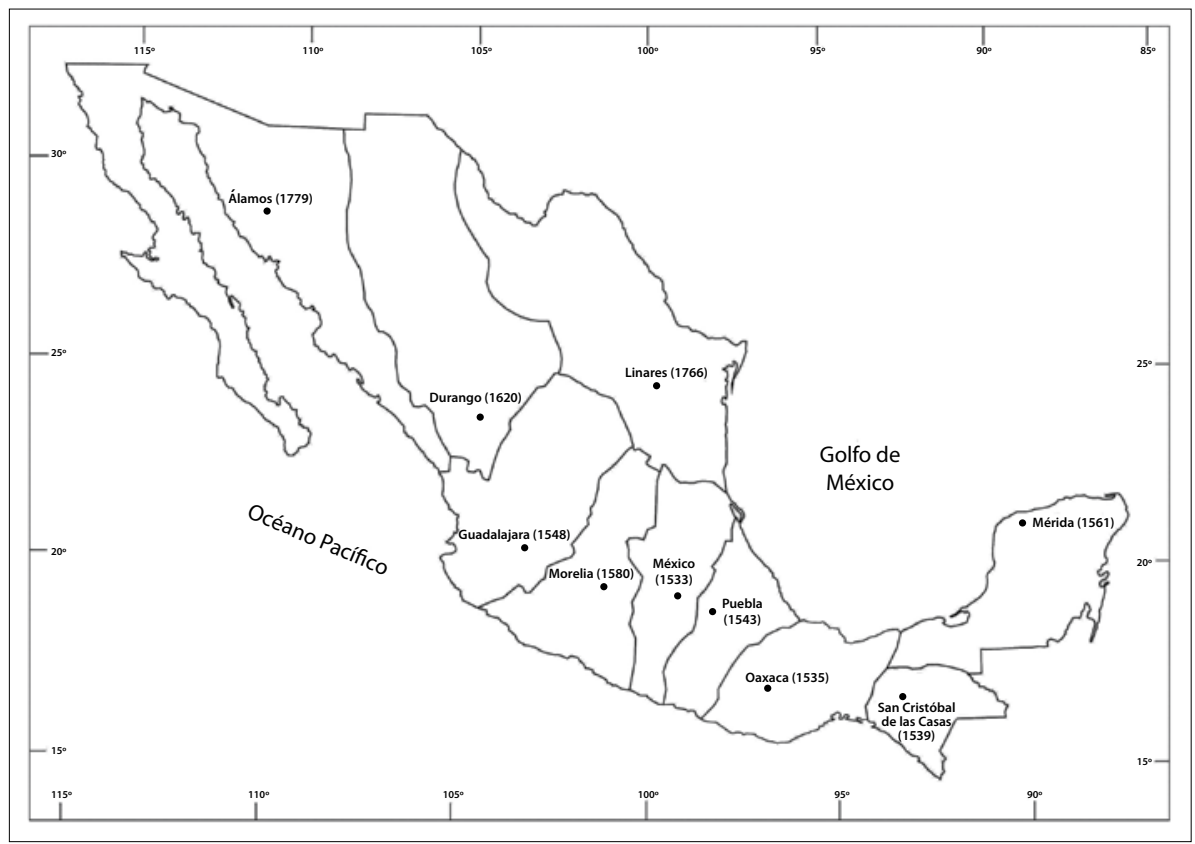

Figura 1. Localización de las sedes obispales novohispanas, sus límites y años en que fueron establecidas en las urbes que se refieren en esta figura.

tuviesen lugar. En el momento en que la población sabía que las demostraciones públicas tenían un formato invariable expresado de manera fija, los participantes implícitamente aceptaban la realidad social reinante..." (Barriendos, 2005: 386).

Por otra parte, el ya citado Javier Martín Vide, en coautoría con Mariano Barriendos (1995), aducen que la consolidación de los ceremoniales de rogativa como práctica institucional es, en buena medida, consecuencia de la contrarreforma católica, pero que fuera de cualquier consideración político-religiosa o administrativa, debe tomarse en cuenta que durante la alta Edad Media la ausencia de rogativas puede estar ligada al óptimo climático denominado Pequeño Óptimo Climático o Periodo Medieval Cálido. Desde esta perspectiva, puede asumirse que el ceremonial de rogativa pudo aumentar en número y pompa, como resultado de la irrupción de la PEH. La llegada de estas ceremonias a la América hispana se verifica bajo las condiciones climáticas de la $\mathrm{PEH}$ y las circunstancias político-militar y religiosa de la Europa de los siglos XVI y XVII. 
En la mayor parte de Hispanoamérica, la condicionante primordial para logar un óptimo abastecimiento de granos dependía de una o dos abundantes y prolongadas estaciones de lluvia. Ante tal necesidad de abastecimiento, sujeto a los vaivenes de la precipitación, las ceremonias pro pluvia eran el evento políticoreligioso más importante para lograr la supervivencia y viabilidad de la mayor parte de las urbes hispanoamericanas. Rituales que por su complejidad y costo sólo podían ser celebradas con todo su esplendor en las sedes obispales. Asimismo, existieron ceremonias conducidas de manera preestablecida y anual, para pedir por los buenos temporales y las buenas cosechas. Ceremoniales que se encuentran profusamente asentados en libros y documentos de los archivos civil y eclesiástico de las metrópolis españolas y de las órdenes religiosas.

Aunque los ceremoniales pro pluvia fueron los predominantes en lo hallado en los acervos del México central y meridional, existen algunos ceremoniales que pedían el apaciguamiento de los cielos, ceremonias pro serenitatem, que fueron llevadas a cabo en particular en México, Puebla, Guadalajara, Oaxaca y Durango. En el caso de la capital novohispana, es muy abundante la documentación de este tipo, especialmente como consecuencia de la prolongada inundación ocurrida entre 1627 y 1632, que incluso condujo a que se propusiera otro asiento para las sedes virreinal y arzobispal. En el caso de Puebla, aunque la urbe no se vio amenazada en su conjunto, los extremos en precipitación solían dejarla aislada, al derruirse puentes y obstaculizarse caminos. En los casos de Guadalajara, Oaxaca y Durango, los reportes del siglo XVII son muy dramáticos, ya que para entonces, las edificaciones de estas ciudades eran todavía muy endebles, y sus habitantes se encontraban a merced de terribles tempestades, habiendo sido más que comunes los decesos por rayos. Por detrás de las condiciones meteorológicas y sus extremos, dentro de las cuestiones ambientales, fueron las epidemias y los terremotos los eventos que impulsaron la realización de ceremoniales en rogativa. En Durango se localizaron los únicos documentos que hacen referencia a la necesidad de contar con un patronazgo (en este caso San Jorge) en contra de los alacranes y otros animales ponzońosos (AHAD, Libro VII; 1748-1751, 11-II-1749).

Las rogativas por epidemia eran conducidas por lo general a escala local, aunque existen extractos que hacen referencia a peticiones por la población de otras ciudades y puertos, en particular Veracruz. Fue común en el discurso de estas rogativas pedir para que dicha amenaza no llegase a la localidad donde se estaban realizando tales ceremoniales. La única referencia hallada con respecto a condiciones ambientales fuera de la Nueva España, la grave situación que se vivió en Andalucía hacia 1805; tan terrible debió ser la circunstancia en el sur de España, que dio motivo a la realización de sendos ceremoniales en Gua- 
dalajara y Puebla (ACCG, Libro 12-I; 1805, 6-V-1805); AHMP, Libro 74; 1805, 17-I-1805).

Cabe hacer hincapié que las instituciones creadas en Hispanoamérica tenían en la conducción del ceremonial en rogativa (por parte de las autoridades civiles y religiosas), en el abastecimiento de agua y alimentos y en la defensa de la ciudad, las únicas funciones en que los gobiernos locales se involucraban para garantizar la supervivencia de los súbditos de la monarquía. Instituciones que hasta la década de 1590 lograron en la capital novohispana implementar un aparato administrativo que diese lugar al registro continuo y al desarrollo de ceremoniales, con la misma pompa con que se realizaban en España, tal y como demuestra el siguiente extracto procedente del ayuntamiento de México: “... Para tratar y determinar necesario ordenar un maestro de ceremonias en esta Santa Iglesia, como los habidos y acostumbrados tener en las catedrales de Espańa, quedó resuelto y acordado por la mayor parte que se suspenda por ahora el nombrar el dicho oficio y que no se trate de él, hasta que el señor Arzobispo que se aguarda, venga..." (ACCM, Libro 4; 1589-1605, 11-VIII-1595).

Tal madurez político-administrativa también tuvo un reflejo en lo material, siendo por aquel pasar del siglo XVI al XVII cuando las iglesias de las principales advocaciones de la cuenca de México comenzaron a ser reedificadas con materiales más perdurables y de mucha mayor gala las naves, cúpulas y torres logradas (ACCM, Libro 4; 1589-1605, 29-VIII-1600). En términos culturales, comenzaba la rivalidad entre la figura traída por los españoles (la virgen de Los Remedios, talla a la que se recurría ante la amenaza de extrema sequedad y con menor frecuencia ante fuertes hielos) y la virgen de Guadalupe (cuyo patronazgo en términos ambientales fue utilizado para pedir el remedio de las inundaciones que tan frecuentemente asolaron a la capital de la Nueva España), aparecida en estas tierras. Rivalidad que fue asumida entre el cabildo civil como patrono de la primera y el cabildo eclesiástico, patrono de la segunda. Por tanto, en las actas del cabildo civil de México abundan referencias con respecto a la virgen de Los Remedios, mientras que en el cabildo eclesiástico proliferan los documentos con respecto al culto guadalupano. Una particularidad del culto a la virgen de Los Remedios es la lejanía del santuario con respecto al primer cuadro de la Ciudad de México, poco más de quince kilómetros. Distancia inusual para un santuario en la península ibérica e Iberoamérica, pero el hallazgo de la talla años después de la huida de Hernán Cortés de México-Tenochtitlan, en donde de acuerdo con la leyenda, el mismo la había extraviado, determinaron la localización del santuario en tan escarpada zona. A partir de 1574 el santuario quedó bajo la potestad del 
ayuntamiento capitalino (AACM, vol. 637a; 1571-1584, s/f) como enclave dentro de la jurisdicción de Tacuba.

La incidencia de las inclemencias meteorológicas en la viabilidad de la urbe preindustrial queda manifiesta, en la realidad cultural católica, en el uso de diversas advocaciones para pedir buenos temporales y buenas cosechas, así como que la ciudad no fuese víctima de capítulos meteorológicos que pudiesen poner entredicho la existencia de la propia urbe. Así, además de las ceremonias de rogativa conducidas ante los azotes de la naturaleza, se realizaban ceremoniales anuales preestablecidos que eran celebrados con las mismas advocaciones utilizadas ante las urgencias o con otras veneraciones a las que se recurría sólo con este fin. Ejemplo de ello fueron en la capital novohispana, las ceremonias establecida a san Gregorio Taumaturgo, como 'abogado' de la ciudad contra las inundaciones (ACCM, Libro 5; 1606-1616, 26-X-1607) o san José, como protector contra rayos y terremotos (Biblioteca Nacional-Fondo Reservado, Manuscritos 779; AHMP, vol. 14; doct. 280, 188v-189f, 13-VIII-1611).

En algunos casos, las advocaciones elegidas contra las diversas adversidades ambientales perduraron a lo largo del período virreinal hasta las primeras décadas de vida independiente. Pero en algunas sedes obispales, las terribles condiciones climáticas de buena parte del siglo XVIII hicieron que se tuviera que recurrir a otros lienzos, tallas o crucifijos con la finalidad de enfrentar tan adversas condiciones. Así, por ejemplo, la virgen de Guadalupe comenzó a mediados del siglo XVIII a ser la figura principal de un ceremonial pro pluvia que se llevaba a cabo cada primavera (Biblioteca Nacional-Fondo Reservado, Manuscritos 780). Por su parte, la capital michoacana pidió por la lluvia con ceremonias y procesiones que encabezaban crucifijos también hasta mediados del siglo XVIII, pero lo severo de las anomalías que empezaron a ocurrir por aquel entonces hicieron necesario contar con una advocación (virgen de Los Urdiales) a la que se recurriese exclusivamente por causa de la extrema escasez de lluvia (ACMM, Libro XXI; 1748-1751, 15-VII-1749).

Hasta aquí se ha mencionado el uso de las ceremonias de rogativa contra las adversidades dictadas por la variabilidad climática, pero el abanico de asuntos que merecían la realización de este tipo de ceremoniales abarcaban desde terremotos, plagas y epidemias hasta cuestiones de la vida privada de la casa reinante. La práctica de la rogativa era uno de los mecanismos más útiles de control social que el Estado y la Iglesia podían lograr, y su conducción significaba catarsis colectiva, así como la pervivencia de marcados intereses económicos, militares y políticos.

A partir de los cientos de extractos resguardados y consultados en México, Puebla, Morelia, Durango, Guadalajara y Oaxaca, se resumen las temáticas 
abordadas por los ceremoniales en rogativa, fuera de los generados por causas ambientales: a) prosperidad del Estado y la Iglesia; b) guerras de España (oración que se denominaba pro tempore belli); c) salud de monarcas, obispos y virreyes (en la etapa republicana por la salud del presidente o su esposa); d) embarazos y alumbramientos de la reina; e) para que el obispo electo a ocupar una sede vacante resultase un buen pastor; f) para que los viajes de obispos y virreyes fueran buenos; g) por la salud del papa y por su gobierno en Roma; $h$ ) expediciones a Sonora y California en el siglo XVIII; I) por causa de los ataques de los piratas e invasiones a los puertos del golfo de México y el mar Caribe; j) por elecciones en paz durante la época republicana, así como por una buena legislatura; $\mathrm{k}$ ) por un buen gobierno del presidente de la república; l) por las guerras con Francia y los Estados Unidos; m) contra la revolución de Ayutla y el bando liberal durante la guerra de Reforma y, por último, a favor del imperio de Maximiliano, tanto por las negociaciones emprendidas en Europa, por el viaje de la pareja imperial, como por los triunfos político-militares de este efímero régimen.

De las temáticas ajenas a la variabilidad climática y virulencia epidemiológica, llaman particularmente la atención las ceremonias de rogativa conducidas por los conflictos político-militares de España con otras potencias y la cuestión de Estado que significaba la continuidad de la casa reinante. El consultar las actas de cabildo civil y eclesiástico de las principales urbes novohispanas permite, en una duración prolongada, reconstruir las prioridades políticas e incluso económicas de la Monarquía Hispánica en su escala imperial. La guerra de sucesión española de principios del siglo XVIII y la invasión napoleónica fueron los dos eventos bélicos que más registros de rogativa generaron antes de las guerras de independencia. En el caso de la primera se puede dar cuenta de diez ceremoniales, llevados a cabo enMéxico, Morelia y Durango entre 1699 y 1713. En cuanto a las guerras napoleónicas, estas dieron lugar al registro de quince ceremoniales, conducidos en México, Morelia, Puebla, Oaxaca y Durango entre 1808 y 1815.

Antes de avanzar hacia los registros de las ceremonias de rogativa durante las guerras de independencia y el México independiente, no se pueden dejar de mencionar, por su importante reflejo económico, los ceremoniales que se convinieron para que la flota anual llegase con bien a España, y en su viaje de vuelta a La Habana y Veracruz. Tan relevantes resultaban tales viajes a la monarquía, como a las autoridades novohispanas, que entre 1631 y 1778 se encontraron en archivos de México, Puebla, Morelia y Oaxaca, cuarenta ceremonias por el bienestar de la flota: la primera fue asentada por el ayuntamiento de Puebla, el 26 de septiembre de 1631 (AHMP, vol.17; doct. 279, 288f-297v) y la última el 9 de enero de 1778, por parte del cabildo civil de la Ciudad de México. 
Los ceremoniales de rogativa conducidos durante las guerras de independencia son en su totalidad de signo realista, siendo el primer ceremonial concerniente a enfrentamientos militares en la Nueva España, consecuencia de la ocupación insurgente de Valladolid de Michoacán y fue asentada el 6 de octubre de 1810 (ACMM, Libro XLIII; 1807-1811). Aparte de este registro se hallaron catorce más en México, Morelia, Guadalajara y Oaxaca; cabe señalarse que tanto el episodio bélico de la sierra de Las Cruces (ACCM, Libro 65; 1810-1811, 30-X-1810), como la ocupación insurgente de Guadalajara (AHAG, Libro XVI; 1809-1824, 23-III1811), quedaron referidos por medio de sendos ceremoniales en rogativa.

Una vez consumada la independencia, los ceremoniales de rogativa fueron pieza clave en la legitimización del nuevo régimen. Prueba de ello fue su inmediata utilización para solicitar: “... el Divino Auxilio para que el establecimiento del nuevo gobierno se verifique con acierto, acuerdo y tranquilidad...” (ACMM, Libro XLVII; 1819-1821, 5-IX-1821). La adecuación de los ceremoniales de rogativa a la vida independiente y el papel destacado de las advocaciones regionales en esta reconversión cultural, así como el compromiso de que este tipo de ceremoniales sean parte de la vida institucional a futuro, quedan claramente asentados en el siguiente extracto: "Siguiendo pues la opinión pública, pido al Ilustre Ayuntamiento que para inmortalizar la memoria del venturoso trece de junio de 1821 (proclamación de la independencia en Jalisco), se sirva excitar el celo del señor jefe político para que se reúnan todas las corporaciones de esta nobilísima ciudad; y con solemnidad y magnificiencia propia del acto se jure y proclame a nuestra enunciada madre María Santísima de Zapopan por generala de las armas del ejército de Nueva Galicia... comprometiéndose a solemnizar en los venideros años tan plausible día con misa y panegírico...” (ACCG, Libro 18; 1821, 9-VII-1821).

$\mathrm{El}$ asiento y correctas deliberaciones de las cortes y posteriormente congreso de la república, así como el que el gobierno por establecerse fuese benéfico a la nación, fue motivo de ceremonias de rogativa a lo largo de la vida republicana hasta la década de 1850; la primera encontrada corresponde al 3 de noviembre de 1821 (AHAD, Libro XXI; 1820-1824) y la última al 2 de febrero de 1856, habiendo sido localizados veintitrés documentos de este tipo en México, Oaxaca, Puebla y Morelia. Asimismo, las elecciones para el congreso o elegir al presidente de la república motivaron la realización de ceremoniales de rogativa, aunque estas solo fueron tres, una en Oaxaca y dos en la Ciudad de México.

La inestabilidad político-militar del México independiente antes del porfiriato queda manifiesta en la cantidad de ceremoniales de rogativa conducidos con el fin de lograr la paz, aminorar los estragos de las guerras o la derrota del enemigo, ya fuese externo o interno. Entre los extractos correspondientes a este 
período se puede destacar: 1) que a pesar de su corta duración el imperio de Agustín de Iturbide, tuvo de tiempo de que se hiciesen rogativas públicas por su establecimiento y "feliz gobierno", así como por el parto de la emperatriz y el que el emperador tuviese fortuna en su viaje a la provincia de Veracruz (AHAD, Libro XXI; 1820-1824, 23-XI-1822 y ACMM, Libro XLVIII; 1822-1824, 4-VI-1822).

2) Las rogativas por situación política del país motivaron la realización de nueve ceremoniales entre las décadas de 1830 y 1860, conducidas en Puebla, México y Guadalajara. 3) Las invasiones extranjeras fueron particularmente traumáticas, y esto se hizo patente en el número de rogativas llevadas a cabo: la guerra de los Pasteles motivó sólo tres ceremoniales (en México, Puebla y Morelia), mientras que la invasión norteamericana fue motivo de dieciocho manifestaciones públicas de la Iglesia (en México, Guadalajara, Morelia, Puebla y Culiacán -extracto localizado en Hermosillo-). 4) En cuanto a la revolución de Ayutla, se localizaron dos registros de este tipo de ceremonias y cinco de la guerra de Reforma (en México y Guadalajara).

La guerra de Reforma y la eventual aplicación de las leyes homónimas significó el fin de la responsabilidad gubernamental en la corresponsabilidad y financiamiento de los ceremoniales de rogativa. Aunque los desencuentros entre cabildos de ayuntamientos y catedrales había comenzado mucho antes, al menos desde las reformas borbónicas, ya desde la década de 1830 la presencia de miembros del partido liberal en los ayuntamientos había tensado mucho la relación entre autoridades civiles y eclesiásticas. Con respecto al patronazgo más importante del país, el que la Ciudad de México tenía en la Virgen de los Remedios, en 1862 se resolvió la situación en los siguientes términos: "Siendo el Ayuntamiento de México el dueño de la fábrica material del santuario de Los Remedios, con sus casas anexas, las deja al servicio del templo, mientras esté abierto al culto público, conservando el capellán el derecho de usufructo y habitación que ha tenido hasta aquí... Conserva el capellán las propias facultades que hasta ahora ha ejercido para la inspección de los lotes de terreno, repartidos entre los vecinos..." (AACM, 184-A; 1862, 10-XII-1862).

La intervención francesa y el imperio de Maximiliano fueron una última bocanada para las manifestaciones públicas de la Iglesia con el respaldo de las autoridades locales y del Estado. A principios de 1864 se le restituyó su salario al capellán de Los Remedios (AACM, 187-A; 1864, 29-III-1864), y entre 1864 y 1866 se asentaron en México y Morelia rogativas por el feliz viaje del Emperador (ACCM, Libro 86; 1861-1865, 12-IV-1864), por tener éxito en las negociaciones entre el nuncio apostólico y el Emperador (ACCM, Libro 86; 1861-1865, 2-XII1864), por la salud de la Emperatriz (ACMM, Libro LXV; 1864-1867, 26-X-1866), 
y por supuesto a favor de las armas invasoras (ACMM, Libro LXV; 1864-1867, 7-XII-1864). Después de 1867 las rogativas no iban más allá de los atrios de las iglesias y las ceremonias dejaron de ser en lo primordial novenarios, para convertirse en triduos, celebraciones de sólo tres días: adecuación de la liturgia a las condiciones político-religiosas impuestas por el triunfante partido liberal.

\section{Niveles de rogativa e intensidad de las anomalías climáticas}

Una característica relevante del tipo de información que contienen los registros de ceremoniales de rogativa es que se conducían de acuerdo con la gravedad de las circunstancias y el grado de elaboración de las ceremonias y traslados de las imágenes respondía a ello. Para Mariano Barriendos (Garza y Barriendos, 1998) se pueden distinguir cinco grados de ceremoniales de acuerdo con las formas como se conducían les rogatives en Cataluña desde el siglo XV. En la Nueva España, los ceremoniales difirieron de los castellanos y aragoneses, pero la cuantificación propuesta por Barriendos es apreciable de acuerdo con los diversos grados de elaboración e inclusión de actores económicos, políticos y sociales conforme más cruenta fuese la situación. Las características de estos niveles se explican con lo acontecido en la Ciudad de México y registrado con riguroso detalle por su ayuntamiento entre 1641 y 1642. El año de 1641 debió ser bastante cruento, lo que motivó a realizar en la capital novohispana, a mediados del mes de junio, un ceremonial que por su elaboración se propone de nivel V (véase infra). El siguiente invierno posiblemente muy seco, suscitó la preocupación de las autoridades, y tan pronto en el año, como fines de marzo, comenzaron a realizar rogativas de diversos niveles hasta mediados de mayo, cuando realizan una de nivel IV. La cual no fue la última en el año, ya que el 11 de agosto se asentó una de nivel III y el 29 de ese mismo año, una de nivel V (AACM, 664a; 1640-1643):

Nivel I. Estas rogativas pro pluvia se llevaban a cabo con rezos en silencio al interior de las iglesias, pero la liturgia hacía referencia a la necesidad de las lluvias: "El señor alcalde don Cristóbal de la Mota, dijo que es notorio la falta de salud y aprietos con que se haya esta ciudad y propone a la ciudad se pida a la Santa Iglesia Catedral y demás religiones se hagan rogativas particulares, pidiendo a Nuestro Señor se sirva socorrer a esta ciudad..." (AACM, vol. 664a; 1640-1643, 29-III-1642).

Nivel II. Esta rogativa se sigue realizando al interior de la Catedral, pero en ella ya participa el gobierno de la ciudad, la presencia de feligreses acom- 
pañando al ayuntamiento era el primer paso de participación colectiva ante una urgencia ambiental: "El señor don Pedro de la Barrera, dijo que su excelencia lo llamó y hallándolo con el cuidado que acostumbra dio recaudo para que esta ciudad pidiese en la Santa Iglesia Catedral y demás conventos se hiciese rogativa por la salud pública y buenos temporales y que en esta conformidad se hizo queda cuenta a la ciudad...” (AACM, vol. 664a; 1640-1643, 9-V-1642).

Nivel III. Este ceremonial echa mano, ante la intensificación de la anomalía climática, de la patrona jurada por los buenos temporales y se trata de nueve días de ceremonias: "Mucho nos aprieta como vuestra señoría ve las necesidades y trabajos que estos días representa con las enfermedades, hambre, falta de lluvias y otros malos sucesos y aunque estoy cierto del fervor y devoción grande con que todos han acudido por su parte suplicando a Nuestro Señor sea servido de usar con nosotros de su excelencia y misericordia, todavía cuando estas santas diligencias más se continúan y se multiplican tanto más, debemos esperar recibir la gracia colmada y así me ha parecido proponer al cabildo de esta Santa Iglesia que se haga novenario de misas cantadas en la ermita de Nuestra Señora de los Remedios..." (AACM, vol. 664a; 1640-1643, 15-V-1642).

Nivel IV. La ceremonia que culmina el novenario puede considerarse una rogativa de nivel IV al incluir una procesión en las proximidades de Los Remedios: “... en conformidad del acuerdo de la ciudad fue con el señor don Juan de Orduña a besar la mano de su excelencia, como se le dio de que la ciudad había resuelto comenzar el novenario en la ermita el sábado y que el domingo que viene, iba el cabildo eclesiástico a cantar la misa y hacer la procesión y rogativa y su excelencia estimo el cuidado de la ciudad...” (AACM, vol. 664a; 1640-1643, 19-V-1642).

Nivel V. El ceremonial más elaborado incluía la participación de ambos cabildos (civil y religioso), de todas las órdenes religiosas y prácticamente de la ciudad entera, y consistía de una procesión desde el santuario de la virgen de Los Remedios (como ya se ha dicho, a 15 kilómetros al noroeste de la capital, en el actual municipio de Naucalpan, estado de México) hasta la iglesia de la Santa Veracruz (costado norte de la alameda capitalina), donde pernoctaba la imagen, y de nuevo en procesión era trasladad a la catedral, donde se le hacía un novenario: “... su excelencia ordena que atento a la mucha seca que hay y daños que de ella resultan y a la devoción que esta ciudad tiene a la Virgen de los Remedios se traiga en procesión, como se ha hecho otras veces... 
mediante las necesidades presentes se traiga la Santísima imagen el domingo que viene, diecisiete de este y para que se confiera con el cabildo de la Santa Iglesia Catedral la forma de la traída y que sea con la decencia que se requiere...” y “... la traída de la Santísima imagen fuese el jueves trece de este por la tarde, respecto de que la necesidad apretaba y que de la Santa Iglesia saldría la procesión con todas las religiones y cofradías hasta la parroquia de la Santa Veracruz y que la Santísima Virgen habría de estar el novenario en el altar mayor..." (AACM, vol. 664a; 1640-1643, 10-VI-1641 y 16-VI-1641).

Estos niveles de ceremoniales también se reconocen en las ciudades de Morelia, Puebla, Oaxaca, Mérida, Guadalajara y Durango; las tres primeras tuvieron sus santuarios dentro de la misma ciudad o a lo mucho en sus extramuros, mientras que las tres últimas tuvieron sus santuarios eventualmente más socorridos alejados de la urbe, siendo el caso más extremo, en distancia, el de Mérida, donde las vicisitudes más apremiantes eran enfrentadas bajo el manto protector de la virgen de Izamal, cuyo santuario se localiza a más de 60 kilómetros de la capital yucateca. Por supuesto, ningún ceremonial fue tan elaborado como los ocurridos en la capital novohispana.

\section{Las anomalías y el abasto desde otras comarcas y regiones}

Ahondar en la posibilidad de abasto de granos en el mundo preindustrial se hace indispensable, en tanto que la necesidad de realizar ceremonias de rogativa por buenos temporales y cosechas se basaba en buena medida en la imposibilidad de transportar grandes volúmenes de alimentos de una región a otra, siendo el radio de alcance de las urbes relativamente limitado. Al consultarse las actas de cabildo de ayuntamientos y catedrales es una constante, ante condiciones climáticas adversas, la referencia a las comarcas que podían ser útiles ante la escasez de alimentos. En los alrededores de las ciudades de México y Puebla el componente climático-altimétrico es muy evidente, al reconocerse que la cuenca alta del Lerma (valles de Ixtlahuaca y Toluca) y los valles de Chalco eran adonde se recurría en caso de una pérdida generalizada de granos. Por su altitud y relieve estos valles manifiestan una menor evapotranspiración, factor favorable a la agricultura, en caso de escasez extrema de precipitación en los altiplanos meridionales de México. 
La relevancia de las comarcas de Chalco y Toluca, y la posibilidad de lograr cosechas, aunque pudiesen ser magras, cuando en el resto de las cuencas de México y el alto Lerma se llegaban a perder del todo, queda descrito en los dos siguientes extractos: "El señor marqués dijo que el motivo que tiene para celebrar este cabildo y haber enviado llamar a dichos señores, es que como es notorio, las cosechas de maíces de Chalco y Toluca fueron muy escasas, que en las demás partes del todo se perdieron y para sustentarse hay mucha seca y ha de haber más en dichos parajes, que todo ha de hacer gran falta para sustentar esta ciudad..." (AACM, vol. 665a; 1706-1713; 6-XII-1713). Y:

Dijo que se haya con noticia de que por haberse perdido la cosecha de maíces, tierra adentro, se están sacando muchas porciones de Toluca y de Chalco, que necesariamente han de hacer falta para proveer esta república... se pregone en Chalco no se saque maíz para otra parte que para esta ciudad... (AACM, vol. 52-A; 1726, 22-XI-1726).

Como se sostuvo con anterioridad, la relevancia que las ceremonias de rogativa tenían como mecanismo de control político y social era, en parte, causa de la imposibilidad de abastecer una urbe con productos localizados a distancias mayores a cien kilómetros. Ejemplo de ello nos lo brinda el siguiente extracto:

Viose una representación que a su excelencia hace el señor oidor... proposición para poder sacar de doce a quince mil fanegas de maíz de los valles de Toluca y Metepec, para los lugares de San Juan del Río, la villa de León, Guanajuato, el Mezquital, Pachuca y otras sobre que su excelencia se sirva mandar a esta nobílisima ciudad... y que los lugares donde se matricularon dichos maíces son muy distantes y con la seca que se padece, hay falta de pastos y aguas por las recuas cuya dificultad se pulsa y que sólo el maíz que se tiene por cierto y fijo es el de Chalco, Toluca y Metepec... (AACM, vol. 667a; 1714-1719, 28-V-1714).

En cuanto a las cuestiones tocantes a la producción de granos y el abastecimiento de estos en las urbes, y su correlación con la trayectoria climática, la historiografía dedicada a la vida económica ha dado buena cuenta de estas temáticas. Aproximaciones desde esta vertiente del conocimiento (Tortolero, 1996; Florescano, 1976, 1995), buscaron adentrarse en la variabilidad climática a través de las fuentes documentales que tratan sobre producción y abastecimiento de granos. Sin embargo, este tipo de información puede resultar imprecisa, tanto por intereses económicos y políticos, como por un desfase temporal con respecto 
al evento climático. Asimismo, se trata de información cuyos registros no son continuos y prolongados en el tiempo, ni los documentos son siempre firmados por varios individuos, como sucedía con las actas de cabildo.

Una vez explicado el tipo de documentos utilizados para esta clase de pesquisa, los sitios donde se resguardan y las características que manifiestan, se ha procedido a desglosar la información recabada en cuatro capítulos que se han organizado de acuerdo con la cantidad y continuidad de la misma, así como por su localización. Así se tiene un primer capítulo que resume y contrasta los datos encontrados en la Ciudad de México, Puebla y Morelia, que son las ciudades que brindan la oportunidad de generar las series climáticas más prolongadas y continuas en México. La comparación de sus datos permite vislumbrar, como a pesar de su relativa cercanía, su proximidad a uno u otro océano, puede dictar diferencias en las formas en que se manifestaron las diversas anomalías climáticas ocurridas entre fines del siglo XVI y fines del XIX.

Al capítulo dedicado a las tres urbes arriba mencionadas, le sigue uno que trata sobre Guadalajara y Oaxaca y se compara lo obtenido en estas ciudades con lo manifestado en el centro del país, dada su relativa cercanía a este y con la idea de calibrar la escasa información obtenida en las capitales de capitales de Jalisco y Oaxaca. El cuarto capítulo muestra los datos proveniente de Durango y Sonora, mientras que el quinto capítulo versa sobre lo indagado en Mérida y San Cristóbal de las Casas. Por último, este trabajo se concluye con un anexo en el que se sintetizan los datos obtenidos en nueve de las diez sedes obispales existentes en el país antes de la independencia. 



\section{Capítulo 2. México, Puebla y Morelia}

La documentación encontrada en las ciudades de México, Morelia y Puebla, es la más abundante y adecuada para las finalidades de este tipo de pesquisa. Asimismo, su relativa proximidad invita a tratarlas de manera conjunta, ya que a grandes rasgos su régimen climático es similar, con la salvedad de que Morelia está más influenciada por eventos provenientes del océano Pacífico, y Puebla, en lo particular en la mitad seca del año, puede verse influida por eventos desde el golfo de México: la integración de la información de tres urbes permite consolidar, desde las fuentes documentales, el conocimiento sobre la variabilidad climática entre los siglos XVII y XIX sobre la parte central del Eje Neovolcánico, lugar de residencia en la actualidad de más de 32000000 de personas (INEGI, 2010).

Para comprender la forma como se definen las series climáticas propuestas, se considera indispensable detallar la manera en que se conduce este tipo de investigación: en primera instancia, se deben consultar todos los volúmenes de las actas de cabildo civil y eclesiástico, desde el inicio de su registro hasta que se dejen de asentar las ceremonias de rogativa en ambos acervos, o de manera explícita se establezca la separación Iglesia-Estado en documentos hallados en los cabildos civiles. Las actas de cabildo del ayuntamiento de la Ciudad de México (AACM) son las más antiguas, ya que su registro comenzó en 1524, apenas asentada la sede de poder político y religioso español sobre la traza de México-Tenochtitlan. Por su relevancia histórica, entre los años de 1524 y 1643, las actas de este cabildo se encuentran impresas, teniéndose que recurrir al material original a partir del año 1697 y hasta el de 1866, año en el que se suspendió la consulta. Desafortunadamente, las actas de 1644 a 1691 se quemaron en el incendio del palacio virreinal, ante el desabastecimiento de alimentos provocado por las anormales circunstancias climáticas del año del chahuixtle (1691), caracterizado por la persistencia de nublados que provocaron la aparición de hongos en los cultivos de granos. En el acervo del antiguo ayuntamiento de México tampoco existen los registros de los cinco años subsecuentes al del chahuixtle, ni los años de 1807 y 1853 . El número de volúmenes consultados fue de 178 .

Las actas del ayuntamiento de Puebla fueron las segundas en haber comenzado su registro en la Nueva España (1534). La consulta se realizó en discos 
compactos proporcionados por el Archivo Histórico Municipal de Puebla (AHMP), con información entre 1534 y 1695, y en material original entre 1695 y 1856, año en que cesó la consulta. Los faltantes son únicamente los volúmenes correspondientes a los años de 1784, 1785 (curiosamente el año del hambre, como se le conoció en el México central de fines del siglo XVIII), y 1820, cuyo volumen existe pero se encuentra restringido por hongos. En este acervo el número de volúmenes consultado fue de 123 . En este punto cabe señalar que no se ha llevado a cabo la consulta del archivo histórico de la catedral de Puebla debido a las difíciles y limitadas condiciones de consulta de este acervo.

En tercer lugar, por la antigüedad de sus registros, se tiene a las actas de cabildo de la catedral de México (1536), cuya consulta se realizó en el Centro de Estudios de Historia de México (antes Condumex, ahora Carso), resguardas en microfilm. Se consultaron desde la primera acta hasta 1873, teniéndose como únicos faltantes los años entre 1559 y 1568 en el libro 2 (1559-1576), los años que van de 1702 a 1705 en el libro 26 (1702-1709); y tampoco existen registros entre 1858 y 1869 , y no se celebraron cabildos entre el 18 de junio de 1867 y el 23 de abril de 1868. El número de volúmenes contenidos en el mencionado microfilm es de 89.

Las actas de cabildo de la catedral de Morelia comenzaron su registro en 1586 y su consulta se prolongó hasta 1891, ya que para 1884 todavía se asentó una rogativa pro pluvia en este acervo, y 1891 es el año en que comienzan los registros por medio de instrumentos meteorológicos en la capital de Michoacán. Los únicos faltantes en este rico acervo corresponden a los años de 1800 y 1801. El número de volúmenes revisados fue de 70 . Por su parte las actas de cabildo de la antigua Valladolid de Michoacán tuvieron un cuidado bastante precario en su registro y continuidad, lo que limitó su consulta de 1735 a 1854. Aunque existen algunos extractos correspondientes al siglo XVII y principios del XVIII, el primer volumen que corresponde a unas actas de cabildo asentadas en forma corresponde al libro 21 (1735-1741).

La pobreza administrativa del cabildo civil de Valladolid puede adjudicarse a lo que Oscar Mazín (1996: 138) aduce sobre la injerencia de la Iglesia en la fundación y viabilidad urbana de Valladolid: "A principios del siglo XVII la sede del obispado, con todo y su valle, apenas sobrepasaba los 2,000 habitantes... a partir de 1585. El alcalde mayor de Michoacán volvería a residir en Pátzcuaro, al menos por temporadas cada ańo. Los miembros del ayuntamiento, aunque nominalmente domiciliados en Valladolid, estaban ausentes de sus cargos la mayor parte del tiempo atendiendo negocios en sus fincas rurales... A pesar de sus graves problemas parecía que la Iglesia tendría que tomar la iniciativa y levantar una 
ciudad en torno a sus altares." El número de volúmenes consultados en este corto e impreciso acervo fue de 40.

Una vez acotada la duración de las consultas, se resume la temporalidad de las cinco series climáticas generadas a partir de un registro continuo de las ceremonias de rogativa en los cinco acervos consultados. Aunque existen antecedentes de procesiones asentadas en las actas de cabildo durante el siglo XVI y principios del XVII, no es hasta que se registran con detalle la intervención de gremios $\mathrm{u}$ actores sociales y la correspondencia entre cabildos, que las ceremonias de rogativa por grado de institucionalidad y participación colectiva se convierten, para quienes buscamos reconstruir el clima pretérito, en una fuente fehaciente de información:

1. Archivo del Antiguo Ayuntamiento de la Ciudad de México (AACM): la ceremonia pro pluvia que inicia la serie climática propuesta, comienza con un ceremonial de nivel V, asentado el 16 de agosto de 1597 (AACM,

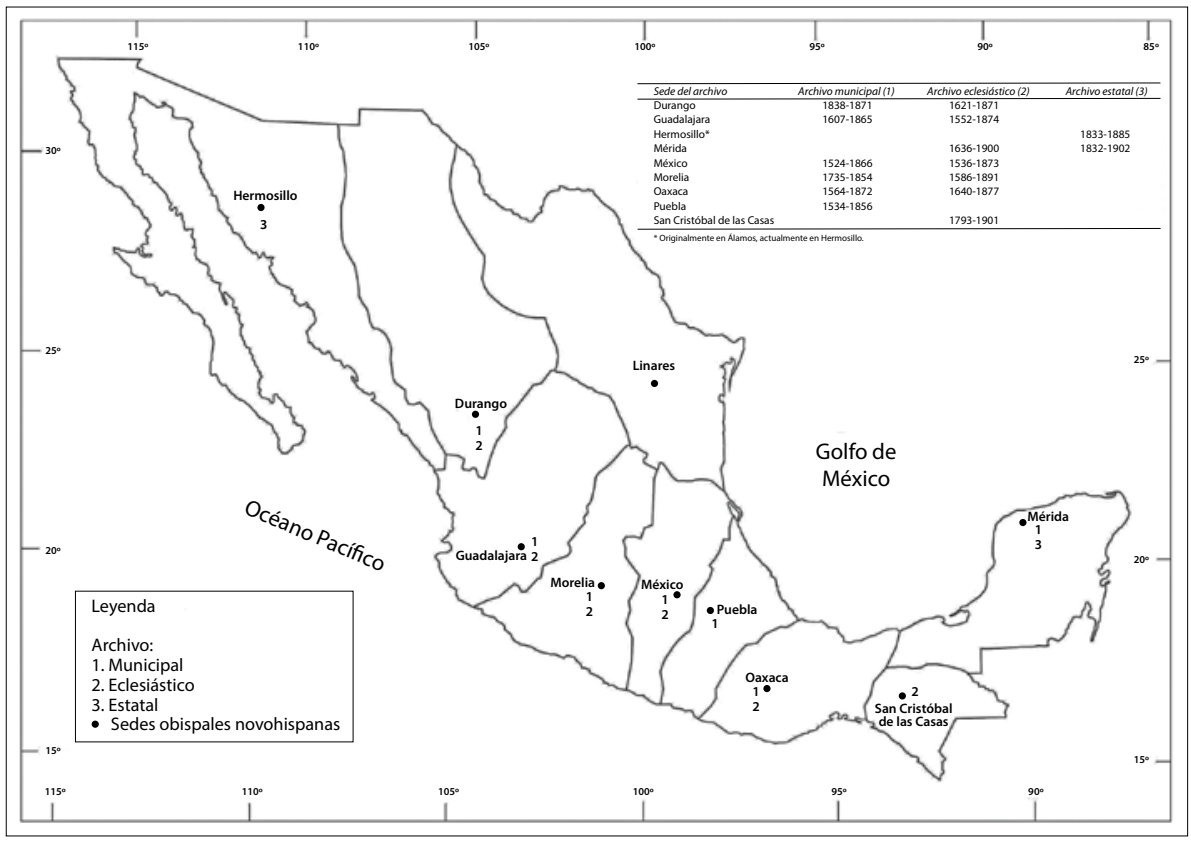

Figura 2. Mapa que muestra la cronología de las consultas de las actas de cabildo civil y eclesiástico de nueve ciudades en México. 
vol. 643a; 1597-1599), y termina el 31 de mayo de 1859 (AACM, vol. 180A; 1858-1859).

2. Actas de Cabildo de la Catedral de México (ACCM): la ceremonia pro pluvia que dio comienzo a esta serie se asentó el 19 de junio de 1609 (ACCM, Libro 5; 1606-1616), y se cerró con un ceremonial pro pluvia asentado el 31 de agosto de 1856 (ACCM, Libro 85; 1854-1857).

3. Archivo del Cabildo de la Catedral de Morelia (ACMM): registra una primera rogativa pro pluvia el 17 de septiembre de 1632 (ACMM, Libro III; 1626-1634), y tiene como último ceremonial pro pluvia uno asentado el 13 de julio de 1884 (ACMM, Libro LXIX; 1881-1887).

4. Archivo Histórico Municipal de Morelia (AHMM): el terrible año de 1739 provocó el primer registro de ceremonia de rogativa pro pluvia el 9 de julio (AHMM, Libro 21; 1735-1741), habiendo sido asentado el último ceremonial de este tipo el 17 de junio de 1854 (AHMM, Libro II-35; 1854).

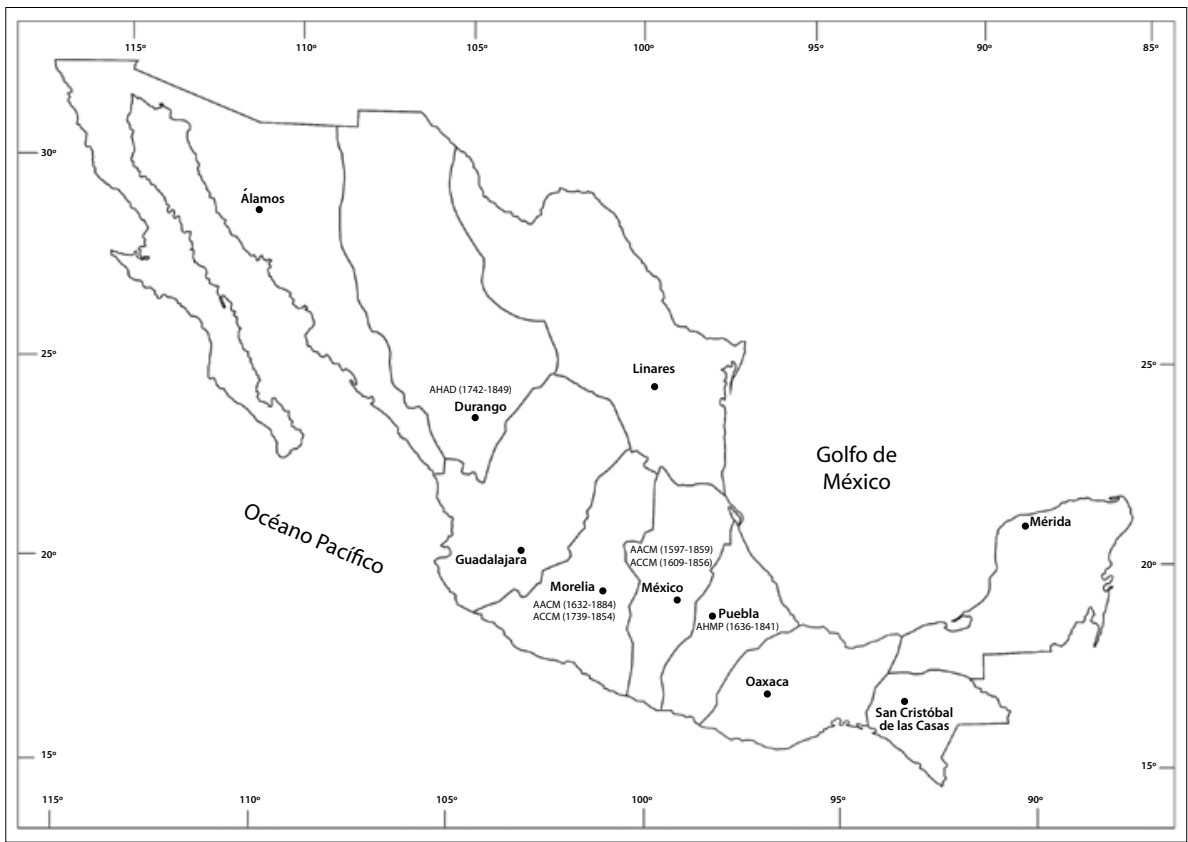

Figura 3. Mapa con la duración de las series climática propuestas a partir de un registro continuo de ceremonias de rogativa en México, Morelia, Puebla y Durango. 
5. Archivo Histórico Municipal de Puebla (AHMP): esta es la única serie climática que comienza con un ceremonial pro serenitatem el 19 de agosto de 1636 (AHMP, vol. 18, doct. 172, 193f-193v) y termina con uno pro pluvia el 17 de julio de 1841 (AHMP, Libro 108; 1841).

\section{La información climática del siglo XVI}

Con respecto al siglo XVI, ya se ha aducido que es imposible definir comportamiento climático alguno, limitándose las referencias a datos aislados encontrados en las actas de cabildo de México, Morelia y Puebla, siendo el más antiguo tocante a una cuestión climática el encontrado en el antiguo ayuntamiento de México y fechado el 5 de diciembre de 1530 (AACM, vol. 630a; 1529-1530): “... y se espera necesidad de trigo por lo mucho que se ha helado...”. A partir de este extracto se puede inferir que el invierno de 1530 a 1531 fue bastante severo, pero para la primavera la situación de abastecimiento de trigo había mejorado (AACM, vol. 630a; 1529-1530, 15-V-1531); en general se tiene que entre fines de la década de 1520 y principios de la década de 1540 el precio del trigo fue barato, teniéndose como única alteración grave el invierno arriba mencionado.

Aunque no conocemos a detalle las variaciones meteorológicas extremas de mediados de la década de 1540, parecen ser el inicio de una década terrible en términos climáticos y epidemiológicos. Tan temprano como 1541 y 1542 se tiene noticia de falta de trigo (AACM, vol. 632a; 1532-1543, 22-II-1541, 27-X-1541 y 20-X-1542). Para el invierno de 1543 ya se precisa que la mayor parte de las sementeras de trigo se habían helado en los alrededores de la capital (AACM, vol. 634a; 1543-1550, 3-XII-1543), lo que significó carestía de granos hasta el verano del subsecuente año (1544), tal y como reportan documentos fechados el 15 de mayo, el 21 de junio y el 10 de julio. Manifestándose la escasez de granos de nuevo tan sólo al entrar el siguiente invierno (AACM, vol. 634a; 1543-1550, 5-I1545, 19-I-1545 y 26-I-1545). Tal situación perduró hasta la primavera de 1545, complicándose la situación al final de esta, cuando una terrible epidemia asoló a la cuenca de México. Tuvo lugar entonces la primera procesión que se acota en las actas de cabildo del ayuntamiento capitalino (AACM, vol. 634a; 1543-1550, 15-VI-1545); tan funestas fueron las consecuencias de este capítulo epidémico que el número de tierras sin cultivar se vio incrementado. Las actas de cabildo de la catedral de México también dieron cuenta de lo cruento de esta epidemia (ACCM, Libro 1; 1536-1559, 24-IV-1545), cuyas secuelas, en cuanto al desabasto de alimentos, perduraron hasta la primavera de 1547 (AACM, vol. 634a; 1543- 
1550, 23-V-1547), tal y como manifiesta este extracto, en el que se ordenaba que se cumplieran los tributos de acuerdo con las tasaciones establecidas.

El quinquenio 1550-1555 ha sido ampliamente reconocido en la literatura paleoclimática, desde hace tiempo, por sus extremos mínimos en precipitación, desde el centro-sur de México hasta el oeste de los Estados Unidos. Para Acuńa y colegas (2002) es posiblemente el evento de sequía más acusado del milenio. La información proveniente de las actas de cabildo del ayuntamiento de la Ciudad de México nos dice que para el 6 de marzo de 1550 (AACM, 634a; 1543-1550) se expandía el radio de sementeras de maíz y trigo que debían abastecer a la capital a 15 leguas (unos 75 kilómetros), teniéndose que durante el invierno de 1552 se manifestó escasez de trigo (AACM, vol. 635a; 1550-1561, 29-II-1552) y para el verano de 1553 escasez general de granos (1-VIII-1553). Insuficiencia que también fue asentada en Puebla, pidiéndose que se manifestase qué cantidad de grano había en Atlixco (AHMP, vol. 6; doct. 238, 226f-233v, 13-II-1553).

El ciclo de extrema escasez en precipitación y de granos se cerró a fines del verano y principios del otoño de 1555 (AACM, vol. 635a; 1550-1561, 14-X-1555), cuando la capital novohispana quedó anegada por lluvias que fueron calificadas como extraordinarias y tardías. Sin embargo, lo fragoso de la variabilidad climática continuó manifestándose con un invierno severo, que heló los trigales (AACM, vol. 635a; 1550-1561, 23-XII-1555 y 24-II-1556) y habiéndose tenido de nuevo un fin de verano muy lluvioso que inundó nuevamente a la capital (AACM, vol. 635a; 1550-1561, 7-IX-1556). A esto siguieron un invierno y una primavera muy secos, lo que dio lugar al registro de la rogativa pro pluvia más antiguo que se tiene, asentada el 31 de mayo de 1557 (AACM, vol. 635a). Aunque no se tiene la certeza que haya sido el primer ceremonial pro pluvia que se hubiese conducido, la explicación que en el extracto se da sobre la forma en que la procesión debía llevarse a cabo, y la exaltación a la necesaria participación de todos los actores económicos, políticos, sociales y religiosos, permiten pensar que posiblemente sí lo fue.

Después de estas últimas referencias, la Ciudad de México parece no tener mayores vicisitudes ambientales hasta 1573; por su parte, Puebla no ha manifestado carencia de lluvia, pero si excesos hídricos y amenazas a la vida humana por tempestades y rayos. Tan relevantes fueron las mortificaciones a este respecto, que el 9 de mayo de 1561 se otorgó la siguiente merced (AHMP, vol. 8; doct. 179, 136v-139f): "Merced de seis solares al canónigo Andrés Sánchez de Soto en un montecillo cerca del camino que va a Santiago Cuautinchan para hacer una casa y una capilla en la que se digan oraciones contra las tempestades". Dos años des- 
pués (1563) se reportó falta de trigo en Puebla y Atlixco, sin que se definiera qué la motivó (AHMP, vol. 9; doct. 15, 9f-10v, 9-VII-1563).

Un invierno posiblemente muy severo hizo que se solicitase durante la primavera de 1573, el trigo y el maíz de una comarca, relativamente lejana a la capital, como era Atlixco (AACM, vol. 637a; 1571-1584, 10-IV-1573), la cual comúnmente sólo abastecía a Puebla, reportándose problemas de abasto de granos hasta la primavera de 1577 (AACM, vol. 637a; 1571-1584, 26-IV-1577), y se llegó diez días después a la necesidad de recurrir de nuevo al trigo de Atlixco (6-V-1577). A lo largo de la década de 1580, el invierno de 1583 parece haber sido bastante crudo, y de ello dan cuenta tanto el cabildo del ayuntamiento (AACM, vol. 637a; 1571-1584, 8-II-1583) como el cabildo de la catedral (ACCM, Libro 3; 1576-1588, 22-III-1583), así como el otońo de 1586 en Puebla (AHMP, vol. 12; doct. 77, 75f77f, 24-X-1586).

Durante la segunda mitad del siglo XVI, después de la década de 1550, la de 1590 parece ser en el centro-sur de México la más anómala: en 1593 la escasez de granos duró de la primavera de ese ańo hasta el invierno de 1594 (AACM, vol. 640a; 1590-1593, 21-V-1593 y 14-VI-1593; AHMP, vol. 12; doct. 305, 261f-263f, 14-XII-1593 y AACM, vol. 641a; 1594-1597, 14-I-1594). Asimismo, en la ciudad de Puebla aconteció una fuerte epidemia entre fines de 1595 y principios de 1596 (AHMP, vol. 12; doct. 359, 309f-311v - doct. 400, 335f-337f, 15-XII-1595 y doct. 418, 349f-351f, 10-V-1596). El extremadamente seco verano de 1597 dio lugar al registro de ceremonias de rogativa con el que se inicia la serie climática para la Ciudad de México, por lo que se trata en el siguiente apartado.

\section{Series climáticas}

La trayectoria climática es un continuo que es difícil desglosar en términos cronológicos; sin embargo, con la idea de hacer más asequibles los datos climáticos obtenidos a través de la consulta de las actas de cabildo civil y eclesiástico en el centro-sur de México, se propone separar las series climáticas y la crónica de los eventos climáticos en tres temporalidades: siglo XVII, siglo XVIII y siglo XIX. Temporalidades que se definen en la medida de lo posible de acuerdo con la trayectoria climática; por lo tanto, el siglo XVII se prolonga en esta síntesis hasta 1711, año que parece cerrar sobre el Eje Neovolcánico las calamidades meteorológicas ocurridas como consecuencia del mínimo Maunder: las consecuencias de los dos mínimos en manchas solares (Maunder circa 1645-1715 y Dalton circa 17901820), durante la $\mathrm{PEH}$, han sido detalladas a partir de la información contenida 
en los registros de ceremoniales de rogativa en el número 84 de Investigaciones Geográficas (Garza, 2014).

\section{Siglo XVII}

El primer registro de rogativa, inicio de la serie climática para la Ciudad de México, fue resultado de un verano extremadamente seco: "Este día acordó la ciudad, que atento que la imagen de Nuestra Señora de los Remedios, de donde esta ciudad es el patrón, se traiga hoy, dicho día de su casa al monasterio de la Concepción y mañana día de nuestra señora se traiga en procesión a la Iglesia Mayor, para que sea intercesora que lleve de salud y buenos temporales a todo este reino..." (AACM, vol. 643a; 1597-1599, 16-VIII-1597). Las consecuencias de este episodio climático fueron tan severas que provocó escasez de granos hasta el otoño de 1598, situación que se complicó por fuertes heladas durante el invierno de 1598 (AACM, vol. 643a; 1597-1599, 5-I-1598, 5-II-1598, 12-II-1598, 3-IV-1598, 12-VI-1598 y 11-XII-1598). A estos eventos climáticos les antecedió una fuerte epidemia en las ciudades de México y Puebla (AHMP vol. 13; doct. 4, 5v-5v, 17I-1597): "Acuerdo para enviar una carta al virrey, para pedirle un informe de los resultados de la reunión de médicos, que trató las enfermedades que padece la Ciudad de México y de esta forma la Ciudad de Los Ángeles pueda saber la cura de esas enfermedades...”.

El infortunio de los habitantes de la Ciudad de México en los años de 1604 y 1605 fue causado por las fuertes precipitaciones que ocurrieron entonces (AACM, vol. 646a; 1605-1607, 27-X-1605 y ACCM, Libro 5; 1606-1616, 3-IX-1607). Situación que se agravó en 1607, tal y como manifiesta el siguiente extracto: "Este día se acordó que respecto de la aplicación en que se vio por las muchas aguas... Y asimismo, acordó la ciudad, que respecto de los milagros, que se han visto en necesidades y faltas de agua con la venida de Nuestra Señora de los Remedios a esta ciudad y las misericordias que nuestro señor por su intercesión ha hecho a este pueblo... en nombre de esta ciudad, vayan a comunicarlo con su excelencia... y en muchas calles no pueden salir los vecinos, sino es en canoas..." (AACM, vol. 647a; 1607-1610, 3-IX-1607). La gravedad de esta inundación hizo necesario que el ayuntamiento nombrara a San Gregorio Taumaturgo como "patrón y abogado de los daños que las aguas causan...” (AACM, vol. 647a; 1607-1610, 28-IX-1607). El exceso hídrico de este evento provocó "pocos y malos trigos" (ACCM, Libro 5; 1606-1616, 13-III-1608). 
No acababa de recuperarse la capital de las inundaciones cuando una primavera muy seca obligó a la realización de un ceremonial de rogativa de nivel III el 19 de junio de 1609; posiblemente no alcanzó un mayor nivel al haberse hecho coincidir las rogativas por las lluvias con las celebraciones del Corpus Christi (ACCM, Libro 5; 1606-1616, 19-VI-1609), que, como bien se sabe, era uno de los acontecimientos religiosos más relevante dentro del año litúrgico. Por un extracto, también resguardado en el libro 5 de las actas de cabildo de la catedral metropolitana, y firmado por el virrey Luis de Velasco hijo (14-VIII-1609), sabemos que para principios de agosto se encontraba lloviendo. Así, pasaron tres ańos antes de que la falta de lluvias hiciese necesario la realización de una rogativa; aparentemente de nuevo, una primavera muy seca hizo necesario un ceremonial de nivel III (ACCM, Libro 5; 1606-1616, 8-VI-1612).

El año de 1615 no dejó registro alguno de rogativa pro pluvia; sin embargo, para noviembre de ese año se reconoce la falta de "trigo, maíz y cebada", que pudieron ocasionar las heladas de ese otoño (AACM, vol. 650a; 1614-1617, 16-XI1615). Invierno severo, y primavera seca, que provocaron la necesidad de llevar a cabo un ceremonial pro pluvia de nivel V para el 7 de junio de 1616 (AACM, vol. 650a; 1614-1617). Coincidiendo los registros de los cabildos civil y religioso en lo terriblemente seco que resultaron la primavera y el verano de 1618, con el registro de una ceremonial pro pluvia de nivel III durante la primera estación (ACCM, Libro 6; 1617-1620, 24-IV-1618), y uno de nivel IV durante la segunda (AACM, vol.652a; 1618-1620, 27-VII-1618). 1620 fue un año cuyo verano fue testigo de inundaciones en la capital (AACM, vol. 652a; 1618-1620, 31-VIII-1620). Fuertes precipitaciones que también quedaron asentadas en las actas de cabildo del ayuntamiento de Puebla (AHMP vol. 16; doct. 7, 8v, 25-IX-1620). El comportamiento climático interestacional en diversas ocasiones quedó manifesto en extractos como el siguiente, al dar cuenta de que a pesar de haberse tenido inundaciones en agosto, para septiembre y octubre había dejado de llover, y siendo fines de mayo, la escasez de precipitación seguía siendo notoria, por lo que se hacía necesario, de acuerdo con el ayuntamiento de México, la realización de un ceremonial pro pluvia de nivel IV (AACM, vol. 653, 1621-1623, 28-V-1621):

... y decimos que habiendo sido las aguas del año pasado cortas y alzándose temprano las de este año tardan tanto, que a más de que la tierra está necesitadísima del rocío del cielo para que haya esperanza de coger este año algunos frutos, de ella los ganados, con que se verifican las haciendas están en tanto extremo flacos por falta de pasto que si Dios no socorre con brevedad con la abundancia de aguas que es natural en estos tiempos... 
Ceremonial que, seis días después (ACCM, Libro 7; 1620-1625, 4-VI-1621), fue propuesto por el cabildo eclesiástico para realizarse con la pompa de rogativas pro pluvia de nivel V. Aunque en Puebla no se encontró registro alguno de rogativa por falta de lluvias, si se halló un extracto que trata sobre la falta de maíz (AHMP vol. 16; doct. 64, 69v, 24-IX-1621). Pasarían dos años antes que la falta de agua hiciese necesario una rogativa pro pluvia de nivel IV (AACM, vol. 655a; 1621-1625, 19-V-1623). Ese año y el siguiente al parecer se caracterizaron por primaveras muy secas, ya que para el 12 de junio de 1624 (AACM, vol.655a; 16211625) fue necesaria otra rogativa pro pluvia de nivel IV. Dos años más tarde (1626) se enfrentó de nuevo una primavera muy seca, que hizo necesario realizar ceremoniales pro pluvia de nivel III, tan pronto en el ańo como el 8 de mayo (ACCM, Libro 8; 1626-1632).

El resto de la década de 1620 y principios de la década de 1630, la Ciudad de México virreinal sufrió las peores inundaciones de su historia. La inestabilidad climática del funesto año de 1627 se manifestó primeramente con fuertes heladas a fines de la primavera, más acusadas en los alrededores de Toluca (AACM, vol. 659a; 1626-1628, 11-VI-1627). Unos días después de tan inusual evento, comenzaron fuertes precipitaciones que derivaron en la necesidad de organizar una rogativa pro serenitatem de nivel IV, solicitando el favor de san Gregorio Taumaturgo (25-VI-1627). La ruina de la ciudad y la continuidad de las precipitaciones quedaron asentadas en un documento fechado el 29 de octubre (AACM, vol. 659a; 1626-1628). El desabasto de granos, como consecuencia de los eventos climáticos mencionados en este párrafo, fue referido el 31 de enero de 1628, al no haberse “... cogido maíz en la provincia de Toluca y Chalco...” (AACM, vol. 659a; 1626-1628). Las fuertes precipitaciones de 1627 también fueron asentadas en los registros del ayuntamiento de Puebla (AHMP, vol. 17; doct. 17, 75v, 1-IX-1627 y doct. 100, 103f, 28-IV-1628).

Las reseńas sobre el anegamiento de la Ciudad de México durante casi cinco años, entre 1627 y 1632, son bastante conocidas. Aunque no se pone en tela de juicio la abundancia extrema de precipitaciones, debe recordarse que tan difícil situación pudo ser, a su vez, consecuencia de las profunda transformaciones ambientales que la cuenca de México había sufrido en términos hidrográficos, edáficos y de cubierta vegetal a raíz de la implementación de los medios y los modos de producción europeos (Garza, 2000). A continuación se refieren cinco extractos sobre la situación vivida por aquel entonces:

... y respecto de ser tan trabajoso en el que México se halla con la rigurosa inundación que padece... y pena con que esta ciudad con la mucho agua que la 
ocurre... los pobres de sus barrios que inhabilitados de poder salir de ellos por hallarse anegados, perecen muchos por falta de sustento... (AACM, vol. 660a; 1628-1630, 22-IX-1629).

... que se escriba a su majestad y su real consejo de Indias, carta para cuatro duplicados, que contenga como se ha anegado toda esta ciudad totalmente y que se han caído muchas casas y las demás prometen ruina y que los vecinos, la mayor parte se han ido...y que ha cesado el comercio... (AACM, vol. 660a; 1628-1630, 31-X-1629).

... para conferir los remedios de la inundación que esta ciudad padece... respecto de que va menguando ya el agua y conviene esperar a ver el efecto en estos quince días, sin usar de otros instrumentos y que ahora sólo se trate de facilitar el comercio... con toda brevedad haga se pongan puentes de madera altas para el comercio... (AACM, vol. 660a; 1628-1630, 5-XI-1629).

... propone a la ciudad que será bien se prevenga para el rigor de las aguas, de tener los abastecimientos precisos, prevenidos para que no falten... con ocasión de haberse caído en los barrios, casas de adobe y piedra, los dueńos pareciéndoles que el daño ha de ser mayor... (AACM, vol. 660a; 1628-1630, 15-IV-1630).

... se ha conocido el poco fruto que resulta en los artificios puestos en algunas calles para vaciarlas... y las aguas continúan con anticipación de los pasados... (AACM, vol. 660a; 1628-1630, 12-VIII-1630)

Lo dramático de la situación, provocó la necesidad de contar con una nueva advocación ante las inundaciones, responsabilidad que fue asignada a la virgen de Guadalupe con rogativas de nivel V pro serenitatem, mismas que fueron conducidas a pesar de la inundación en la catedral (ACCM, Libro 8; 1626-1632, 4-X-1629). Asimismo, Puebla sigue reportando daños en sus vías de comunicación y acueductos (AHMP vol. 17; doct. 192, 193v, 15-I-1630 y doct. 193, 194v, 18-I-1630).

Para cuando la inundación ha finalmente remitido en la capital novohispana, en Morelia se manifiesta un fin de verano bastante seco, mismo que dio a lugar a una rogativa pro pluvia de nivel III el 17 de septiembre de 1632 (ACMM, Libro III; 1626-1634). Situación que se repitió al año siguiente (1633), de nuevo con un fin de verano muy seco, generando la necesidad de conducir un ceremonial de rogativa pro pluvia de nivel IV, el 30 de agosto (ACMM, Libro III; 1626-1634). 
Los años de 1634 y 1635 no parecen ser muy calamitosos en términos meteorológicos, pero tanto en la capital como en Puebla existen registros sobre epidemias (AHMP vol. 18; doct. 57, 56v-57f, 14-VIII-1634 y ACCM, Libro 9; 1633-1639, 16I-1635), y el 1 de junio de 1635 se ordenó en la catedral de Morelia la realización de una rogativa pro pluvia de nivel I (ACMM, Libro IV; 1635-1638, 1-VI-1635).

La abundancia de aguas en Puebla fue de nuevo motivo de ceremoniales de rogativa pro serenitatem el 19 de agosto de 1636, en tanto que los rayos y tempestades, ya habían ocasionado el deceso de diecinueve personas (AHMP, vol. 18; doct. 172, 193f-193v). En contraposición, en Morelia se asombraban de haber podido segar trigo por lo soleado y relativamente escasas que habían sido las lluvias aquel verano, aduciendo que, por lo general, se veían en la necesidad de segar los trigos en mayo (AHMM, Libro 2; 1616-1739, 16-VIII-1636). Dos años después se hizo patente la necesidad de una rogativa pro pluvia de nivel $V$ en Morelia por causa de un verano muy seco (ACMM, Libro V; 1638-1640, 4-IX-1638).

La necesidad de lluvia a principios de junio de 1639 y el que comenzara a llover a fin de ese mes queda claramente explicado en sendos documentos, generados por los cabildos civil y eclesiástico de México (AACM, vol. 661a; 1635-1639, 9-VI-1639 y 28-VI-1639, y ACCM, Libro 9; 1633-1639, 11-VI-1639). Este último extracto también da cuenta de los agravios y enfrentamientos epistolares entre los cabildos civil y eclesiástico, diplomacia que alcanzó situaciones límite después de las reformas borbónicas, por no hablar de los liberales y sus relaciones con la Iglesia después de la independencia:

Habiéndose leído un papel del cabildo y regimiento de esta ciudad, en que parece dar forma en la traída de la santa imagen de María de los Remedios a esta Santa Iglesia por la necesidad que había de que lloviese, por cuya falta estaba la ciudad con muchas y graves enfermedades. Se resolvió que no se admitiese el papel, ni se ejecutase cosa alguna de las que contenía, por no venir en debida forma y por quererse la ciudad arrogarse a sí, lo que no le toca, que es dar modo a las procesiones, señalando días, calles y lugares por donde pasase la santa imagen; antes se llevase al señor Virrey, significándole el sentimiento con que el Cabildo Eclesiástico estaba de que los seculares quisiesen introducirse en lo que es tan propio del cabildo eclesiástico...

Pasaron dos años hasta que en 1641, tanto en México como en Morelia, se manifestó la necesidad de lluvia; en la primera ciudad se condujo un ceremonial de rogativa pro pluvia de nivel $\mathrm{V}$, mientras que en la segunda se hicieron ceremonias de nivel IV (AACM, vol. 664a; 1640-1643, 10-VI-1641; ACCM, Libro 10; 
1640-1650, 11-VI-1641 y ACMM, Libro VI; 1640-1649, 14-VI-1641). En abril de 1642 ya se resentía lo anómalo del año anterior y el precio del maíz era elevado (AACM, vol. 664a; 1640-1643, 28-IV-1642); a la par, el tiempo de esa primavera no auguraba un buen año, y para el 9 de mayo ya se estaba solicitando una rogativa de nivel II por "la salud pública". Extractos fechados en 15 de mayo, 19 de mayo y 25 de junio, dan cuenta de un mayo y un junio extremadamente secos, habiéndose ordenado una rogativa pro pluvia de nivel $\mathrm{V}$ en la penúltima fecha, ceremoniales que también dejaron registro en el archivo de la catedral de México (ACCM, Libro 10; 1640-1650, 23-V-1642). Otra rogativa pro pluvia de nivel V se hizo necesaria en agosto, y por lo que argumenta esta documentación, al menos todo el mes de agosto fue muy seco (AACM, vol. 664a; 1640-1643, 11-VIII-1642 y 29-VIII-1642). Extractos en los que también se hace patente la presencia de epidemias ante tan anómalos tiempos (ACCM, Libro 10; 1640-1650, 29-VIII-1642), y para fin de año la escasez en la alhóndiga de la capital era evidente (AACM, vol. 664a; 1640-1643, 23-XII-1642). Aunque no existen registros de ceremonia de rogativa en Puebla durante estos años, para noviembre de 1643 se reconoce carestía de trigo (AHMP, vol. 20; doct. 48, 83f-85v, 11-IX-1643). Los malos tiempos continuaron hasta la primavera de 1644, ya que para el 20 de mayo se solicitaba la realización de dos rogativas pro pluvia de nivel III, una en el santuario de Los Remedios y otra en la catedral. En este extracto también se hace evidente la presencia de enfermedades, ante lo extremo del tiempo (ACCM, Libro 10; 1640-1650).

Si el inicio de la década de 1640 fue bastante difícil para las ciudades de México, Morelia y Puebla, el resto de la misma, transcurrió tranquilamente en cuanto a dificultades meteorológicas se refiere. Siendo que hasta el año de 1652, se reconoce como un año extremadamente húmedo, tanto en Morelia, como en Puebla. Por la información hallada se sabe que en Morelia tuvieron un principio de temporada de lluvias bastante violento (ACMM, Libro VII; 1650-1656, 12-VI1652), quedando asentado en ese mismo libro, que para septiembre ya les preocupaba el que las semillas se pudriesen por tanta humedad (24-IX-1652). En Puebla ese año, las vías de comunicación, de nuevo resintieron el embate de las aguas (AHMP, vol. 23; doct. 112, 230v, 5-X-1652). Por su parte, en Morelia el verano de 1654 fue tan seco que para el 7 de agosto se habían organizado los ceremoniales de una rogativa pro pluvia de nivel IV (ACMM, Libro VII; 1650-1656). Esta misma ciudad realizó una rogativa de nivel III contra la peste la siguiente primavera (ACMM, Libro VII; 1650-1656, 9-IV-1655).

La Ciudad de México no cuenta con pruebas de anomalías ambientales graves entre 1644 y 1657. Este último ańo la capital se encontraba para octubre en peligro de inundación, por lo que se ordenaron rogativas pro serenitatem de 
nivel II (ACCM, Libro 13; 1656-1660, 16-X-1657). El resto de la década de 1650 transcurrió sin mayores sobresaltos, hasta que las ciudades de México y Morelia se vieron amenazadas por la peste en la primavera y otońo de 1659 , respectivamente (ACCM, Libro 13; 1656-1660, 31-V-1659 y ACMM, Libro VIII; 1656-1664, 17-XI-1659).

El inicio de la década de 1660 fue bastante inestable en términos climáticos: para mayo de 1661 la falta de lluvias y las enfermedades eran patentes en la capital, por lo que se ordenó la realización de una rogativa de nivel II con la finalidad de atajar ambas amenazas; sin embargo, la falta de precipitación continuó y para mediados de junio se hizo necesario solicitar la realización de una rogativa pro pluvia de nivel V (ACCM, Libro 14; 1661-1662, 10-V-1661 y 10-VI-1661). Un invierno y primavera secos debieron caracterizar el inicio de 1662, pues durante mayo y junio de ese ańo se condujeron dos rogativas pro pluvia de nivel II (ACCM, Libro 14; 1661-1662, 9-V-1662 y 6-VI-1662). De nuevo, el siguiente año (1663) se manifestó seco, y para el 20 de junio se había hecho necesario la gestión de un ceremonial de rogativa pro pluvia de nivel V (ACCM, Libro 15; 1663). Esta falta de lluvia también obligó en Puebla a solicitar una rogativa pro pluvia de nivel IV el 9 de mayo de 1663 (AHMP, vol. 25; doct. 209, 432f-433v). Dos ańos después (1665), graves contagios asolaron también a esta última ciudad (AHMP, vol. 26, doct. 58, 125v-126v, 16-III-1665).

La década de 1660 se caracterizó por un inicio y un final un tanto difíciles por causas climáticas. En Morelia, para fines de abril se advertía el peligro de heladas, por lo que se llevó a cabo una rogativa de nivel III (ACMM, Libro IX; 1664-1669, 26-IV-1667), y un mes más tarde, en Puebla, se denunciaba la falta de lluvias, situación que se buscó remediar por medio de una rogativa pro pluvia de nivel IV (AHMP, vol. 27; doct. 23, 54f-54v, 1-VI-1667). Un año después, por las mismas fechas, Puebla se vio de nuevo amenazada por la falta de lluvias, habiendo sido necesario recurrir a una rogativa pro pluvia de nivel IV (AHMP, vol. 27, doct. 86, 187f, 11-VI-1668). Este ciclo de inestabilidad se cerró en 1669 con un invierno y una primavera secos, lo que obligó el 21 de mayo a la conducción de un ceremonial de rogativa pro pluvia de nivel III en la capital del virreinato (ACCM, Libro 17; 1667-1669).

Entre 1669 y 1676 la única vicisitud de orden climático, al parecer, fueron fuertes tormentas en Morelia a fines de julio de 1670 (ACMM, Libro X; 16691679, 1-VIII-1670), lo que motivó un ceremonial pro serenitatem de nivel IV. La primavera de 1676 se manifestó lo suficientemente seca en Puebla como para que su ayuntamiento se viera en la necesidad de solicitar una rogativa pro pluvia de nivel IV el 12 de junio (AHMP, vol. 28, doct. 214, 527v-528f). A pesar de una 
primavera seca, el verano fue bastante lluvioso, tal y como manifiesta un extracto de este mismo ayuntamiento (AHMP, vol. 29, doct. 1, 2f-3v, 7-VIII-1676). Una primavera muy húmeda azotó a Puebla en 1677, precipitaciones extremas que dañaron calles y conventos en dicha ciudad (AHMP, vol. 29; doct. 32, 80v-82v, $11-\mathrm{V}-1677$ y doct. 40, 107v-110f, 19 de julio). En contraposición, el invierno y primavera siguientes fueron muy secos, lo que obligó tan pronto en el año, como el 16 de mayo, a realizar en Puebla una rogativa pro pluvia de nivel IV (AHMP, vol. 29; doct. 82, 256f-266f).

Así, pasaron cinco años sin alarmas provocadas por la variabilidad climática, hasta que la primavera de 1682 volvió a dar en Puebla signos de tiempos secos. Circunstancia que hizo necesaria la ejecución de una rogativa pro pluvia de nivel IV (AHMP, vol. 30; doct. 101, 280v-284v, 13-V-1682). Repitiéndose una situación prácticamente idéntica al año siguiente (AHMP, vol. 30; doct. 129, 409v-410f, 5-V-1683), respondiendo la ciudad de Puebla con una rogativa del mismo nivel. A fines de julio en Morelia, se llevó a cabo un ceremonial de nivel III ante la falta de lluvias (ACMM, Libro XI; 1679-1688, 27-VII-1683). 1684 fue un año calamitoso para Morelia: para el 9 de junio se reportaba que el "tiempo era riguroso de soles", y para fines de agosto se estaba solicitando una rogativa pro pluvia de nivel IV, manifestándose asimismo que la falta de lluvias era general en todo el obispado (ACMM, Libro XI; 1679-1688, 9-VI-1684 y 25-VIII-1684). El año siguiente (1685) manifestó de nuevo una primavera seca, lo que hizo necesario organizar un ceremonial de rogativa pro pluvia de nivel IV el 16 de junio (ACMM, Libro XI; 1679-1688), acotándose en ese mismo extracto que las enfermedades ya eran generalizadas y la mortandad del ganado elevada. Para 1686, fue Puebla la ciudad que denunció de manera muy temprana la falta de lluvia y la presencia de enfermedades (AHMP, vol. 31; doct. 79, 278f-278v, 2-V-1686), haciéndose necesaria una nueva rogativa pro pluvia, esta vez de nivel III, a principios de septiembre (doct. 85, 285f-291f, 4-IX-1686). Después de cinco años de falta de lluvias, ya en Puebla, ya en Morelia, no existe registro de otro evento seco, hasta la primavera de 1689 en Morelia, donde se solicitaron rogativas pro pluvia y contra las enfermedades de nivel III, el 18 de mayo de 1689 (ACMM, Libro XII; 1688-1697).

El evento agroclimatológico conocido como el año de chahuixtle (1691) ha sido ampliamente referido en las crónicas sobre la capital del virreinato, ya que su consecuencia política más grave fue el incendio del palacio virreinal el 8 de junio de 1692 (ACMM, Libro XII; 1688-1697, 16-VI-1692). Esta rebelión fue consecuencia de la pérdida de alimentos generada por excesos hídricos y nublados constantes. En Morelia, los acontecimientos de la capital y el panorama meteorológico que enfrentaban, hizo necesario refrendar el novenario anual que se realizaba a 
San José contra las tempestades y rayos, así como realizar rogativas por la pacificación de la capital, esto de acuerdo con el extracto arriba citado. La carestía de granos todavía se encontraba vigente a principios del año siguiente (AACM, vol. 371-A; 1692-1693, 16-III-1693), habiéndose tenido que traer maíz de sitios tan lejanos como Querétaro, Celaya y León. Como en tantas otras ocasiones, la alteración profunda de los patrones climáticos usuales dieron lugar a la manifestación de epidemias (ACCM, Libro 23; 1691-1694, 2-X-1692). Por su parte, la ciudad de Puebla da constancia de una rogativa pro pluvia de nivel V el 17 de mayo de 1692 (AHMP, vol. 33; doct. 21, 65v). Tal premura y nivel de ceremonial no es de extrañar, si se toma en cuenta que la alhóndiga de esta ciudad no recibía un solo grano de trigo desde agosto de 1691 (doct. 25, 70f-70v, 14-VI-1692). Por último, cabe mencionarse que Puebla no sufrió los rigores del hambre gracias a la generosidad de su obispo, quien proveyó de su hacienda maíz y trigo para abastecer la alhóndiga de esta ciudad (AHMP, vol. 33; doct. 42, 128f, 30-X-1692).

La terrible situación vivida durante 1691 y 1692 hizo que desde principios de abril de 1693 se solicitara en la capital la realización de rogativas por los buenos temporales de nivel IV; por lo visto, el invierno y el inicio de la primavera fueron secos como para temer alguna catástrofe a lo largo del año (ACCM, Libro 23; 1691-1694, 3-IV-1693 y 8-IV-1693). Por las mismas fechas, Puebla se encontraba asolada por la epidemia, y su ayuntamiento solicitaba la realización de una rogativa de nivel IV para atajar esta urgencia (AHMP, vol. 33, doct. 64, 209f-209v, 6-IV-1693). Desafortunadamente, el resto de la década de 1690 continuó siendo bastante severa; la primavera de 1694 se manifestaba seca hasta junio, por lo que se hizo necesario gestionar una rogativa pro pluvia de nivel V (ACCM, Libro 23; 1691-1694, 8-VI-1694), aclarándose que el ceremonial sería conducido con la misma pompa con que se hacían las rogativas, cuando la virgen de Los Remedios era traída de su santuario, en tanto que por las calamidades de aquellos años, dicha imagen llevaba más de dos años en la catedral. Los desesperados habitantes de la capital pudieron respirar en paz más tarde ese año, ya que el 31 de octubre se ordenaba un Te Deum en agradecimiento por los buenos temporales habidos ese verano y principios de otoño (ACCM, Libro 23; 1691-1694). Sin embargo, documentos fechados en Puebla al ańo siguiente dan a entender que los granos aun escaseaban e, incluso, quedaba prohibido alimentar cerdos con mazorcas (AHMP, vol. 33; doct. 160, 608f, 6-VI-1695; doct. 169, 628v-629v, 28-IX-1695; doct. 170, $631 \mathrm{v}-632 \mathrm{v}, 10-\mathrm{VII}-1695$ y doct. 178, 663v-664f, 31-XII-1695).

Los sobresaltos continuaban, y un invierno y primavera secos hicieron que en fecha tan temprana como el 7 de mayo se impulsara la realización de una rogativa pro pluvia de nivel III, y al no obtenerse resultados se organizaron otros 
ceremoniales. La gravedad de los tiempos y la espera de lluvias durante un agónico mes de mayo quedan reflejados en los siguientes extractos. Habiéndo sido tan desesperada la situación, y al no haber rendido frutos la rogativa de nivel V, se echó mano a fin de mes de otras advocaciones (ACCM, Libro 24; 1695-1698, $11-\mathrm{V}-1696,15-\mathrm{V}-1696,25-\mathrm{V}-1696$ y $27-\mathrm{V}-1696)$ :

... la ciudad enviaba dos regidores comisarios a dar presente de haberse determinado por el real acuerdo que el lunes catorce por la tarde se ha de traer en procesión a esta Santa Iglesia la santísima imagen de Nuestra Señora de los Remedios por la falta de aguas... En orden a que la falta de lluvias y por las demás necesidades públicas, sería bien se hiciese una procesión y novenario en esta dicha Santa Iglesia, trayendo a ella a dicha santa imagen... trayéndola en la forma en que se trae a Nuestra Señora de los Remedios... trayéndose por la mañana al convento de religiosas de Santa Isabel y a la tarde a dicha Santa Iglesia, el novenario a Santísimo Sacramento por falta de aguas que se acabará el martes y a la tarde podrá traerse dicha santa imagen... (rogativa pro pluvia de nivel V)...

El día veinticinco de mayo a las cinco de la tarde salió de esta Santa Iglesia Metropolitana, la santísima imagen de Nuestra Señora de la Redonda con la misma asistencia de cofradías, religiones, cabildo eclesiástico y clero, ciudad, tribunales... habiendo sido todo el novenario con grandes calores y sin agua; amaneció este día nublado y a las tres de la tarde llovió moderadamente y quedó la tarde nublada y fresca... desde este día prosiguió lloviendo, aunque poco, en México, mucho en los contornos de los montes y alrededores y se prosiguió en Santa Clara otro novenario (rogativa pro pluvia de nivel III)...

Habiendo el sábado diecinueve del corriente, mes de mayo, llevándose del Real Convento de Santo Domingo y capilla de Los Negros, al convento de religiosos de San Fernando; en procesión de mortificación por la falta de aguas, el Santo Crucifijo de la Expiración y hechósele su novenario, volviéndola el martes por la tarde de veintinueve del corriente por llover recientemente (rogativa pro pluvia de nivel IV)...

Por esas mismas fechas, en Morelia se clamó por la realización de una rogativa pro pluvia de nivel V (ACMM, Libro XII; 1688-1697, 11-V-1696). Para fortuna de esta ciudad se reportaba seis días después que la cosecha de trigos se había logrado (ACMM, Libro XII; 1688-1697, 17-V-1695), y se solicitaba una misa cantada en señal de agradecimiento. Por su parte la ciudad de Puebla sólo reportó, entre 
1696 y 1699, afectaciones a sus infraestructuras ante la violencia de las lluvias (AHMP, vol. 34; 1696-1701, doct. 19, 77f, 12-VII-1696; doct. 53, 239v-241f, 17X-1697; doct. 75, 324f-348f, 12-V-1698 y doct. 107, 455f-455v, 1-VIII-1699). El temor a un nuevo episodio de perdida de granos por causa del chahuixtle hizo que a principios de 1699, se hicieran rogativas en la capital para impetrar por el favor del cielo, en el logro de buenas cosechas. Situación de la que salió bien librada esta ciudad, ya que para el 13 de mayo se realizaban misas y procesiones para dar las gracias por tan venturosas nuevas (ACCM, Libro 25; 1698-1701 y AACM, vol. 372-A; 1698-1705, 27-IV-1699).

La inclusión de los primeros siete años del siglo XVIII, en el apartado dedicado al siglo XVII, obedece a que estos años muestran continuidad con respecto a los eventos de la década anterior, caracterizada por su fuerte irregularidad climática: una primavera extremadamente seca motivó la realización de una rogativa pro pluvia de nivel V el 3 de junio de 1701 (AACM, vol. 372-A; 1698-1705), habiendo sido necesario un ceremonial igual un año después (2-VI-1702). Hubo un respiro durante 1703 , pero el invierno y primavera de 1704 resultaban tan secos que para el 18 de abril se ordenaba la conducción de un ceremonial pro pluvia de nivel IV (AACM, vol. 372-A; 1698-1705). De nuevo, prácticamente un año después, el 8 de mayo de 1705, se registra de nuevo una rogativa pro pluvia de nivel IV (AACM, vol.372-A; 1698-1705). Para la primera década del siglo XVIII Morelia únicamente manifestó la presencia de epidemias el 7 de mayo de 1700 (ACMM, Libro XIII; 1697-1703). Por su parte, la ciudad de Puebla daba a conocer por aquellos años carestía de ganados provocada por la "calamidad de los tiempos y malos temporales que se han padecido" (AHMP, vol. 35; 1702-1707, f.456v, 16-IX-1706) y precipitaciones extremas en agosto de 1707 (AHMP, vol. 35, f.528v, 13-VIII-1707).

\section{Siglo XVIII}

El primer evento de dimensiones catastróficas, dentro del marco temporal que se ha definido como siglo XVIII en este resumen, ocurrió en la primavera de 1711. Capítulo de extrema sequedad y calores, así como de epidemias, que por su severidad fue denunciado en la Ciudad de México desde abril. Conduciéndose entonces una rogativa de nivel IV en la que se pedía por el fin de las enfermedades, ceremonial organizado por el cabildo de la catedral, bajo el amparo de Santa María de la Redonda (ACCM, Libro 27; 1710-1713, 14-IV-1711). Sin embargo, las circunstancias no mejoraron y para el 22 de mayo, el ayuntamiento exhortó a la 
realización de una rogativa pro pluvia de nivel IV, bajo el patrocinio de la virgen de Los Remedios (AACM, vol. 665a; 1706-1713). Este evento también dejo huella en Morelia, siendo que el 21 de mayo se ordenó la conducción de rogativas pro pluvia de nivel V (ACMM, Libro XIV, 1703-1711). Dos años después (1713) se llevaron a cabo en la capital del virreinato ceremoniales de rogativa pro pluvia de nivel IV el 26 de mayo y de nivel V el 16 de junio (AACM, vol. 665a; 1706-1713).

El resto de la década de 1710, al parecer, fue relativamente benevolente, hasta los años de 1717, 1718 y 1719. En el primer año fue necesaria la realización de una rogativa de nivel IV en México a principios de junio (ACCM, Libro 29; 1717-1721, 8-VI-1717), mientras que el segundo manifestó enfermedades y carestía de trigo tanto en la capital como en Puebla (AACM, vol. 667a; 1714-1719, 20-VII-1718 y AHMP, vol. 39; 1717-1719, 12-VII-1718). En el tercer año la falta de lluvias y extremos calores fue tan fuerte que para el 5 de junio de 1719 se verificó una rogativa pro pluvia de nivel V (AACM, vol. 667a; 1714-1719). Por su parte, los trigos de invierno en la jurisdicción de Morelia se encontraban en peligro de perderse a principios de marzo de 1719, por lo que se solicitó la realización de una rogativa de nivel II (ACMM, Libro XVII; 1718-1725, 1-III-1719).

La década de 1720 no comenzó de mejor talante en cuanto a lo climático, y para junio se hizo necesario conducir rogativas pro pluvia de nivel $V$ en México (AACM, vol. 668a; 1720-1722, 10-VI-1720 y ACCM, Libro 29; 1717-1721, 18-VI1720). En el primer extracto de nuevo se hace referencia a que la virgen de Los Remedios ya se encontraba en la catedral, por lo que el ceremonial debía subsanar la imposibilidad de incluir la procesión desde su santuario con otras pompas, con tal de alcanzar rogativas de nivel V. Este año también afectó severamente a Morelia, ciudad en la que se celebró un ceremonial pro pluvia de nivel V el 20 de agosto (ACMM, Libro XVII; 1718-1725).

Pasarían tres años, antes de que la falta de lluvias se volviera a manifestar en la capital, lo que se tradujo en una rogativa pro pluvia de nivel III el 14 de junio de 1723 (AACM, vol. 49-A; 1723), sin que se obtuvieran los resultados esperados, por lo que un mes después se ordenaba un nuevo ceremonial pro pluvia de nivel III (ACCM, Libro 30; 1722-1727, 13-VII-1723). Pasando dos años sin mayores sobresaltos, hasta que el 13 de julio de 1725, se denunciaba en Puebla esterilidad de los tiempos y carestía de ganados (AHMP, vol. 41; 1723-1728). Un invierno y primavera secos hicieron sonar las alarmas en México, tan pronto como el 6 de mayo, fecha en la que fue solicitado un ceremonial pro pluvia de nivel V (AACM, vol. 52-A; 1726), documento que también atestigua la presencia de enfermedades. El resto de la década, al parecer, fue bastante apacible. 
Hasta agosto de 1730 se manifestó de nuevo una falta grave de lluvias, en este caso en Morelia, donde se organizó un ceremonial pro pluvia de nivel IV (ACMM, Libro XVIII; 1725-1734, 1-VIII-1730). Tres años habrían de pasar para que la escasez de precipitaciones obligara a la realización de rogativas pro pluvia en la capital con un ceremonial de nivel IV (AACM, vol. 59-A; 1733-1734, 29-VIII1733). De este extracto se destaca la precisión con que se describe el evento que les afectó, el cual, sin duda, es lo que comúnmente se conoce como canícula en México, Centroamérica y el Caribe:

... para saber la disposición de plegaria que se hace a Nuestra Señora de los Remedios, que está conferida con el excelentísimo seńor Virrey y con el excelentísimo señor Arzobispo, para que su Divina Majestad interceda con su preciosísimo hijo nos socorra con las aguas que se han levantado y se pierden los campos, así de semillas, como de ganados y cunden las enfermedades... (se propone como rogativa pro pluvia de nivel IV).

Tales alteraciones climáticas parecen haber influenciado a vectores epidémicos, que en el otoño de 1733 dieron lugar a una de las peores epidemias, entre las que asolaron a la ciudad de Puebla durante el virreinato (AHMP, Libro 43; 1733-1738, 28-X-1733). La primavera siguiente debió ser bastante seca, ya que para el 18 de junio se denunciaba dicha situación, además de las enfermedades que afectaban a la capital. El ceremonial de rogativa (de nivel III) y la advocación elegida (la virgen de Loreto) nos dicen que lo que más les preocupaba eran las enfermedades, siendo secundaria la necesidad de lluvia (AACM, vol. 59-A; 17331734, 18-VI-1734). Para 1735, también la capital se describe una fuerte canícula, aunque más temprano en el año que la descrita en 1733 (AACM, vol. 60-A; 1735, 20-VII-1735):

El señor Conde del Valle dijo que las lluvias obviado y por su falta se pierden los campos y se experimentan enfermedades y muertes y que se deben hacer plegarias y deprecaciones, como se acostumbra en semejantes necesidades. Y tratado y conferido y que este mes y el próximo de agosto es preciso y necesario de las aguas y que estas se han alzado, atrasándose los campos y sobreviniendo enfermedades y muertes y que en semejantes casos es el remedio y consuelo el ocurrir con plegarias a la Milagrosísima Imagen de Nuestra Señora de los Remedios; se acuerda se le haga en su santuario... (rogativa pro pluvia de nivel IV). 
Para 1736 es Puebla la urbe que denuncia una fuerte canícula, la cual dio lugar a una rogativa pro pluvia de nivel IV (AHMP, Libro 43; 1733-1738, 7-VIII1736). Unos meses después las epidemias hicieron sus estragos en las ciudades de México y Puebla, generando rogativas de nivel III y nivel V (ACCM, Libro 34; 1736-1737, 26-I-1737 y 22-II-1737, y AHMP, Libro 43; 1733-1738, 11-IV-1737, 7-V-1737, 28-VI-1737, 9-VII-1737 y 13-VII-1737). La peste, que al parecer se extendía por toda la Nueva Espańa, también dejó su impronta en Morelia (AHMM, Libro 2; 1616-1739, 11-X-1737).

El año de 1739 fue terrible. La Ciudad de México condujo dos ceremoniales pro pluvia de nivel III, tanto el 14 de mayo como el 26 de junio. El primero bajo el patronazgo de la virgen de Los Remedios, y el segundo bajo la imagen de San Isidro Labrador (AACM, vol. 64-A; 1739). Estos mismos extractos dan cuenta de la presencia de heladas, en una época del año tan inusual para este tipo de fenómenos. Morelia y Puebla también informaron de tan aciago evento; en la primera ciudad, en julio de 1739 se solicitó la realización de un ceremonial pro pluvia de nivel V (AHMM, Libro 21; 1735-1741, 9-VII-1739 y ACMM, Libro XIX; 1734-1743, 10-VII-1739), mientras que la segunda urbe reportaba en noviembre carestía de bastimentos (AHMP, Libro 44; 1739-1742, 14-XI-1739), la cual continuó a lo largo de 1740 (AHMP, Libro 44; 1739-1742, 22-VI-1740 y 17-XII-1740). Ese mismo año se reportó en Morelia un fin de estación de lluvias muy seco, lo que dio lugar a una rogativa pro pluvia de nivel V (ACMM, Libro XIX; 1734-1743, 22-IX-1740).

Desafortunadamente, el año siguiente (1741) no fue mejor, invierno y primavera secos hicieron temer lo peor, y en fecha tan temprana como el 21 de abril se pidió la celebración de rogativas pro pluvia (AACM, vol. 66-A; 1741), a lo que se respondió, el 4 de mayo, que se haría una rogativa a la virgen de Los Remedios en su santuario (rogativa de nivel III) y una a San Antonio de Padua en Tlatelolco (rogativa de nivel II). En Morelia este año también se manifestó seco, por lo que para el 22 de julio se acordó la conducción de un ceremonial de rogativa pro pluvia, el cual por sus características se define de nivel IV (ACMM, Libro XIX; 1734-1743). El invierno y la primavera subsiguientes debieron ser muy secos, ya que para el 28 de mayo de 1742 se autorizaba una rogativa pro pluvia en el santuario de la virgen de Los Remedios (AACM, vol. 67-A; 1742), la cual el 4 de junio subía a categoría $\mathrm{V}$, ante una situación que se agravaba conforme corrían los días. El archivo de la catedral de México también da cuenta de este acontecimiento, por lo que el 29 de mayo reportó la solicitud de rogativa, y el 8 de junio confirmó el enaltecimiento de la misma (ACCM, Libro 36; 1742-1743). Por lo acotado en estos extractos se hablaba de falta de lluvias por todo el reino de la Nueva Espańa. Los eventos de aquellos años debieron impactar fuertemente a 
las autoridades eclesiásticas, ya que el 7 de junio de 1743 decretaron la realización de una festividad anual a san Primitivo, como medida precautoria en caso de tiempos secos (ACCM, Libro 36; 1742-1743), con misa en su capilla y procesión alrededor de la iglesia.

El siguiente año (1744) tampoco pintó mejor en cuanto a buenos temporales, teniéndose que solicitar una rogativa pro pluvia el 6 de junio (ACCM, Libro 37; 1744-1745), en esta ocasión bajo el patrocinio de san Primitivo, ceremonial que por su pompa se define de nivel III. Morelia y Puebla manifestaron falta de lluvias y de bastimentos en 1745 . En el caso de la primera ciudad incluso tuvo lugar un ceremonial pro pluvia de nivel III (ACMM, Libro XX; 1744-1748, 15-VII1745 y AHMP, Libro 46; 1745-1748, 27-VIII-1745). La racha de malos años llegaba a tres seguidos en 1746: para abril el maíz escaseaba en Puebla (AHMP, Libro 46; 1745-1748, 14-IV-1746), y un mes después (12-V-1746) se denunciaban escasez de lluvias, epidemias y "grave daño en las labores", por lo que se solicitaba un ceremonial de rogativa pro pluvia (nivel IV), dándonos a conocer información contenida en este mismo libro de actas de cabildo que el 27 de mayo se cancelaba cualquier evento religioso para pedir lluvia ya que había comenzado a llover de manera copiosa. Sin embargo, en la vecina cuenca de México la dicha duró poco, pues el 11 de agosto quedó acotado que hacía más de un mes que no llovía, por lo que se condujo una rogativa pro pluvia (nivel IV) con el favor de san Primitivo (ACCM, Libro 38; 1746-1747).

1747 no dio muestras de fuerte ausencia de precipitaciones, pero si hay reportes de epidemias en la capital y Puebla, habiéndose conducido rogativas para apaciguarlas, de nivel IV en el caso de Puebla y de niveles III y IV en la Ciudad de México (AHMP, Libro 46; 1745-1748, 20 -VI-1747, y ACCM, Libro 39; 1747-1749, 11-VII-1747 y 12-VIII-1747). Las ciudades del centro-sur de México tuvieron un respiro durante un año, para sufrir de nuevo en 1749 inclemencias causadas por los azotes del tiempo: en Morelia el 2 de junio se acordó una rogativa pro pluvia de nivel IV, la cual no rindió los frutos esperados y para el 15 de julio hubo que patentizar un ceremonial pro pluvia de nivel $\mathrm{V}$, solicitando el favor de la virgen de Los Urdiales (ACMM, Libro XXI; 1748-1751). Advocación a la que a partir de entonces se le concedió el patronazgo de los ceremoniales pro pluvia de mayor relevancia en la capital michoacana. En la capital no se encontraron registros de rogativa para este año, pero un documento del ayuntamiento, fechado en $17 \mathrm{de}$ noviembre, da cuenta de la pérdida de la mayor parte de las cosechas (AACM, vol. 74-A; 1749).

Los inicios de la década de 1750 fueron bastante calamitosos, y de acuerdo con un documento del cabildo de la catedral de México, los dos años anteriores 
habían sido tan escasos de lluvias que "experimentó este reino tan cortas cosechas, que apenas pudieron sufragar para el abasto de las más populosas ciudades". Por ello este cabildo impulsó la celebración de una rogativa de nivel III, el 13 de mayo de 1750, bajo la advocación de san Primitivo (ACCM, Libro 40; 1750-1751, 13-V-1750). Más tarde, en junio, ambos cabildos ordenaron sendas ceremonias de rogativa pro pluvia (nivel V), solicitando el favor de la virgen de Los Remedios (AACM, 75-A; 1750, 12-VI-1750 y ACCM, Libro 40; 1750-1751, 14-VI-1750). Tan grave era la situación que el virrey intervino en la correspondencia que se daba entre cuerpos de gobierno, para oficializar un ceremonial de rogativa, ya que como se asienta en estos documentos, la falta de lluvias no sólo afectaba a la capital sino había sido especialmente marcada "Tierra Adentro", es decir, los altiplanos central y septentrional de México. La preponderancia de la virgen mexicana, la de Guadalupe, sobre la virgen gachupina, la de Los Remedios (que permaneció como patrona de la capital hasta la imposición de las leyes de Reforma), hacia mediados del siglo XVIII era más que evidente, debido a que a la primera ya se le consideraba "patrona universal de este reino", y por tanto, en su nombre, se organizaron ceremoniales de rogativa pro pluvia (nivel IV) por la falta de lluvias tanto en la capital y sus alrededores, como "Tierra Adentro" (ACCM, Libro 40; 1750-1751, 18-VIII-1750). Ante la escasez provocada por la esterilidad de los años anteriores y un invierno e inicio de primavera secos, en Puebla, en 1750, se realizó una rogativa pro pluvia (nivel IV) tan pronto en el año como el 16 de abril (AHMP, Libro 47; 1749-1754).

Casi un año después, Puebla repitió un ceremonial similar, pero esta vez de nivel V (AHMP, Libro 47; 1749-1754, 23-IV-1751), agregándose una procesión, para los mismos fines, el 5 de mayo. Se manifestaba en estos extractos que, además de la falta de lluvias, la ciudad también estaba amenazada de enfermedades. Por las mismas fechas se reportaba en la capital la presencia de "escarchas", que habían beneficiado a los trigos, pero que habían perjudicado a los maíces (ACCM, Libro 40; 1750-1751, 16-IV-1751). El respiro ante las calamidades meteorológicas duró sólo dos años, habiéndose exaltado la realización de rogativas pro pluvia (nivel III y V) el 30 de julio de 1753 ante lo que parecen ser indicios de canícula; sin embargo, los datos recabados apuntan a que dichos ceremoniales no llegaron a consumarse (AACM, 78-A; 1753).

Dos años más de comportamientos climáticos dentro de la norma fueron interrumpidos durante la primavera de 1755 , ya que tanto en la capital como en Puebla se hizo necesario recurrir a rogativas pro pluvia de nivel V, en la primera ciudad, y de nivel IV en la segunda (ACCM, Libro 42; 1753-1756, 6-VI-1755 y AHMP, Libro 48; 1754-1757, 11-VI-1755). El siguiente año (1756) no fue más 
benevolente, y ambas ciudades se vieron afectadas de nuevo por la falta de lluvias durante el invierno y la primavera. Lo anterior motivó la conducción de un ceremonial de rogativa pro pluvia nivel IV en Puebla (AHMP, Libro 48; 1754-1757, 18-V-1756) y la propuesta de un ceremonial similar en la capital, el cual no llegó a celebrarse (AACM, 80-A; 1756, 8-V-1756).

El resto de la década fue tranquilo, hasta que la primavera de 1759 se manifestó seca en Morelia, y las rogaciones por las lluvias se hicieron necesarias (nivel III), habiéndose asentado estos ceremoniales el 18 de junio (ACMM, Libro XXIV; 1757-1759). Para infortunio de los michoacanos, las precipitaciones volvieron a escasear al final del verano, por lo que el dean de la catedral expuso que el obispo se encontraba de acuerdo con que se condujese un ceremonial de rogativa pro pluvia (nivel IV), ceremonial que inició el 17 de septiembre (ACMM, Libro XXIV; 1757-1759). Tan mala era la situación en este obispado que el 25 de septiembre se preguntaba de qué manera se podría colectar el diezmo ante la mortandad de ganados (ACMM, Libro XXIV; 1757-1759). Pero, al parecer, 1759 fue todo menos homogéneo en su comportamiento meteorológico, ya que tanto la capital como Morelia dan cuenta de fuertes precipitaciones, la primera en el mes de mayo (ACCM, Libro 44; 1759-1762, 21-V-1759) y la segunda en el mes de octubre (ACMM, Libro XXV; 1759-1762, 9-X-1759). En el caso de Morelia quedó constancia de una rogativa pro serenitatem (nivel IV).

Dos años sin sobresaltos fueron interrumpidos de manera dramática, al final de la primavera de 1761, en tanto que las tres ciudades que se tratan tuvieron que realizar sendos ceremoniales de rogativa pro pluvia:

1. Ciudad de México: "Procurador General dijo que respecto a experimentarse, no sólo en esta capital y comarca, sino en toda la Tierra Adentro, falta de lluvias, por lo que podría sobrevenir escasez de semillas y la más principal de maíz y también la de mortandad de ganados por la mucha seca y enfermedades y aunque ha llovido algo, ha sido en manchones y en diversas haciendas el daño de granizo, en que los labradores han perdido mucho trigo; con muchos otros accidentes que pueden sobrevenir, por lo que se haga una depresación o novenario a la milagrosísima imagen de Nuestra Señora de los Remedios, trasladándose de su santuario a esta Santa Iglesia Catedral y concluido se restituya a su santuario, descubriéndose el Divino y Santísimo Sacramento y haciéndose plegarias en todas las iglesias..." (AACM, 82-A; 1761, 17-VI-1761). Tal ceremonial corresponde a rogativas de nivel V. Por su parte, el cabildo de la catedral, además de ser coparticipe de los anteriores ceremoniales, condujo una 
rogativa pro pluvia (nivel IV) el 9 de junio, bajo el amparo de san Primitivo (ACCM, Libro 45; 1761-1762).

2. Morelia: “... habiendo propuesto el señor Dean que en atención ha haberse la enfermedad y ser notable la escasez de lluvias, le parecía a su Ilustrísima el que se sacase en procesión por la plaza, la soberana Imagen de Nuestra Señora de Guadalupe y que se cantase misa solemne de rogativa el jueves, que se contarán once del corriente... se le pase recaudo al Alcalde Mayor para la asistencia de la ciudad y a los RRPP prelados de las sagradas religiones... y que se aseen las calles por donde ha de ir dicha procesión... que todo se haga con la devoción y solemnidad que demanda este acto de religión..." (ACMM, Libro XXV; 1759-1762, 9-VI-1761). Se trató de un ceremonial de rogativa pro pluvia de nivel IV. Quince días después (26-VI-1761), se propugnaba por la celebración de rogativas pro pluvia de nivel $\mathrm{V}$, con el favor de la virgen de Los Urdiales, las cuales comenzaron a realizarse el día 30.

3. Puebla: “... respecto del novenario que se solemnizó a la soberana imagen de Jesús Nazareno por la falta de lluvias, no se haría asequible la consecución de las dos funciones, en los días 9 y 10..." (AHMP, Libro 50; 1760-1761, 6-VII-1761). Se trató de un ceremonial pro pluvia de nivel V, en tanto que la mencionada imagen fue trasladada en procesión desde su iglesia.

El otoño, invierno y primavera siguientes, dan cuenta de epidemias en las ciudades de Puebla, México y Morelia, manifestándose dichos episodios virulentos en ese orden: Puebla, rogativa de nivel V, ordenada su ejecución el 24 de octubre de 1761 (AHMP, Libro 50; 1760-1761). En la capital la epidemia se manifestó de febrero a mayo de 1762 (ACCM, Libro 45; 1761-1762), habiendo sido necesario realizar una rogativa de nivel $\mathrm{V}$ el 8 de marzo de 1762 con miras a atajar esta amenaza. La correlación entre morbilidad y tiempos secos y calurosos queda explicada en el siguiente extracto, fechado en la catedral de México el 22 de abril de 1762 (ACCM, Libro 45; 1761-1762):

... considerando que lo principal de esta epidemia era ser fiebres ardientes y pestilentes y que a esto continuaba la ardentía del tiempo y excesivas calores, lo que lloviendo, podría experimentarse, el que esto se aplacarse, se expresó que también con el novenario del Santísimo Sacramento, se podría sacar al público y ponerse en el Altar Mayor la reliquia del señor San Primitivo, cuyo patrocinio para que lloviese tan experimentado es... (rogativa pro pluvia de nivel III). 
Un mes después, al no cejar la epidemia, se decretaba la conducción de rogativas de nivel V, bajo las imágenes de las vírgenes de Guadalupe y Loreto (ACCM, Libro 45; 1761-1762, 22-V-1762). En Puebla, de nuevo ese mes de mayo, hubo que llevar a cabo rogativas de nivel IV y $\mathrm{V}$ al continuar los decesos y contagios de sus habitantes en gran número (AHMP, Libro 51; 1762-1765, 7-V-1762). A su vez, por ese entonces, Morelia se vio en la necesidad de organizar una rogativa de nivel $V$, ya que la epidemia, finalmente, la había alcanzado (ACMM, Libro XXV; 1759-1762, 10-V-1762). Misma que en la capital de Michoacán se seguía manifestando un ańo después, pues el 26 de abril de 1763 quedó asentada una rogativa de nivel V contra la peste (ACMM, Libro XXVI; 1763-1765). Este año de 1763 resultó bastante inestable en Morelia, tanto en términos mórbicos como meteorológicos, pues la documentación indica que esta ciudad fue víctima de una fuerte canícula hacia principios de agosto, lo que motivó la oficialización de un ceremonial pro pluvia de nivel V el 9 de agosto (ACMM, Libro XXVI; 1763-1765).

Dos ańos exentos de fuerte variabilidad climática se vieron interrumpidos por un invierno y primavera secos en 1765 , lo que dio lugar a que en la capital se condujeran rogativas pro pluvia de nivel $\mathrm{V}$, en fecha tan temprana como el $17 \mathrm{de}$ mayo (ACCM, Libro 47; 1764-1766, 17-V-1765). Un mes después (16-VI-1765) se devolvió a su santuario a la virgen de Los Remedios, en medio de lluvias generalizadas. El año siguiente (1766) Morelia tuvo una primavera muy seca, ya que el 20 de junio se hizo necesario patentizar un ceremonial pro pluvia de nivel V (ACMM, Libro XXVII; 1766-1768). Más severo resultó 1767, por tanto, para el 4 de junio se oficializaba en la capital una rogativa pro pluvia de nivel V (ACCM, Libro $48 ; 1766-1768)$. Para fortuna de todos los que poblaban la cuenca de México por aquel entonces, estos mismos documentos dan cuenta que para el 17 de junio se decretaba la restitución por la mañana de la virgen de Los Remedios a su santuario, ya que las lluvias se habían generalizado por las tardes. En Morelia también se resintió falta de lluvias en fechas similares, lo que desembocó en la necesidad de realizar rogativas pro pluvia de nivel IV a partir del 22 de mayo (ACMM, Libro XXVII; 1766-1768). La virulencia de la seca queda manifiesta en esos mismos extractos, al aducirse que en ese momento, para la ciudad de Morelia, resulta más importante pedir por la lluvia que conducir con todo su esplendor la conmemoración de Corpus Christi o los funerales de la reina.

Como se ha podido observar, la década de 1760 resultó entre las más funestas, no sólo del siglo XVIII sino de la serie climática propuesta, y sus dos últimos años no fueron la excepción: 
1. (1768), Ciudad de México, “... estaba determinado el que hiciese un novenario a la Santísima Imagen de Nuestra Señora de los Remedios por la escasez de aguas, como por lo que se iba extendiendo la enfermedad del sarampión, por lo cual se debería traer la Santísima Imagen de su santuario por parte de la ciudad..." (ACCM, Libro 49; 1768-1769, 10-VI1768). Ceremonial pro pluvia de nivel V.

2. (1769), Morelia, “... hallarse su señoría Ilustrísima el obispo, mi señor, muy inclinado a que se trajera Nuestra Señora de los Urdiales cuanto antes a esta Santa Iglesia, como se había hecho en los antecedentes años y que no habiendo otro día más desembarazado, ni pronto, que el domingo 21 del corriente por la tarde, a que se agregaba estar el lunes, asimismo, desocupado para dedicarle la misa acostumbrada..." (ACMM, Libro XXVIII; 1768-1770, 19-V-1769). Se trató de un ceremonial pro pluvia de nivel IV. Extractos de este mismo libro, fechados el 20 de junio y el 11 de julio, dan cuenta de una extrema escasez de trigo. Pero las penurias de ese ańo no terminaron en Morelia a fines de la primavera, ya que para el 4 de agosto (AHMM, Libro 28; 1759-1771) se oficializaban rogativas pro pluvia de nivel V. Por su parte, en Puebla se denunciaba, al final de la primavera, la pérdida de las cosechas de trigo de invierno por causa del chahuixtle (AHMP, Libro 52; 1766-1769, 12-VI-1769), así como, en el verano, la presencia de tiempo seco, de tan funestas consecuencias a esas alturas del año, por lo que se decretó un ceremonial pro pluvia de nivel IV (18-VIII-1769).

El inicio de la década de 1770 no pintó mejor en cuanto a extremos meteorológicos; así, su primer año fue bastante funesto en las ciudades de México y Morelia. La capital tuvo que conducir un ceremonial pro pluvia de nivel V (ACCM, Libro 50; 1769-1770, 21-VI-1770). Para fortuna de esta ciudad, otro extracto de este mismo libro, y fechado el 2 de julio, da testimonio de lluvias; “... que ya se han entablado..." de forma cotidiana cada tarde. Por su parte, Morelia se vio obligada a perpetrar, muy tarde en el año, un ceremonial pro pluvia de nivel V (AHMM, Libro 32; 1769-1772, 22-IX-1770). Ese mismo año, en Puebla, se hicieron rogativas por causa de un fenómeno prácticamente inexistente en el México central, la plaga de langostas (AHMP, Libro 53; 1770-1772, 13-VII-1770). Esta misma ciudad reportaba el 20 de septiembre escasez de maíz en su alhóndiga (AHMP, Libro 53; 1770-1772). 
El año de 1771 fue también deficitario en precipitación en las ciudades de México y Puebla. En la primera se realizó una rogativa pro pluvia de nivel V, que terminó su novenario el 18 de mayo (ACCM, Libro 51; 1771-1772, 7-VI-1771). Al no surtir efecto, el ayuntamiento clamó por poner fin a la falta de lluvias y enfermedades, así como atajar la presencia de "hielos" con un nuevo ceremonial pro pluvia de nivel V (AACM, 91-A; 1771, 29-V-1771). Sin embargo, la rivalidad entre el cabildo civil y el cabildo eclesiástico hizo que no se pudiese traer a la virgen de Los Remedios, y el cabildo civil tuvo que solicitar de nuevo el 28 de junio una rogativa pro pluvia de nivel V, bajo el patronazgo de la virgen de Guadalupe, la cual se verificó hasta el 23 de julio. Por su parte, en Puebla, el 6 y el 24 de junio se tuvieron que conducir ceremoniales pro pluvia de nivel V (AHMP, Libro 53; 1770-1772). En ese mismo extracto se especifica que para el 10 de julio seguía sin llover.

Las cosas no mejoraron en 1772, por lo que las ciudades de México, Morelia y Puebla tuvieron que conducir ceremoniales rogativa pro pluvia en diversas fechas:

1. México: "Por lo adelantado de la estación y la extensa falta que hace el agua, así para la salud de los habitantes de esta ciudad, como para beneficencia del campo en sus sementeras, se hace preciso implorar los divinos auxilios para el socorro de las lluvias que tanto se necesitan... disponga que inmediatamente se baje a esta capital la santísima imagen de Nuestra Señora de los Remedios, a fin que se hagan el novenario y rogaciones acostumbradas en semejantes casos..." (AACM, 92-A; 1772, 4-V-1772 y ACCM, Libro 51; 1771-1772, 3-V-1772). Lo temprano de esta rogativa pro pluvia de nivel $\mathrm{V}$ brinda la oportunidad de calibrar la magnitud del capítulo seco del año de 1771.

2. Morelia: “... que el alcalde mayor a nombre de la ciudad, le había visto para que se hiciera alguna deprecación por la escasez de aguas que se experimentaba y demasiado calor, y que a su señoría le parecía el que se podía traer el día de mañana por la tarde en procesión a esta Santa Iglesia desde el convento de La Merced a Nuestra Señora de los Urdiales, como patrona jurada para el efecto, manteniéndose en ella todo el tiempo que parezca necesario y haciéndose la deprecación..." (ACMM, Libro XXX; 1772-1774, 3-VI-1772). Ceremonial de rogativa pro-pluvia de nivel V. Desafortunadamente, para la capital de Michoacán las lluvias volvieron a escasear para agosto y el 12 de ese mes, por lo que se determinó la realización de una rogativa pro pluvia de nivel IV y varias de nivel III (ACMM, 
Libro XXX; 1772-1774). Extractos de ese mismo libro del cabildo de la catedral de Morelia dan a conocer que entre mediados de agosto y principios de octubre hubo lluvias.

3. Puebla: “... a fin de que se traigan a esta Santa Iglesia Catedral las imágenes de Jesús Nazareno y Nuestra Señora de la Soledad a quienes se les haga un novenario de rogación, así por las lluvias, esterilidad del tiempo y peste..." (AHMP, Libro 53; 1770-1772, 27-V-1772). Siendo este un ceremonial pro pluvia de nivel $\mathrm{V}$.

1773 fue un año que se manifestó seco en la capital y en Puebla. En el caso de la primera ciudad se realizó una rogativa pro pluvia de nivel III el 24 de mayo (AACM, 93-A; 1773). En esos documentos se argumenta también la presencia de heladas unos días antes, así como los impedimentos del cabildo eclesiástico para conducir un ceremonial más elaborado. Para el 4 de junio, se daba cuenta de que las lluvias habían comenzado de forma regular. Desafortunadamente, la dicha no duró, y para el 23 de agosto (AACM, 93-A; 1773) se asentó el haberse celebrado una rogativa pro pluvia de nivel $\mathrm{V}$ a la virgen de Los Remedios durante ese mes, y que a pesar de ello, las lluvias seguían sin manifestarse y las enfermedades no cejaban. Por lo tanto, se planteaba la necesidad de organizar nuevos actos de rogación de nivel V, proponiéndose a las imágenes del Señor Crucificado de Santa Teresa o a la virgen de Guadalupe como posibles advocaciones que rigieran estas celebraciones. Por segunda vez, en un lapso de dos años, las tradicionales rogativas pro pluvia a la virgen de Los Remedios no daban los resultados esperados. Situación que fue común durante fines del siglo XVIII y principios del XIX. La fuerte canícula de agosto de 1773 también fue constatada en Puebla, donde hubo que exaltar el 9 de ese mes la realización de una rogativa pro pluvia de nivel IV (AHMP, Libro 54; 1773-1775, 9-VIII-1773). Ese mismo documento reconoce la pérdida de los maíces del valle del Valsequillo por causa de tan terrible seca, habiendo sido el cultivo de este valle de fundamental importancia para la ciudad de Puebla.

El año siguiente, 1774, al parecer hubo menos estragos, pero la falta de lluvias también se hizo presente. En la Ciudad de México, para el 16 de junio se propuso la conducción de una rogativa pro pluvia de nivel V, la cual no se verificó al haber comenzado a llover por aquellos días (ACCM, Libro 52; 1773-1774, 16VI-1774). La canícula resultó más grave que el retraso en el inicio de la temporada de lluvias, por lo que en México y Morelia se realizaron ceremoniales pro pluvia durante el mes de agosto (AACM, 94-A; 1774, 19-VIII-1774 y AHMM, Libro 36; 1772, 11-VIII-1774). En el caso de la primera ciudad no se dejó constancia del grado de ceremonial, mientras que en la segunda fue de nivel $\mathrm{V}$. 
1775 no dio respiro, y tan pronto en el año como el 16 de mayo, tanto el cabildo civil como el cabildo eclesiástico de la capital decretaron la realización de una rogativa pro pluvia de nivel V (AACM, 95-A; 1775 y ACCM, Libro 53; 17751777). En estos extractos también se destacó la presencia de fiebres así como la participación del virrey en la organización de los ceremoniales en la capital. Lo que nos habla de la relevancia que los ritos de rogativa pro pluvia van ganando en esta profundamente inestable y cruel segunda mitad del siglo XVIII. Un mes después en Puebla (AHMP, Libro 54; 1773-1775, 17-VI-1775) fue necesario conducir una rogativa pro pluvia de nivel IV.

1776 tampoco fue un año bueno en sus condiciones meteorológicas, aunque no parece haber sido particularmente virulento, si lo comparamos con otros años de aquellas décadas: la Ciudad de México tuvo que organizar una rogativa pro pluvia de nivel V el 11 de junio (ACCM, Libro 53; 1775-1777), sin que se reporten mayores trastornos el resto del año. Por su parte, Puebla informaba el 8 de mayo (AHMP Libro 55; 1776-1777) la pérdida de las cosechas de trigo por causa del chahuixtle y otros "quebrantos", que no específica, así como una propuesta de rogativa el 21 de junio sin que se especificara el motivo ni se afirmara si realmente se había ejecutado. Con fecha de 13 de julio se dio constancia de continuas lluvias por parte del ayuntamiento de esta ciudad.

Después de doce años continuos de terribles y prolongadas anomalías climáticas, en 1777 no se registró ningún tipo de desastre provocado por algún evento meteorológico. La calma no duró, por lo que la capital tuvo que conducir un ceremonial pro pluvia de nivel V el 3 de junio de 1778 (ACCM, Libro 54; 17771781), habiendo sido este ceremonial el único reportado ese año en el centro-sur de México. 1779 resultó más funesto: primeramente el 1 de junio el ayuntamiento asentaba en sus actas de cabildo (AACM, 99-A; 1779) el "... haber noticia cierta de que varias haciendas se han helado y lo manifiesta lo contrariado que está el tiempo y a más de esto que es el de la mayor atención para el abasto común; que se está experimentando con la falta de lluvias, crecida enfermedad de sarampión y fiebres...”. Situación que condujo, hacia mediados de junio, a la realización de rogativas pro pluvia y contra las enfermedades de nivel V (ACCM, Libro 54; 17771781, 8-VI-1779). Por su parte, en Puebla se denunciaba el 18 de junio (AHMP, Libro 56; 1776-1783) la esterilidad de los tiempos, habiéndose llevado a cabo un ceremonial pro pluvia de nivel $\mathrm{V}$ a partir del 7 de julio. Asimismo, en noviembre de ese año (6-IX-1779), se denunciaba la escasez de maíces y trigos. Además, las tres ciudades condujeron ceremoniales de rogativa de nivel IV contra las enfermedades, entre enero y noviembre de ese mismo año (AHMP, Libro 56; 1776-1783, 
16-I-1779; ACMM, Libro XXXIII; 1779-1780, 16-XI-1779 y ACCM, Libro 54; $1777-$ 1781, 22-XI-1779).

El siguiente año (1780) tampoco fue benévolo, por lo que el 3 de junio comenzó un ceremonial de rogativas pro pluvia de nivel V en la Ciudad de México (ACCM, Libro 54; 1777-1781, 20-V-1780), mientras que el 17 de junio tuvo lugar el inicio de un rito similar en Puebla (AHMP, Libro 56; 1776-1783). Después de muchos años de desasosiego, 1781, 1782 y 1783 no dejaron huella de alarma meteorológica alguna. El invierno de 1784 trajo consigo una fuerte epidemia a la capital, misma que duró de enero a abril (AACM, 104-A; 1784, 13-I-1784), habiéndose organizado una rogativa de nivel $\mathrm{V}$ contra estos males, el 19 de febrero, pidiendo el favor de la virgen de Los Remedios y otro rito igual, el 22 de marzo, bajo el patrocinio del Cristo del convento de Santa Teresa (AACM, 104-A; 1784). El único registro encontrado para ese año en el que se exponen cuestiones plenamente meteorológicas tuvo lugar en Morelia, hacia agosto (ACMM, Libro XXXV; 1784-1787, 7-VIII-1784), cuando una fuerte canícula se manifestó y, por tanto, hubo la necesidad de generar un ceremonial pro pluvia de nivel V. Posiblemente, esa fue la primera consecuencia de envergadura detectada en territorio novohispano a raíz de las fases eruptivas del volcán Laki en Islandia, las cuales duraron de mayo de 1783 a mayo de 1785 (Thordarson y Self, 1993), y cuyos embates se hicieron sentir, en distintos momentos y muy distintas formas, a lo ancho y largo del planeta. Morelia también denunció la presencia de epidemias durante el invierno de 1785, siendo estas de tal virulencia que por este motivo se organizaron rogativas de nivel IV (ACMM Libro, XXXV; 1784-1787, 24-I-1785) y nivel V (22-II-1785).

El invierno y la primavera de 1785 debieron ser muy secos, pues para el 2 de mayo, en la capital, se solicitaba una rogativa pro pluvia de nivel III bajo el patronazgo de la virgen de Los Remedios (AACM, 105-A; 1785), denunciándose en ese mismo extracto la presencia de enfermedades. Para el 10 de mayo se generó otro documento que detalla lo angustioso de aquella primavera (AACM, 105-A; 1785):

... conferido largamente sobre que siendo como es notorio la retardación de las aguas, los infinitos calores que se están padeciendo, las enfermedades que ya se experimentan en esta ciudad y en muchas partes del reino, la mortandad de ganados por la seca, carestía de víveres y pérdida de las sementeras y clamando ya el pueblo porque se traiga la soberana milagrosa imagen de Nuestra Seńora de Los Remedios, se debe traer a que en la forma acostumbrada se le haga novenario en la Santa Iglesia Catedral para implorar por su soberana intercesión, las divinas misericordias y el remedio de tales necesidades, se acordó que se traiga... 
Tres días después, 13 de mayo, se dio inicio al ceremonial de nivel V (ACCM, Libro 55; 1781-1786) con la intención de contener a estas terribles amenazas.

El año de 1786 fue conocido como el "año del hambre" en la Nueva España, y si 1785 fue especialmente terrible en Morelia, 1786 lo fue en México y Puebla. El cabildo de la capital denunciaba el 16 de marzo (ACCM, Libro 56; 1786-1789): "No obstante las prontas y repetidas providencias que he tomado y constan al público, ya para aplicar remedios y socorrer a donde los han exigido las necesidades, originadas de la escasez de granos, y ya para promover las siembras... En tanto llega esta feliz época, que esperamos de la misericordia del Todopoderoso.... Un mes después del anterior extracto, el 21 de abril, se ordenó una rogativa pro pluvia de nivel $\mathrm{V}$ con el favor de la virgen de Los Remedios. Cabe recalcarse que en estos documentos, además de la falta de lluvias, hay constante mención de graves heladas extemporáneas, como las ocurridas en agosto de 1785, responsables en buena medida de la férrea carestía que se vivía por aquel entonces. Incluso, con fecha del 1 de agosto de 1786 (ACCM, Libro 55; 1781-1786) se generó el siguiente extracto:

Considerándose que el mes de agosto del año próximo pasado fueron las extemporáneas heladas que tanto daño hicieron a las sementeras y que han causado las calamidades y estrecheces y aflicciones que se han padecido y están padeciendo... y que no se repitan las heladas, ni otros accidentes, dignándose de conceder felicidad y buen suceso en los tiempos, se haga en la Santa Iglesia Catedral, Colegiata de Nuestra Seńora de Guadalupe, parroquias y demás iglesias del ordinario una misa cantada... (Ceremonial de rogativa de nivel III).

Asimismo, los achaques de 1786 en la capital incluyeron un capítulo de epidemia durante el otońo (ACCM, Libro 55; 1781-1786, 20-XI-1786), lo que dio lugar a la generación de una rogativa de nivel III. Por su parte, la ciudad de Puebla reconocía el 4 de marzo y el 5 de julio de 1786 la terrible escasez que se padecía aquel año (AHMP, Libro 58; 1786-1789), así como la presencia de enfermedades en abril (19-IV-1786).

La terrible situación vivida durante 1786 en la capital dio lugar al registro de los siguientes extractos a principios de 1787:

... con reflexión de que aunque las noticias públicas aseguran la abundancia de las cosechas de maíces y trigos, se opina están malogrados gran parte de los primeros, con especialidad en algunos territorios por la escasez de aguas en las veces que mas se necesitaban y por las dos heladas del mes de octubre (1786) 
que hicieron mucho estrago en este contorno...; un novenario a la soberana y milagrosísima imagen de Nuestra Señora de Guadalupe, en su mismo santuario y que este se haga así, impetrando por medio de la soberana reina de la salud pública y que cese y no siga ninguna enfermedad, peste o contagio, como por los frutos de la tierra... a fin de alejar en lo posible la escasez y carestía de los alimentos de primera necesidad, se pase por el Santo Oficio del Ilustrísimo Señor Arzobispo para que su paternal celo ordene que en todas las iglesias se hagan algunas preces dirigidas a implorar la piedad divina en las calamidades (AACM, 107-A; 1787, 1-I-1787, 19-I-1787 y 20-I-1787).

Para fortuna de quienes habitaban el centro-sur de México por aquel entonces, todo parece indicar que 1787 y 1788 fueron buenos años. A pesar de ello, cualquier alteración grave en temperatura o precipitación trastocaba precios y mentes, tal y como ocurrió en el otońo de 1788. En un notable extracto en que se cita al sabio José Antonio de Alzate, y resguardado en el ayuntamiento de México (AACM 108-A; 1788, 24-XI-1788), se dio cuenta de “... una noticia pública comunicada por el señor don José Antonio de Alzate y hablando de las heladas experimentadas en principio de octubre, asentado haber sido muy funestos sus efectos en el modo de pensar de las gentes, que en los campos añade; ser mejores los verificados en la cerradura de las trojes....”.

La primavera de 1789 fue seca, lo que hizo saltar las alarmas en la capital, esta vez contra una amenaza real. Por lo que, para el 27 de mayo, se propuso la conducción de una rogativa pro pluvia de nivel $\mathrm{V}$, que al parecer no se verificó (AACM-109-A; 1789). Las ciudades de México y Puebla no tuvieron mayores contratiempos el resto del año, pero para infortunio de Morelia, este no fue el caso: una fuerte canícula, hizo necesario conducir un ceremonial de rogativa pro pluvia de nivel V a partir del 31 de agosto (ACMM, Libro XXXVI; 1787-1789). En pleno novenario de esta celebración se dio noticia de copiosas lluvias (5-IX-1789). Sin embargo, eran tiempos que templaban los nervios a pobladores y autoridades de la capital michoacana, ya que el 16 de septiembre se ordenaba de nuevo la conducción de un ceremonial pro pluvia de nivel IV, secas que no habían cejado para principios de octubre (6-X-1789). El registro de misas de agradecimiento el 29 de octubre (ACMM, Libro XXXVII; 1789-1792), permite percatarse de la presencia de lluvias durante la mayor parte de ese mes, precipitaciones que seguían ocurriendo a principios de noviembre (7-XI-1789).

El año de 1790 fue benevolente en Morelia (ACMM, Libro XXXVII; 17891792, 14-X-1790), no así en la capital, la cual tuvo que recurrir el 20 de abril a una rogativa pro pluvia de nivel III (AACM-110-A; 1790) y el 8 de junio a un 
ceremonial pro pluvia de nivel V. En dicho extracto se menciona, a su vez, la amenaza de heladas, y que estas ya habían ocurrido en Toluca y sus alrededores, así como la presencia de enfermedades. 1791 y 1792 parecen haber transcurrido con tranquilidad, con excepción de una epidemia de viruelas en Puebla durante el invierno de 1791 (AHMP, Libro 60; 1791, 9-II-1791).

Los infortunios comenzaron de nuevo en 1793; México, Morelia y Puebla dieron cuenta de ello. En la primera ciudad se ratificaron ceremonias pro pluvia de nivel III a partir del 7 de junio (AACM-113-A; 1793), mientras que en la segunda ciudad, para el 20 de junio, se tuvieron que organizar rogativas pro pluvia de nivel IV (ACMM, Libro XXXVIII; 1792-1794 y AHMM, Libro 69; 1790-1793, 19VI-1793). Esta última ciudad desistía, el 14 de junio, de hacer rogaciones por la falta de lluvias, en tanto que por aquellos días había comenzado a llover en forma regular (AHMP, Libro 62; 1793). Paralelo a este atraso en el inicio de la temporada de lluvias fue una epidemia de viruelas (24-IV-1793). Por último, ese verano se reportó escasez de granos de maíz en la alhóndiga (27-VII-1793).

1794 fue a su vez un año anómalo, con una primavera muy seca, tanto en la Ciudad de México como en Morelia. El 5 de junio se ordenó la ejecución de un ceremonial de rogativa pro pluvia de nivel V en la capital (ACCM, Libro 58; 1792-1796). Por su parte, Morelia, manifestó un capítulo de escasez de lluvias más amargo, ya que en primera instancia se vieron obligados a conducir un ceremonial pro pluvia de nivel IV el 16 de junio (ACMM, Libro XXXVIII; 1792-1794 y AHMM, Libro 75; 1794-1795, 8-VI-1794), sin que rindiera resultados, por lo que el 5 de julio, se ratificó la conducción de rogativas pro pluvia de nivel V (ACMM, Libro XXXVIII; 1792-1794).

1795 tampoco resultó benéfico en sus primeros meses, por lo que en la capital se impulsó la realización de un ceremonial de rogativa pro pluvia de nivel $\mathrm{V}$ a principios de junio (AACM-115-A; 1795, 8-VI-1795). Finalmente, para el 15 de junio comenzó a llover, por lo que este ceremonial no se llevó a cabo. Lo que resulta interesante del extracto fechado el día 15 es que se manifiesta el cuidado que se debe tener para fundamentar la celebración de una rogativa pro pluvia de gran realce, ya que: "Los señores comisarios de fiestas que pasaron a cumplimentar a su excelencia para la venida de Nuestra Señora de los Remedios, dieron cuenta de haberse respondido que por ahora, podía excusarse, atendida la estación, que no ha dejado de ser ya favorable y que además se evitará la alteración de precios al maíz que con ese motivo pudiera darse. En cuya visita se acordó se suspenda lo mandado hasta nueva ocurrencia...". Como se argumentó en la segunda parte de este trabajo, la incidencia sicosocial, económica y política de los ceremoniales de rogativa era notable. 
En Morelia, además de haberse organizado una rogativa pro pluvia de nivel IV durante el mes de mayo (AHMM, Libro 80; 1795, 20-V-1795), hubo un mayor atraso de las lluvias, por lo que el 21 de junio se empezó a conducir un ceremonial pro pluvia de nivel V (ACMM, Libro XXXIX; 1794-1798, 19-VI-1795 y AHMM, Libro 75; 1794-1795, 17-VI-1795). Para fortuna de esta urbe parece haber comenzado a llover durante el transcurso del novenario, ya que para el día 30 de junio se determinó el traslado de las imágenes de san José y la virgen de Los Urdiales a sus respectivas iglesias. Y se ordenó que dichas procesiones fuesen por la mañana, en tanto que las lluvias ya eran comunes por las tardes. Por su parte, Puebla únicamente reportó durante este año la presencia de "peste" en enero (AHMP, Libro 64; 1795, 13-I-1795). 1796 no tuvo mayores consternaciones, salvo la presencia de una epidemia de viruelas en Puebla, en el otońo de ese año (AHMP, Libro 65; 1796, 11-IX-1796).

1797 volvió a manifestarse adverso. En Morelia, para el 12 de junio, se solicitaba una rogativa pro pluvia de nivel V (AHMM, Libro 83; 1796-1799), y para agosto se volvió a denunciar la falta de lluvias (AHMM, Libro 83; 1796-1799, 8-VIII-1797). No existe constancia de que ambos ceremoniales realmente se llevaron a cabo. A fines de ese ańo, tanto Puebla como la Ciudad de México fueron víctima de una terrible epidemia de viruela (AHMP, Libro 67; 1798, 22-XI-1797 y ACCM, Libro 59; 1796-1799, 17-X-1797 y 10-XI-1797). Estos capítulos epidémicos llegaron a generar ceremoniales de rogativa de nivel IV.

Los dos últimos ańos del siglo XVIII siguieron la norma de la mayor parte de los años habidos entre 1760 y 1800 fueron inestables en términos meteorológicos y acarrearon penurias a los habitantes del centro-sur de México. El año de 1798 manifestó retraso de lluvias en las tres ciudades que aquí se tratan. En orden cronológico estas fueron las respuestas ante tales secas:

1. Morelia: “... suplicando se sacase en procesión al Santísimo Cristo de la Sacristía y se le cantase misa de rogación por la necesidad que hay de las lluvias y buen temporal... que el del miércoles 6 del corriente acordaron sus señorías, que en dicho día fuese la procesión y la misa de rogación...” (ACMM, Libro XL; 1798-1799, 4-VI-1798). Dado el grado de elaboración de este ceremonial, se trató de rogativas pro pluvia de nivel IV.

2. Puebla: "Que estando la presente estación tan seca y siendo por su naturaleza cálida y ardiente por falta de lluvias que templen su región, se va experimentando noción y perjudicial a su público, así por lo respectivo a su salud de sus habitantes que continuando puede originar alguna epidemia o peste... para el remedio de este daño que ya se palpa... las preces 
y oraciones que tiene establecida la Iglesia Católica implorando la intervención de la Madre de Dios... una de estas soberanas imágenes cuya advocación es la de la Conquistadora es especial protectora de la fertilidad de los campos por tener experiencia de que en iguales circunstancias que hemos acudido a implorar sus misericordias las hemos obtenido de luego... los antiguos le dieron el renombre de la Señora de las aguas... el que se le haga novenario público a dicha soberana Señora... (AHMP, Libro 67; 1798, 9-VI-1798). Rogativa pro pluvia de nivel V.

3. México: "En 25 de junio venida de Nuestra Seńora de los Remedios por la escasez de agua, se cantó la primera misa del novenario en la Santa Veracruz... y después se hizo la acostumbrada procesión... El día de inicio del novenario hubo amenaza de lluvias, lo que motivó el inicio del novenario en la Santa Veracruz y traslado de la Virgen en coche...” ACCM, Libro 59; 1796-1799: (24-VI-1798). Rogativa pro pluvia de nivel $\mathrm{V}$.

El año de 1799 también dejó huella en las tres urbes por causa de un severo retraso en las lluvias. De nuevo se ordena lo acontecido en forma cronológica:

1. Puebla: “... la falta que hacen ya las aguas y el daño que puede resultar al público esta seca que se está experimentando... que se haga novenario en la forma que ha sido costumbre... novenario en el convento de San Francisco" (AHMP, Libro 68; 1799, 1-VI-1799). Se trató de un ceremonial pro pluvia de nivel IV.

2. “... y acordado se traiga a esta Santa Iglesia el domingo nueve inmediato por la mañana a Nuestra Señora de los Remedios para hacerle novenario por la escasez de aguas..." (ACCM, Libro 59; 1796-1799, 7-VI-1799). Asimismo se gestionó un ceremonial de nivel V.

3. Morelia: “... el mismo señor Dean hizo presente que la nobilísima ciudad, suplica a nuestro Ilustrísimo Prelado, se haga rogación al Santísimo Cristo de la Sacristía por la escasez de lluvias... a la disposición de este cabildo el día en que se había de ser y oído por sus señorías, acordaron que el sábado 15 del corriente sea en la misma conformidad que se hizo el año pasado...” (ACMM, Libro XL; 1798-1799, 11-VI-1799) y “... el que hasta esta fecha estaba ya el tiempo demasiado avanzado y que todavía no se verificaban lluvias algunas, por cuyo motivo se hacía necesario se implore a Dios Nuestro Señor este socorro tan preciso y necesario... fuesen hacer la súplica de que el santísimo Cristo de la Sacristía, saliese 
como en otras ocasiones, en solemne procesión por las calles..." (AHMM, Libro 83; 1796-1799, 12-VI-1799). Ambos extractos coinciden en que se tramitó en ambos cabildos un ceremonial de categoría IV.

\section{Siglo XIX}

Para realizar el corte entre los siglos XVIII y XIX se ha optado por no hacerlo de acuerdo con la tendencia climática hallada, ya que esta es de muy larga duración, y no se observa disminución en la intensidad y recurrencia de los eventos sino hasta la década de 1830 .

El tránsito de 1799 a 1800 debió ser seco para que en principios de junio, tanto México como Morelia, estuviesen afanadas con la conducción de ceremoniales pro pluvia de nivel V (ACCM, Libro 60; 1800-1802, 9-VI-1800 y AHMM, Libro 90; 1800-1801, 23-VI-1800). El invierno y la primavera de 1801 debieron ser más cruentos, ya que en la primavera de 1801 México, Morelia y Puebla se vieron obligadas a conducir sendos ceremoniales pro pluvia de nivel V:

1. México: "El señor Decano hizo presente que estando para concluir el presente mes no se ha experimentado, el que siquiera hayan amagado las aguas, siendo el tiempo regular en que comienzan, llevando ya muchos días de estar destemplada la atmósfera, como notoriamente se ha sentido, pues en algunos de estos días, sobre haber hecho crudos fríos y helado en algunos, los horizontes se mantienen cubiertos de calimas, originándose en el día excesivos calores y vientos impetuosos por todos rumbos que han hecho causar alguna enfermedad, que no difícil se propague, por lo cual se implora el socorro del Todo Poderoso para la felicidad pública y oportunas lluvias, mediante la intercesión de María Santísima en su milagrosa imagen de Los Remedios" (AACM-121-A; 1801, 27-IV-1801) y “... a tratar sobre la venida de Nuestra Señora de los Remedios a esta ciudad, para hacerle novenario por la escasez de agua y haber acordado, como se acordó, que la entrada de Nuestra Señora de los Remedios sea el jueves inmediato a la Santa Veracruz, para que se traiga procesionalmente el viernes a esta Santa Iglesia..." (ACCM, Libro 60; 1800-1802, 27-IV-1801).

2. Morelia: “... la suma escasez de lluvias que hasta esta fecha se está experimentando y que son de temerse los resultados adversos que necesariamente han de seguirse a una sequedad como la que se está palpando; 
dejándose ver ya las amargas y funestas consecuencias en la mortandad de ganados, escasez de víveres y otras... se sirviera determinar con su Ilustrísima y verificado salga en procesión de rogativa, la santísima Imagen del Señor Cristo de la Sacristía, como ha sido costumbre otras veces a efecto de implorar las lluvias..." (AHMM, Libro 90; 1800-1801, 30-V1801).

3. Puebla: “... la falta que están haciendo las aguas y que por ello se empiezan a perder los campos y a experimentarse en la ciudad alguna enfermedad... a tratar con el venerable señor Dean y cabildo de esta Santa Iglesia Catedral, se haga un novenario a la Santa Imagen de Jesús Nazareno... con el fin de implorar las divinas misericordias..." (AHMP, Libro 70; 1801, 28-V-1801).

La suma de cuarenta años de continuos descalabros por causa de extremos meteorológicos, condujo a solicitar que se llevara a cabo una ceremonia anual, en la capital, a la virgen de los Remedios, con la finalidad de garantizar buenos temporales y buenas cosechas (AACM-121-A; 1801, 20-VII-1801): "Este ayuntamiento, en nombre de su público está obligado a solicitar cuantos beneficios necesite para su consecución, graduando por principal el de las felices cosechas, anuente con lo que sobre esto le propuso su Corregidor en turno, ha hecho actuar el expediente que acompaña a las superiores manos de vuestra excelencia. Por lo que, el que anualmente se traslade de su santuario a esta capital la portentosa imagen de María Santísima en su advocación de los Remedios, con el cristiano fin de implorar su patrocinio por medio de un solemne novenario para el logro de las cosechas, provenidas de las abundantes lluvias en sus debidos tiempos y para darle gracias, si los años en esta estación, por si son regulares. La primera dominica después de la pascua de resurrección, expresa el síndico del común, ser a propósito para la traslación de la Santísima Señora. Su pedimento y el del Procurador General instruyen de los ejemplares que gobiernan en la materia, respecto de otras ciudades y lugares del reino y la certificación acumulada comprueba la repetición con que por el remedio de las necesidades públicas, principalmente, a causa de la falta de aguas, se ha trasladado a Nuestra Señora. Fundado el ayuntamiento en este antecedente ha acordado suplicar a vuestra excelencia, como lo hace, se sirva prestar su superior anuencia para que se fije anualmente, tan oportuna como devota deprecación pública...”.

El año de 1802 de nuevo fue calamitoso para la capital, el 10 de mayo se denunciaba una estación destemplada, es decir, caliente y seca, que a la vez había manifestado heladas (AACM-122-A; 1802), y se solicitaba una rogativa pro pluvia 
de nivel V, con el favor de la virgen de Los Remedios, la cual se oficializó el 11 de mayo (ACCM, Libro 60; 1800-1802). En cuanto a 1803, Morelia fue la única urbe que reportó un evento climático extraordinario; una fuerte canícula a lo largo de agosto, lo que dio lugar a un ceremonial pro pluvia de nivel V, registrado el 8 de agosto (AHMM, Libro 102; 1802-1807), y otro del mismo nivel, asentado en ambos cabildos con fecha del día 29 en el ayuntamiento, y fecha del día 30 en la catedral (ACMM, Libro XLI; 1802-1804).

El trauma causado a la ciudad de Morelia por el evento anterior, así como un invierno y primavera secos, hicieron que en esta ciudad se decretara una rogativa pro pluvia de nivel V, el 26 de abril (AHMM, Libro 102; 1802-1807). Desafortunadamente, el tiempo no mejoró, y el 27 de junio se hizo necesario patentizar la realización de otro ceremonial de nivel V, que comenzó el 30 de junio (ACMM, Libro XLI; 1802-1804, 27-VI-1804). La alarma temprana con respecto a la esterilidad de los tiempos también tuvo eco en la ciudad de Puebla, la cual refrendó el 12 de mayo la ejecución de rogativas pro pluvia de nivel V (AHMP, Libro 73; 1804, 12-V-1804). Para desgracia de esta urbe, el 8 de junio se reportaba que la escasez de lluvias y "rigurosos calores" todavía continuaban. Esta falta de mejoría se puede verificar, a su vez, por lo acontecido en la Ciudad de México el primero de junio, fecha en la que se registró la realización de rogativas pro pluvia de nivel V (ACCM, Libro 61; 1802-1804).

Una primavera muy seca causó alarma en las ciudades de México y Morelia, por lo que en la capital se ordenó un ceremonial pro pluvia de nivel V, el 10 de junio (AACM-125-A; 1805), mientras que en la segunda urbe, el 6 de junio, se autorizó un ceremonial del mismo nivel (ACMM, Libro XLII; 1805-1806). Para fortuna de los habitantes de la parte central de la Nueva España, después de diez años de continuos descalabros por causa de los extremos climáticos vividos, 1806 no dejó huella de catástrofe meteorológica alguna. Al desatarse de nuevo las calamidades, fue la ciudad de Morelia la única afectada en 1807. Para principios de julio una primavera muy seca obligó a los cabildos civil y eclesiástico a organizar rogativas pro pluvia de nivel V (AHMM; Libro 107, 1806-1807, 3-VII-1807 y ACMM, Libro XLIII; 1807-1811, 4-VII-1807). Para desgracia de esta urbe, además del retraso en la llegada de las lluvias se presentó ese año un súbito y temprano fin de las lluvias, habiendo tenido por causa de ello que recurrirse a un ceremonial pro pluvia de nivel V, asentado en los registros de ambos cabildos (AHMM, Libro 107; 1806-1807, 13-IX-1807 y ACMM, Libro XLIII; 1807-1811, 14-IX-1807).

El año de 1808 tuvo un invierno y una primavera muy secos, escasez de precipitaciones que se tradujo en ceremoniales pro pluvia de distinto nivel en las tres ciudades: 
1. México: "Hicieron presentes los señores procuradores generales, las angustias en que se haya penetrada esta ciudad, ya por las fiebres que se han propagado, ya por el demasiado rigor del verano de que desde luego provienen y que ha procedido la demasiada mortandad de ganados por falta de pastos, siendo de temerse mayor si las lluvias se retardan y en tal deplorable situación serán, la hambre y la miseria demasiadamente lastimera y pidieron que respecto a que el refugio y asilo de esta ciudad en sus necesidades ha sido el de la rogación a la portentosa imagen de Nuestra Señora de los Remedios, haciéndola su novenario en esta Santa Iglesia Cated ral" (AACM-127-A; 1808, 28-IV-1808). Rogativas pro pluvia de nivel $\mathrm{V}$, que comenzaron el 5 de mayo; en los mismos documentos se reporta la presencia de "fiebres malignas" y mortandad de ganados.

La situación no mejoró, y para mediados de junio el ayuntamiento generó el siguiente documento: "Excelentísimo Señor, los procuradores, síndico y general dicen que el público no sólo se lamenta ya, sino que se explica con acrimonia y excuperación sobre la tardanza en la venida de Nuestra Señora la Santísima Virgen de los Remedios y es necesario concederle la razón, pues no hemos visto año, sino fue el de ochenta y seis y conocido por el del hambre, en que las lluvias hayan dilatado tanto, de suerte que en el presente es ya segura la esterilidad en las semillas; a más de esto, la mortandad de ganados ha sido monstruosa por el rigor y lo dilatado del verano... si se sabe que han degenerado en dolores de costado, pulmonías y fiebres mortales. En esta capital está acreditado por la experiencia que tardando las lluvias se padecen pestes o enfermedades generales y graves y que el recurso seguro contra tantos males y angustias es el de la divina misericordia por interposición de la portentosa imagen de los Remedios, así vuelven a pedir los procuradores a Vuestra Excelencia, con cuanto encarecimiento es posible se sirva representar nuevamente a la superioridad del Excelentísimo Señor Virrey a fin de que a la posible brevedad tenga efecto la venida de aquella soberana imagen...” (AACM-127-A; 1808, 16-VI-1808 y ACCM, Libro 63; 1807-1809, 19-VI-1808). Dos días después se autorizaron las rogativas pro pluvia de nivel $\mathrm{V}$.

2. Morelia: "Luego mandaron sus señorías, que para impetrar las aguas se saque en procesión la Santa Imagen del Señor de la Sacristía, y se le cante misa de rogación el día de mañana, como se ha hecho otras veces..." (ACMM, Libro XLIII; 1807-1811, 9-VI-1808). Se trató de un ceremonial pro pluvia de nivel IV. 
3. Puebla: “... que en el día está experimentando el público no sólo la epidemia general, que aunque no se ha descubierto con aspectos de peligrosa, es de temer que tomando incremento se haga posible, sino también que por la falta de lluvias y consiguiente indeclinable la pérdida de los campos, de que necesariamente han de resultar la escasez de víveres de primera necesidad, por lo que parece conveniente proponer se celebre un novenario de rogación a la Sagrada Imagen de Nuestro Padre Jesús Nazareno que se venera en la parroquia de San José, conduciéndose al efecto a esta Santa Iglesia Catedral...” (AHMP, Libro 77; 1808, 21-VI-1808). Rogativas pro pluvia de nivel V.

El último año de estabilidad político-militar en la Nueva España, año de 1809, debió tener en Morelia un verano muy irregular en cuanto a precipitaciones y un fin de temporada de lluvias catastrófico, en tanto que, tan tarde como octubre, se vieron obligados a conducir un ceremonial pro pluvia de nivel IV (ACMM, Libro XLIII; 1807-1811, 10-X-1809). El siguiente año (1810) comenzó en Morelia y sus alrededores con fuertes heladas (AHMM, Libro 115; 1810-1811, 16-I-1810). Esta misma ciudad tuvo que recurrir a rogativas pro pluvia de nivel IV a principios de verano (AHMM, Libro 111; 1809-1815, 28-VI-1810 y ACMM, Libro XLIII; 1807-1811, 3-VII-1810). Estos mismos documentos hacen referencia a la presencia de enfermedades y carestía de ganados. Por su parte, la Ciudad de México manifestó la realización de rogativas pro pluvia el 8 de mayo y el 1 de junio, de nivel V en el primer caso y de nivel IV en el segundo (ACCM, Libro 64; 1809-1810). También a principios de junio Puebla suscribió ceremoniales pro pluvia de nivel IV (AHMP, Libro 79; 1810, 8-VI-1810), y en noviembre reportaba una gran escasez de maíz (23-IX-1810).

1811 fue el primer año, después de cuatro años de fuertes anomalías, que no reporta eventos fuera de la norma. La primavera de 1812 fue muy seca en Morelia, lo que orilló a esta ciudad a conducir un ceremonial pro pluvia de nivel V a principios del verano (AHMM, Libro 111; 1809-1815, 20-VI-1812 y 11-VII-1812). Ese otoño Puebla sufrió los embates de la "peste" (AHMP, Libro 81; 1812, 11-XII1812), la cual duró todo el invierno (2-III-1813). En la capital también se manifestó la epidemia y tuvieron lugar rogativas de nivel IV, con el fin de atajarla, los días 30 de marzo y 18 de mayo (ACCM, Libro 66; 1811-1813). Aunque para 1813 no existen registros de ceremonia de rogativa por cuestiones meteorológicas, en Puebla a principios del otoño se reconocía escasez de granos por causa de "las circunstancias del tiempo" (AHMP, Libro 82; 1813, 5-X-1813). 
1814 únicamente dejó registros sobre anomalías ambientales en la capital. Primeramente, el 23 de mayo se denunciaba la presencia de enfermedades, mientras que el día 27 de ese mismo mes se destacaban tanto las dolencias antes referidas como la falta de lluvias (AACM-133-A; 1814). La ejecución de rogativas pro pluvia de nivel IV se logró a partir del día 31 de mayo (ACCM, Libro 67; 18131815, 27-V-1814). El primer año de la terrible fase eruptiva del volcán Tambora en Indonesia, que en Europa provocó el llamado año sin verano (1816), sólo dejó huella en el México centro-meridional, en la ciudad de Puebla, la cual entre junio y agosto se queja de fuertes tempestades y rayos, a tal grado que el 23 de junio se oficializó una rogativa pro serenitatem de nivel V (AHMP, Libro 84; 1815). La fuerza de este evento hizo necesario trasladar la pólvora del Colegio del Espíritu Santo al santuario de Loreto (1-VII-1815 y 25-VIII-1815). Es de nuevo Puebla la única urbe que dio cuenta de vicisitudes climáticas en 1816, pero sólo a través de un extracto que argumenta encontrarse muy húmedas las tierras templadas, y muy secas las tierras cálidas, y en el que también se denuncia la escasa entrada de granos a la alhóndiga de esta ciudad (AHMP, Libro 85; 1816, 10-V-1816).

1817 y 1818, por su errático comportamiento meteorológico, parecen denotar la influencia del episodio eruptivo del volcán Tambora. Cuenta de ello dieron las ciudades de México y Morelia. La primera condujo en 1817 un ceremonial pro pluvia de nivel IV, que transcurrió entre el 13 y el 21 de junio (AACM-136-A; 1817 y ACCM, Libro 68; 1815-1818). Mientras que la segunda se vio en la obligación de llevar a cabo un ceremonial pro pluvia de nivel V, prácticamente en las mismas fechas que la capital (AHMM, Libro 119; 1816-1819; 7-VI-1817). Por su parte, 1818 tuvo una primavera tan seca que la Ciudad de México tuvo que conducir un ceremonial pro pluvia de nivel IV el 29 de mayo (AACM, 137-A; 1818 y ACCM, Libro 68; 1815-1818). Las angustias respecto al tiempo habían comenzado antes en Puebla, por lo que entre el 13 y el 16 de mayo se participó a autoridades y feligreses la ejecución de un ceremonial pro pluvia de nivel IV (AHMP, Libro 87; 1818, 13-V-1818). Esta misma ciudad reportaba en agosto que su pueblo sujeto de Tepexi de la Seda, se encontraba infestado de "fiebres pútridas" (26-VIII-1818). El siguiente invierno y primavera debieron ser bastante anómalos,ya que la Ciudad de México manifestó rogativas pro pluvia de nivel $\mathrm{V}$, llevadas a cabo entre el 30 de mayo y el 8 de junio de 1819 (ACCM, Libro 69; 1818-1821, 30-V-1819).

1820 fue el primer año, después de tres años contiguos y dramáticos capítulos climáticos, que no cuenta con registro alguno a este respecto. Eso sí, la "peste", hizo necesarias rogativas de nivel III y IV en Morelia en mayo de ese año (ACMM, Libro XLVII; 1819-1821, 9-V-1820 y 18-V-1820). Los aprietos comenzaron de nuevo en 1821, y lo seco de la primavera e inicio del verano forzó a la 
ciudad de Morelia a conducir un ceremonial pro pluvia de nivel IV a partir del 11 de julio (ACMM, Libro XLVII; 1819-1821, 4-VII-1821). La capital fue la única de las ciudades bajo escrutinio que dejó algún registro sobre cuestiones climáticas durante el año de 1822. Una fuerte canícula parece haberse presentado a lo largo de agosto, por lo que rogativas pro pluvia de nivel $\mathrm{V}$ fueron conducidas a partir del 2 de septiembre (AACM, 142-A; 1822, 7-VIII-1822, 23-VIII-1822 y 1-IX-1822 y ACCM, Libro 70; 1821-1824, 28-VIII-1822). Entre estos documentos cabe destacar el fechado en 23 de julio, que hace referencia a la adecuación institucional de este tipo de ceremonial al nuevo y efímero régimen político:

... se dé el correspondiente paso con el excelentísimo Jefe Político para captar el debido permiso para el novenario, anunciándole que antes contribuía el Excelentísimo Señor Virrey con un día e ignora el cabildo si, en las actuales circunstancias el señor Emperador tendría a bien contribuir... asimismo ponerse de acuerdo con el señor gobernador de la Mitra para señalar el día en que ha de comenzar el novenario...

Por su parte, Puebla fue la única urbe que presentó registro de problemas ambientales en 1824. Esto durante el verano, por lo que el 6 de agosto se propuso una rogativa de nivel IV contra la "peste" y suplicando por las lluvias (AHMP, Libro 93; 1824, 6-VIII-1824). Por mucho 1825 fue más duro y la rigidez de los tiempos se dejó sentir en las tres ciudades:

1. México: “... que se tomen todas las providencias oportunas a fin de que se traiga a esta capital, con el objeto de hacerle un novenario a Nuestra Señora de los Remedios para implorar su patrocinio en la escasez de lluvias que se experimenta, enfermedades y de más necesidades que son consiguientes por este motivo; previniendo que el señor Gobernador del Distrito se ponga el oficio de estilo, quedando a cargo del Ayuntamiento acordarse con la autoridad eclesiástica y practicar las demás diligencias concernientes al efecto..." . Propuesta de rogativa pro pluvia de nivel V. Que se materializó el 11 de junio, al llevarse a cabo la procesión del santuario de Los Remedios a la parroquia de la Santa Veracruz, iglesia de la que ya no pudo salir, después de su tradicional pernocta en ella, por causa de las lluvias (AACM, 145-A; 1825, 3-VI-1825 y 12-VI-1825).

2. Morelia: “... y enseguida acordaron sus señorías en vista de los tiempos tan crueles, y lo mucho que se retardan las aguas, que el martes inmediato se haga una función solemne al Señor de la Sacristía, implorando 
a su Majestad Divina el buen temporal... se pase oficio al ilustre Ayuntamiento, convidándolo para dicha función y recado al mismo fin...” y “... dio cuenta con un oficio del ilustre Ayuntamiento en que se indica querer dirigir al Dios de las Misericordias sus votos y oraciones por medio de un novenario al Señor de la Sacristía y procesión por las calles públicas, implorando sus auxilios en las presentes calamidades y sus señorías acordaron que comience dicho novenario el día de mañana, en que también sea la procesión antes de la misa...” (ACMM, Libro XLIX; 1825-1827, 11-VI-1825 y 13-VI-1825). Documentos del cabildo civil refrendan la realización de estas rogativas pro pluvia de nivel V (AHMM, Libro 121; 1823-1825, 10-VI-1825 y 12-VI-1825).

3. Puebla: "Este ayuntamiento como interesado en solicitar el remedio de las presentes necesidades, especialmente de la escasez de agua que tanto nos aflige... hacer un triduo a Nuestro Padre Jesús Nazareno en la Santa Iglesia Catedral en los días 12, 13 y 14 del actual... desde la parroquia de San José en procesión de rogación..." (AHMP, Libro 94; 1825, 11-VI1825). Se trató de un ceremonial pro pluvia de nivel IV. En documentos fechados el 28 de julio y el 16 de septiembre también se acota la presencia de fuertes epidemias.

El año de 1826 fue seco, y en la primavera se dejaron sentir los rigores de la falta de agua en la capital, mientras que Morelia dio cuenta de una fuerte canícula:

1. México: “... que se tomen todas las providencias oportunas y de estilo a fin de que se traiga a esta capital a Nuestra Señora de los Remedios para implorar su patrocinio en la escasez de lluvias, enfermedades y demás necesidades públicas, previniéndose al señor gobernador del Distrito se ponga en correspondiente oficio para obtener la debida licencia y que la venida de la santa imagen sea el jueves 8 del presente mes, si se concede el permiso..." (AACM, 146-A; 1826, 2-VI-1826 y 8-VI-1826). Rogativas pro pluvia de nivel V. En el documento fechado el 8 de junio se aclara, asimismo, que en adelante los oficios correspondientes a este tipo de ceremonia serán, a su vez, turnados tanto al gobernador del estado de México como al ayuntamiento de Naucalpan, entidades creadas dos años antes, como consecuencia de la promulgación de la constitución federal de 1824. 
2. Morelia: "A continuación el señor Oñate expuso la necesidad que hay de hacer rogaciones públicas al Señor de la Sacristía, en todo lo conforme a lo hecho en el año pasado, para de este modo impetrar la escasez de agua..." (AHMM, Libro 122; 1824-1826, 29-VIII-1826) y “... se dio cuenta con un oficio del ilustre Ayuntamiento de esta ciudad con el objeto de que se haga un novenario y procesión al Señor de la Sacristía, a fin de conseguir por su mediación los auxilios divinos por el buen temporal... se haga dicho novenario y procesión con la mayor solemnidad por los motivos que se expresan en su citado oficio..." (ACMM, Libro XLIX; 1825-1827, 1-IX-1826). Ceremonial pro pluvia de nivel V.

El invierno y la primavera de 1827 debieron ser muy secos, ya que tan pronto en el ańo, el 27 de abril, se hacía una propuesta de una rogativa pro pluvia de nivel V (AACM, 147-A; 1827), que al parecer no pasó de ser un exhorto. Para fines de la primavera de 1828 se autorizó un ceremonial pro pluvia de nivel V en la Ciudad de México (AACM, 148-A; 1828, 29-V-1828 y 19-VI-1828). Habiendo sido este el único registro hallado para el año de 1828 concerniente a anomalías ambientales. En el mismo, a su vez, se asegura gran escasez de ganados y granos. Por fechas similares, en 1829, se repitió un ceremonial igual (AACM; 1829, 2-VI-1829 y 12 VI-1829), el cual comenzó el 15 de junio. El año siguiente (1830) Puebla fue la única ciudad que manifestó algún tipo de fenómeno climático extremo; la falta de lluvias llevó a proponer el 13 de julio la conducción de rogativas las cuales, al parecer, no se verificaron (AHMP, Libro 99; 1830, 13-VII-1830).

Los años malos no cejaban. 1831 no fue la excepción, las ciudades de México y Puebla dieron cuenta de ello:

1. México: "Se vio la información que el señor alcalde Icaza acompaña con oficio sobre la necesidad de que Nuestra Señora de los Remedios venga de su santuario a esta capital para que se celebre un novenario y se acordó que se impetre la correspondiente licencia del Supremo Gobierno por conducto del señor Gobernador del Distrito..." e "Instruyó el señor Tamayo que fueron comisionados por el señor Presidente con sus excelencias los señores Delmotte y Bezares para acordarse con el cabildo eclesiástico que fue de sentir venga Nuestra Señora el sábado a la Santa Veracruz y el domingo por la tarde a la Santa Iglesia Catedral. Que el novenario comience el viernes de la semana entrante, concluya la víspera de la Pascua del Espíritu Santo y depositada en el Sagrario los tres días 
de ello, se regrese el jueves siguiente..." (AACM; 151-A, 1831, 29-IV-1831 y 4-V-1831). Rogativas pro pluvia de nivel V.

2. Puebla: “... siendo muy excesivos los calores que se estaban experimentando y al mismo tiempo la escasez de lluvias, se veía amenazada la ciudad de una epidemia que casi había comenzado a asomarse, eran muchos los enfermos que había de calenturas... novenario o triduo a las sagradas imágenes de Jesús Nazareno y María Santísima de la Soledad... comisión para ponerse de acuerdo con el Venerable Cabildo Eclesiástico...” (AHMP, Libro 100; 1831, 26-IV-1831).

Al fin, 1832 no dio muestras de azotes meteorológicas; sin embargo, la dicha se vio opacada con epidemias en la primavera de 1832 que motivaron una rogativa de nivel V (AACM, 152-A; 1832, 29-V-1832 y ACCM, Libro 72; 1828-1832, 20-VI-1832). 1833 volvió al patrón común de las últimas décadas, teniendo a la población en ascuas con tiempos muy inestables. A esto cabe agregar ese año la llegada del cólera a México. Morelia manifestó falta de lluvia a fines de la primavera y organizó rogativas pro pluvia de nivel III (ACMM, Libro LII; 1833-1835, 22-VI-1833). A su vez, Puebla se vio obligada a conducir un ceremonial pro pluvia de nivel V, que comenzó el 15 de junio (AHMP, Libro 101; 1832-1833, 29-V-1833 y 13-VI-1833). Las rogativas por la presencia del cólera morbus no son referidas, ya que se es de la opinión que de tener esta epidemia, una conexión con vectores potenciados por extremos de la variabilidad climática, estos son de escala global. Cabe conjeturar sobre la aparición del cólera por medio mundo, cuando venía debilitándose la PEH.

1834 parecía ser un buen año en Morelia, hasta que, a principios de septiembre, las lluvia se esfumaron. Lo que hizo necesario llevar a cabo rogativas pro pluvia de nivel IV (ACMM, Libro LII; 1833-1835, 12-IX-1834 y AHMM, Libro 139; 1832-1834, 18-IX-1834). 1835 es un ańo con claras inclemencias del tiempo en la capital y Morelia. La Ciudad de México condujo un ceremonial pro pluvia de nivel V a fines de la primavera (ACCM, Libro 73; 1832-1836, 4-VI-1835 y AACM, 135-A; 1835, 12-VI-1835). Por las mismas fechas, la capital de Michoacán, autorizaba ceremoniales pro pluvia de nivel IV (ACMM, Libro LIII; 1835-1836, 12-VI-1835 y AHMM, Libro 144; 1834-1835, 14-VI-1835). El año de 1836, al fin, no manifestó anomalía climática alguna y sólo hubieron rogativas por epidemias en Puebla (AHMP, Libro 103; 1836, 14-VI-1836 y 20-IX-1836).

El año de 1837 fue, nuevamente, un año con extremos climáticos adversos, por lo que la ciudad de Morelia tuvo que exhortar la realización de rogativas pro pluvia de nivel IV, las cuales finalmente no se llevaron a cabo por las desavenencias 
entre ambos cabildos (AHMM, Libro 148; 1836-1837, 19-VI-1837 y 21-VI-1837). Por las mismas fechas, Puebla si logró la conducción de ceremoniales pro pluvia, también de nivel IV (AHMP, Libro 104; 1837, 14-VI-1837). Antes en el año, esta misma ciudad había reportado la presencia de epidemias (11-II-1837), situación que reconoció de nuevo, por fechas similares, al año siguiente (AHMP, Libro 105; 1838, 12-II-1838). Un mes después, la capital también era víctima de este tipo de males, y el 27 de marzo se autorizó un ceremonial de nivel $\mathrm{V}$ por este motivo (AACM, 158-A; 1838). Pero si el año había empezado mal en términos mórbicos, se complicó aún más la situación al principio del verano, cuando las lluvias escasearon y cayeron algunas heladas, lo que hizo necesario conducir un ceremonial pro pluvia de nivel IV a partir del 6 de julio (AACM, 158-A; 1838 y ACCM, Libro 75; 1838-1840). Morelia, igualmente, tuvo que recurrir a ceremoniales pro pluvia de nivel IV, a principios de julio (AHMM Libro 152; 1838, 4-VII-1838 y ACMM, Libro LIV; 1836-1838, 10-VII-1838).

La siguiente primavera e inicio de verano (1839) volvieron a presentar un panorama funesto, por lo que México, Morelia y Puebla, registraron ceremonias pro pluvia:

1. México: “... de acuerdo con el Excelentísimo Señor Gobernador del Departamento, en vista de la escasez de lluvias y para evitar los males que por esta causa podrían seguirse, desea se haga un novenario a Nuestra Señora de los Remedios, trayéndose secretamente su portentosa imagen de su santuario a esta Santa Iglesia... desde luego podría determinarse el día de la traslación por lo urgente de la necesidad..." (ACCM, Libro 75; 1838-1840, 18-VII-1839). Rogativa pro pluvia de nivel IV.

2. Morelia: "El señor Márquez pidió se excitara al Venerable Cabildo Eclesiástico para que se haga un novenario al Señor de la Sacristía por el buen temporal, pues ya la escasez de agua está causando muchos perjuicios; se mandó dirigir al Venerable Cabildo Eclesiástico la comunicación respectiva...” y “... de la contestación que el venerable Cabildo Eclesiástico ha dado a la excitación que se le dirigió para que se hiciera el novenario al Señor de la Sacristía por el buen temporal y se contrae dicha contestación a manifestar la buena disposición en que se halla aquel cabildo para obsequiar los deseos de éste; pero que no puede costear la cera, más que la del día que le toca hacer el novenario y no de los siete días restantes. Hubo una ligera discusión y se acordó que de los fondos municipales no se saque más cantidad que la que importe el día de la novena, que le 
corresponde a la corporación...” (AHMM, Libro 153; 1839, 13-VII-1839 y 15-VII-1839). Rogativa pro pluvia de nivel IV.

3. Puebla: “... hacer un novenario a las sagradas imágenes de Jesús Nazareno y María Santísima de la Soledad, con el fin de alcanzar de Dios Nuestro Señor las lluvias de que tanto necesitamos, que mañana mismo han de conducirse para la Santa Iglesia Catedral a dichas imágenes...” (AHMP, Libro 106; 1839, 7-VII-1839). Rogativa pro pluvia de nivel V.

El año de 1840, en términos ambientales, únicamente reportó epidemias, las cuales asolaron Morelia y Puebla (ACMM, Libro LV; 1838-1841, 6-III-1840 y AHMP, Libro 107; 1840, 9-III-1840). 1841 volvió a ser inestable y dejó registro sobre anomalías meteorológicas, al igual que dos años antes, en México, Morelia y Puebla:

1. México: “... atendidas las necesidades públicas, ha dispuesto hoy que hagan un solemne novenario a la santísima imagen de Nuestra Señora de los Remedios... que aunque no está en sus principios oponerse de modo alguno al novenario que se piensa hacer a la santísima imagen de María Santísima de los Remedios, siendo cada día más angustiosas las circunstancias del erario municipal, es de todo pienso imposible que para esta vez se ministren los cien pesos que para los gastos de un día deben ministrarse...” y “... en consideración de la escasez de lluvias proponen al Ilustrísimo Cabildo se proveyera un novenario en la forma acostumbrada...” (18-VII-1841) “... se acordó que el sábado 26 del presente comience el novenario de la forma acostumbrada... que el primero y último día del novenario haya procesión por fuera de la iglesia (AACM, 161-A; 1841, 16-VII-1841 y ACCM, Libro 76; 1840-1842, 16-VII-1841 y 18-VII-1841). Rogativa pro pluvia de nivel $\mathrm{V}$.

2. Morelia: “... en atención a la escasez de lluvias y por otras necesidades públicas, se celebrase un triduo de misas solemnes al Señor de la sacristía para alcanzar de su Divina Majestad el remedio de tantos males...” (ACMM, Libro LV; 1838-1841, 13-VII-1841). Rogativa pro pluvia de nivel III, y "Se leyó un oficio del Ilustre Ayuntamiento, invitando al venerable cabildo para que se hiciera un novenario de misas al señor de la sacristía, sacándolo en procesión... para implorar de su misericordia el auxilio de las aguas, cuya suma escasez causaría los mayores estragos... pidiendo comenzar el novenario el lunes 16 del corriente, en cuyo día se verificaría la procesión". Rogativa pro pluvia de nivel V. 
3. Puebla: “... hacer un triduo a la Santísima Virgen de Guadalupe para alcanzar del Todopoderoso, por su intercesión las aguas que tanto escasean ya...” (AHMP, Libro 108; 1841, 17-VII-1841). Rogativa pro pluvia de nivel IV. Falta de precipitaciones, que a su vez se constata, por extractos posteriores que informan sobre escasez de granos (9-VIII-1841 y 30-VIII1841).

Después de décadas, en las que predominaron años con algún tipo de vicisitud meteorológica, la década de 1840 comenzó a mostrar patrones menos volátiles. Entre 1842 y 1846 no existen rastros de problemas ambientales, salvo "fiebres muy agudas" en las proximidades de Puebla, durante la primavera de 1844 (AHMP, Libro 111; 1844, 19-IV-1844). El año de 1846 tuvo una primavera y un inicio de otoño bastante irregulares. La capital tuvo que llevar a cabo un ceremonial pro pluvia de nivel III el 16 de junio (AACM, 168-A; 1846), mientras que en Morelia se condujo un ceremonial de nivel V, el 9 de octubre, por causa de las heladas (ACMM, Libro LVIII; 1844-1847). La categoría alcanzada por este último ceremonial se puede deber en parte a la invasión norteamericana, ya que quedó asentado que las rogativas eran tanto por causa climática como por la guerra. El resto de la década no presentó ningún extremo meteorológico. En cuanto a lo mórbico, sólo ocurrió una epidemia en la primavera de 1849, la cual se enfrentó con una rogativa de nivel V (ACCM, Libro 82; 1849, 25-V-1849). Ceremonial de máxima categoría que, posiblemente, se logró por causa de un temporal adverso, por la época del año en que se realizó y que también se pidiera por "demás necesidades en los días útiles", permite inferir esta posibilidad.

La de 1850 es la última década en que se pueden construir series climáticas a partir de los registros de ceremonia de rogativa, con excepción de los provenientes de la catedral de Morelia, que llegan hasta la década de 1880. El apaciguamiento de los tiempos ya se deja ver con claridad, por lo que los cuatro primeros años de la década pasaron sin mayores contratiempos, en lo que se refiere a extremos meteorológicos. En 1850 se volvió a manifestar el cólera en México, pero como ya se adujo, esta epidemia no se incluye entre los registros expuestos en estas páginas. No fue sino hasta la primavera de 1854 que la falta de lluvias y excesivos calores se volvieron a sentir. En el caso de la Ciudad de México hubo de recurrir a un ceremonial pro pluvia de nivel IV (AACM, 175-A; 1854, 24-V-1854 y ACCM, Libro 85; 1854-1857, 30-V-1854). En estos documentos también se acredita la presencia de enfermedades causadas por el calor. Por su parte, en Morelia ante una primavera y verano secos, se vieron en la necesidad de celebrar rogativas pro 
pluvia de nivel III y V (ACMM, Libro LXIII; 1854-1856, 23-VI-1854, 14-VII-1854 y 2-VIII-1854, y AHMM, Libro II-35; 1854, 17-VI-1854).

Las adversas circunstancias políticas que enfrentó la iglesia católica, bajo el mandato de los primeros gobiernos liberales, emanados de la revolución de Ayutla, se reflejó en la imposibilidad de llevar a cabo un ceremonial pro pluvia por fuera de la catedral el 31 de agosto de 1856, por lo que se condujo uno de nivel IV (ACCM, Libro 85; 1854-1857). Estando la capital bajo el gobierno conservador de Miramón, se pudo conducir un ceremonial pro pluvia de nivel V, el 31 de mayo de 1859 (AACM, 180-A; 1858-1859). Durante esta etapa también tuvo lugar una rogativa de nivel IV en Morelia, cuyos documentos sólo registran el que se condujo "por las necesidades públicas" (ACMM, Libro LXIV; 1856-1864, 12-VII-1857).

A partir de la década de 1860, los únicos registros encontrados referentes a rogativas pro pluvia son, como arriba se mencionó, los existente en el Archivo del Cabildo de la Catedral de Morelia (ACMM), acervo en el que entre los años de 1860 y 1891 se encontraron siete extractos que dan cuenta de la falta de lluvias:

1. “... oficio del honorable Ayuntamiento, en que invita al venerable cabildo para que se celebre un triduo de misas al Señor de la Sacristía, por haberse retirado las lluvias, y con este motivo amenaza gran peligro a las labores a causa de los hielos... Se acordó contestarle que sin embargo de haberse dado licencia últimamente para un triduo que se verificó por las mismas circunstancias, y de las preces que en todo el temporal de aguas da la Iglesia para impetrar el auxilio divino..." (ACMM, Libro LXV; 18641867, 5-X-1866).

2. “... para que se celebrara un triduo en honor del Señor de la Sacristía por el buen temporal y demás necesidades públicas...” (ACMM Libro LXVI; 1868-1871, 15-VII-1870).

3. “... triduo de misas solemnes en honor de la Sagrada Imagen del Señor de la Sacristía, para implorar la lluvia y el remedio de las demás necesidades públicas...” (ACMM, Libro LXVI; 1868-1871, 28-VIII-1871).

4. “... un ocurso suscrito por varios vecinos de esta ciudad, en que piden licencia para que se celebre un triduo de misas cantadas y preces por la tarde los días 24, 25 y 26 del presente en honor de la Sagrada Imagen del Señor de la Sacristía, con el objeto de impetrar de su divina majestad un buen temporal y el remedio de las demás necesidades que nos afligen... y a nombre de algunos vecinos pedía licencia para que se celebrase un triduo de misas solemnes en honor de la soberana imagen del Señor de la Sacristía por el buen temporal y demás necesidades públicas perma- 
neciendo la imagen en el presbiterio... y accediendo a la súplica... se extiende a quinario el triduo... licencia para que se celebre un triduo de misas solemnes y ejercicio piadoso por la tarde en honor de la soberana imagen del Señor de la Sacristía por el buen temporal..." (ACMM, Libro LXVII; 1872-1876, 22-VI-1875, 18-VII-1875, 21-VII-1875 y 16-VIII-1875).

5. “... licencia para que se celebre un triduo de misas cantadas en honor de la soberana imagen del Señor de la Sacristía en su altar para impetrar el remedio de las necesidades que se experimentan por la tardanza de las aguas, el cual comenzará mañana...” (ACMM, Libro LXVIII; 1876-1881, 10-VI-1876).

6. “... solicitud que hacen algunos vecinos de esta ciudad para que se les permita hacer un triduo de misas cantadas al Señor de la Sacristía después de las del coro y en los días 7, 8 y 9 del corriente, para implorar de su misericordia que nos mande las lluvias que tanto escasean, amenazando con este motivo la pérdida de las sementeras a cuya solicitud se accedió..." (ACMM, Libro LXIX; 1881-1887, 5-VIII-1882).

7. “... varios vecinos y comerciantes de este lugar pidiendo permiso de hacer al Señor de la Sacristía un triduo de misas solemnes, para implorar de su divina majestad el buen temporal y se decretó de conformidad... en consideración a la urgencia por el grave mal que experimentamos a causa de la suma escasez de las lluvias citó este pelicano con el objeto de poner en conocimiento de S.S.I. un ocurso que hacen varios vecinos de este lugar... dedicarle un triduo de misas cantadas después de las de coro en los días 16, 17 y 18 con relaciones entre día y preces por la tarde... solicitan además que tanto la traslación al panteón, como la vuelta después al altar de la Sagrada Imagen, se verifiquen llevándolo en procesión por las dos naves laterales de esta Santa Iglesia con la correspondiente solemnidad..." (ACMM, Libro LXIX; 1881-1887, 27-VI-1884 y 13-VII-1884).

De estos eventos se desprende una menor recurrencia de capítulo secos, que ya se observa claramente desde la década de 1850, como consecuencia del fin de la PEH y, por ende, de su etapa seca, que venía prevaleciendo desde principios del siglo XVIII. Ante la existencia de registros de rogativa pro pluvia en los acervos de la catedral de Morelia, posteriores a 1860, se revisó hasta 1891, año en que comenzaron a tomarse los primeros registros meteorológicos en dicha ciudad (Servicio Meteorológico Nacional). En este punto, cabe recordar que las manifestaciones públicas de la Iglesia fueron prácticamente prohibidas bajo el régimen 
liberal, por lo que los ceremoniales llevados a cabo durante este período no fueron definidos a partir de su nivel de elaboración y pompa.

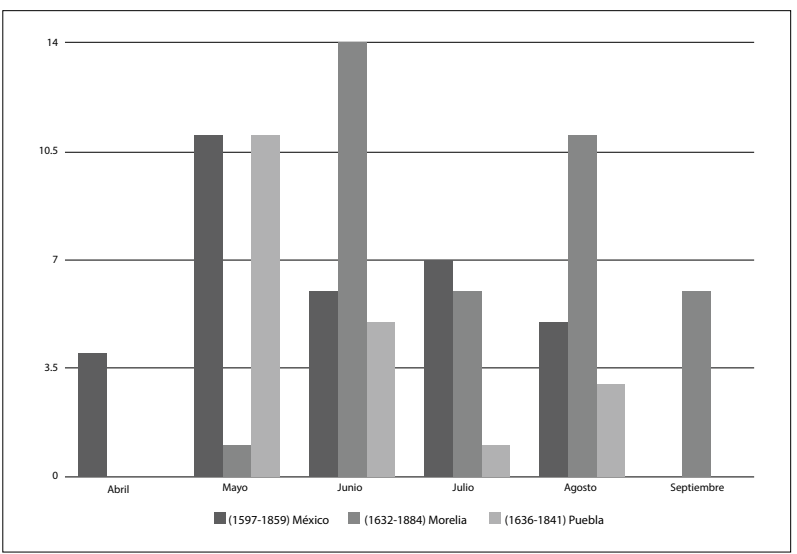

Figura 4. Número de rogativas pro pluvia de nivel IV para las ciudades de México, Morelia y Puebla entre fines del siglo XVI y fines del siglo XIX.

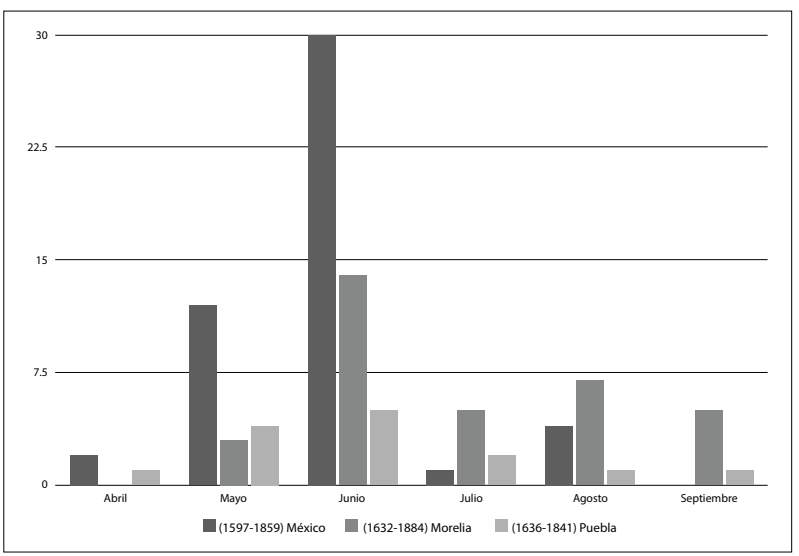

Figura 5. Número de rogativas pro pluvia de nivel $\mathrm{V}$ para las ciudades de México, Morelia y Puebla entre fines del siglo XVI y fines del siglo XIX. 


\section{Capítulo 3. Guadalajara y Oaxaca, comparación de sus datos con los del centro de México}

Los datos obtenidos en la capital del antiguo reino de Nueva Galicia y en la sede obispal de Antequera de Oaxaca son, por mucho, menores a los encontrados en México, Morelia y Puebla. Por tanto, no fue posible generar serie climática alguna, limitándose por tanto la exposición a describir algunos documentos aislados que nos hablan sobre las características ambientales de la Guadalajara virreinal y decimonónica, y algunas de las respuestas culturales llevadas a cabo para atajar amenazas, así como comparar la escasa información proveniente de Guadalajara y Oaxaca con la existente en el centro del país.

En el caso de Guadalajara, las actas de cabildo civil cuentan con dos volúmenes impresos, que abarcan de 1607 a 1635 en el caso del primer volumen y de 1636 a 1668 en el segundo (Ayuntamiento Constitucional de Guadalajara-Instituto Jalisciense de Antropología e Historia-Instituto Nacional de Antropología e Historia, 1970). A partir de 1668 la información se encuentra en discos compactos que proporcionó el Archivo Histórico del Ayuntamiento de Guadalajara (AHAG), siendo los registros de actas de cabildo bastante esporádicos hasta 1771 . A partir de este último año y hasta 1865, año en que se suspendió la consulta, se regularizó el registro de actas, siendo la consulta en documentos originales a partir de 1822. En cuanto al cabildo eclesiástico de Guadalajara (ACCG), sus sucintas actas iniciaron su registro en 1552, y la consulta se prolongó hasta 1874 . Desafortunadamente, en ambos acervos el registro de ceremonias de rogativa fue mínimo. Por su parte, los archivos históricos del municipio de Oaxaca (AHMO) y de la arquidiócesis de Antequera-Oaxaca (AHAO), con inicio de registros de actas de cabildo en 1564 y 1640, respectivamente, se consultaron hasta 1872 y 1877, siendo asimismo muy escasos los documentos referentes a ceremonias de rogativa.

Guadalajara es conocida a la fecha por sus terribles tempestades eléctricas; urbes con condiciones materiales endebles eran mucho más vulnerables ante las descargas eléctricas. La Guadalajara de fines del siglo XVI sólo tenía cincuenta años de haberse fundado en el valle de Atemajac, por lo que sus edificaciones eran 
en su mayoría bastante humildes, victimas no sólo de las inclemencias del tiempo sino también de innumerables invertebrados: “... somos afligidos con justísima ira de Nuestro Señor Dios con muchos nuevos relámpagos y rayos, que han muerto muchas personas y con otras plagas venenosas de alacranes y otras sabandijas, temblores de tierra, peste... y acordaron para aplacar la indignación e ira... tomar principalmente por intercesora a la Virgen Santa María y que invocada la gracia del Espíritu Santo se echen suertes de todos los santos del calendario y el santo que saliere por suerte entre todos... cada año se le haga solemne fiesta en su día con vísperas y misas cantadas y procesión alrededor de esta Santa Iglesia, avisando para ello a los vecinos y moradores de esta ciudad... y salió en la suerte el bien aventurado San Clemente, papa y mártir, que el día de su festividad fue a 23 de noviembre..." (AHAG, Libro III; 1583-1598, 18-VIII-1592 y 24-VIII-1592).

Los extremos en variabilidad climática, que asolaron a la capital novohispana a principios del siglo XVII, parecen haberse manifestado también en Guadalajara. Gracias a las actas de cabildo del ayuntamiento de esta ciudad sabemos que entre 1606 y 1612 (AHAG, Libro 1; 1607-1635, 19-VII-1610, 8-X-1611 y 28-I-1612) fue constante la carestía de bastimentos, años en que la Ciudad de México estuvo primeramente bajo el agua (ACCM, extractos citados, 1607 y 1608), para después sufrir el rigor de la falta de lluvias en 1609 y 1612 (ACCM, extractos citados).

Para mediados del siglo XVII, la problemática de índole climática que más atormentaba a los habitantes de Guadalajara seguía siendo el azote de las tormentas eléctricas:

... por cuanto en esta ciudad han sucedido de algunos ańos a esta parte muchas desgracias de muertes de rayos, que Dios Nuestro Señor ha sido servido de enviar, por la poca devoción que se tiene al glorioso San Clemente, y que esta ciudad por su parte ayude para celebrar sus fiestas... y para este efecto acordaron que para este mes de mayo que entra, por principio de aguas, en el día que pareciere más a propósito se haga fiesta al glorioso santo en la iglesia Catedral... que habiendo conocido con ciencia experimental cuan agravada y trabajosa se hallaba esta ciudad con las continuas tempestades y rayos, cuyos efectos manifiestamente se vieron en esta ciudad en casos desastrosos... y porque es justo que en señal de agradecimiento y debidos obsequios a lo que el año pasado se vio patentemente y como obra sobrenatural, cesando las tempestades y rayos, siendo así que continuamente los ańos pasados sucedieron tantas y diferentes desgracias... y porque, asimismo, está ciudad tiene por devoto y abogado al glorioso pontífice San Clemente, por los rayos y tempestades que de continuo hay en ella, y cada ańo por entrada de aguas se le hace fiesta... la fiesta del glorioso 
y bienaventurado San Clemente, pontífice, patrón de esta ciudad, abogado de las tempestades de ella, está de próximo, y se acostumbra para el día del glorioso santo dar y librar este cabildo 12 pesos para la cera que se gastaba en los altares del convento de Santo Domingo, donde está la reliquia, y la fiesta principal que la ciudad hacia era por entrada de aguas, y porque ahora se ha acordado que toda la fiesta se haga el mismo día del santo y se prosiga novenario... (ACCG, Libro II; 1636-1668, 30-IV-1639, 12-I-1641, 20-V-1644 y 15-XI-1646).

La primera ocasión en que Guadalajara dio la alarma por escasez de lluvias y falta de granos fue en 1650 (ACCG, Libro II; 1636-1668, 1-VII-1650 y 14-XI-1650), siendo que el final de la década de 1640 se vivió con normalidad en el centro de México, y que la única anomalía reportada por aquellos años fue la abundancia de lluvias en Morelia y Puebla (ACMM y AHMP, extractos citados, 1652). La ausencia de precipitaciones en la Nueva España, y normalidad o abundancia en Nueva Galicia y viceversa, se documenta con precisión más adelante en este capítulo. El año de 1656 no manifestó anomalía alguna en el centro de México, mientras que Guadalajara se vio obligada a principios de mayo a organizar una rogativa de nivel IV contra la peste (ACCG, Libro II; 1636-1668, 8-V-1656), una primavera muy seca y caliente pudo influir en el desarrollo y expansión de esta epidemia.

El primer dato de índole climática que nos brindan las actas de cabildo del ayuntamiento de Oaxaca da cuenta de un profundo y lluvioso frente frío (AHAO, Libro 2; 1673-1693, 12-I-1677), ocurrencia de frentes fríos que, incluso en Puebla, fueron catastróficos a lo largo de la primavera de 1677 (AHMP, extracto citado). Sin ningún otro reporte de anomalía climática hasta la década de 1690 en Oaxaca, el cabildo eclesiástico dio cuenta en 1698 sobre la forma en que esta parte del país no se vio afectada por la extrema humedad que en el altiplano meridional de México se llegó a conocer como el año de chahuixtle (1691), y como ya se dijo, tantos estragos causó, agregándose en este extracto (AHAO, Libro 3; 1693-1708, 5-VI-1698), que: “... esta ciudad logró los alivios en las abundantísimas cosechas de maíz...”. Asimismo, se denuncia la falta de lluvias a principios de junio de 1698, solicitándose una rogativa pro pluvia de nivel V. En contraposición, sólo Puebla en el centro de México, reportó algún tipo de anomalía, siendo esta la abundancia de precipitación durante esa misma primavera (AHMP, extracto citado, 1698). Tres años después se dio cuenta de rogativas en Oaxaca (AHAO, Libro 3; 1693-1708, 30-IV-1701), sin que se especifique el motivo. Posiblemente este ceremonial fue causado por una primavera muy seca, ya que un mes después 
la capital del virreinato se vio en la necesidad de conducir ceremonia pro pluvia de nivel V (AACM, extracto citado, 1701).

La década de 1710 dejó huella por sus inclemencias meteorológicas, tanto en Guadalajara como en Oaxaca. La capital de Nueva Galicia informó en octubre de 1713 sobre lo calamitoso de los tiempos, habiendo sido tan acusada y fuera de lo común la falta de lluvias que se restableció el patronazgo de san Martín para atajar los malos temporales y plagas, así como para solicitar buenas cosechas (AHAG, Libro VIII; 1707-1720, 24-X-1713). La acritud de este evento es evidente, a su vez, en tanto que al comenzar el verano de 1714 se llevaron a cabo rogativas de nivel IV para que las lluvias se mantuvieran (ACCG, Libro 4; 1708-1716, 27-VI1714). Tres ańos después tuvo lugar en Oaxaca una rogativa pro pluvia de nivel V (AHAO, Libro 4; 1709-1736, 7-VI-1717). Lo acontecido en Guadalajara durante estos años tuvo paralelo en 1713 en la Ciudad de México, donde en mayo y junio fue necesario recurrir a rogativas pro pluvia de nivel IV y V (AACM, extracto citado, 1713). A su vez, el evento registrado en Oaxaca también lo sufrió simultáneamente la capital virreinal, en donde también se hizo indispensable un ceremonial pro pluvia a principios de junio de 1717 (ACCM, extracto citado, 1717).

Durante la década de 1720, únicamente Guadalajara reportó en 1728 algún tipo de anomalía, la cual produjo escasez de granos, tanto en dicha capital como en Sayula (AHAG, Libro IX; 1720-1732, 11-VI-1728), situación que no fue sufrida en el centro de México. En contraposición, la década de 1730 fue bastante inestable en términos ambientales en Oaxaca, ciudad que manifestó en 1730 tanto epidemia como mortandad de ganados (AHMO, Libro 2; 1728-1733, 3-III1730 y 6-III-1730), lo que hizo ineludible la conducción de rogativas de nivel V. $\mathrm{Al}$ año siguiente (1731) la antigua Antequera manifestó una urgente necesidad de lluvias (AHMO, Libro 2; 1728-1733, 15-VII-1731 y 16-VII-1731), por tanto su ayuntamiento exhortó a la realización de rogativas pro pluvia de nivel IV. Dos años después (1733), Oaxaca volvió a ser asolada por la escasez de lluvias (AHMO, Libro 2; 1728-1733, 20-VI-1733, 2-X-1733 y 26-X-1733), y para principios de octubre se patentizó un ceremonial pro pluvia de nivel IV. Las penas en Oaxaca no cejaron, habiéndose sufrido un terrible capítulo de epidemia entre 1737 y 1738 (AHAO, Libro 5; 1736-1753, 16-II-1737, 8-XI-1737, 1-II-1738, 16-III-1738, 17-VI1738 y 6-VIII-1738), el cual busco ser atajado por medio de rogativas de nivel V en febrero de 1737, noviembre de ese mismo año, así como, febrero, marzo, junio y agosto de 1738 .

A diferencia del occidente y sur de México, la década de 1720 fue desde su inicio bastante cruenta a causa de la escasez de lluvias en los altiplanos central y meridional (AACM, extracto citado, 1720 y ACCM, extracto citado, 1720). Asimis- 
mo, los años de 1723, 1725 y 1726 manifestaron escasez de precipitaciones (AACM, extracto citados, 1723 y 1726, y AHMP, extracto citado, 1725). Lo calamitoso de la década de 1730 fue patente tanto en el centro como en el sur de México (véase párrafo anterior); siendo 1730, 1733 y 1737, los años en que ambas áreas manifestaron inclemencias ambientales (ACMM, extracto citado, 1730; AACM y AHMP, extractos citados, 1733, y ACCM y AHMP, extractos citados, 1737). Lo terrible que resultó el ańo de 1739 (ver capítulo anterior) para las capitales del centro-sur de México no dejó huella ni en Guadalajara ni en Oaxaca. Por su parte, Guadalajara sólo dejó noticia durante la década de 1730 de un capítulo epidémico ocurrido durante el otońo de 1734 (AHAG, Libro X; 1732-1746, 5-X-1734).

A lo largo de la década de 1740 se asentaron en Oaxaca tres extractos que reportaron falta de lluvias y escasez de bastimentos en 1741, 1746 y 1747, aunque sólo el de 1741 hace referencia a una rogativa pro pluvia, esta de nivel IV, solicitada el 20 de junio de dicho año (AHAO, Libro 5; 1736-1753, 9-X-1746, 4-XI-1746 y 29-VII-1747). La década siguiente, la de 1750, sólo en Guadalajara se encontró un documento que tratase sobre las inclemencias del tiempo, fechado el 10 de abril de 1756, y que denunciaba a la letra “... los malos tiempos que han padecido delicadeces de cosechas y mortandad de ganados, con lo que han minorado los diezmos y aumentado los precios de los mantenimientos..." (AHAG, Libro XI; 1746-1759, 10-IV-1756).

La década de 1760, que fue marcadamente inclemente en el centro-sur de México (véase el capítulo anterior), solo dejo huella en Guadalajara y Oaxaca de capítulos epidémicos que se verificaron en 1762, 1763 y 1768, en la primera ciudad, y en 1769 en la segunda (ACCG Libro s/n; 1762-1763, 3-III-1762, 15-VII1763, 9-IX-1763; AHAG, Libro XII; 1759-1781, 21-X-1768 y AHAO, Libro 6; 17531770, 17-III-1769). A pesar de las inconsistencias en los registros de Guadalajara, se puede constatar que mientras 1762 fue un año seco en la capital de la Nueva España (ACCM, extracto citado, 1762), en la futura capital de Jalisco se tuvo un buen temporal de lluvias: “... el beneficio que se ha experimentado en el presente tiempo de aguas, se prometen abundancia de cosechas..." (ACCG, Libro s/n; 1762-1763, 15-X-1762). Un occidente de México más húmedo entre 1760 y 1795 parece ser común, tal y como manifiestan el último extracto citado, así como varios de los siguientes. Tenor que guarda este fechado en 29 de julio de 1771 (ACCG, Libro 6; 1771):

... Dijo que hasta la presente no se puede conjeturar, con algún mediano acierto la escasez que se teme de maíces, respecto a que el temporal que se está experimentando, no está rigorosamente contrario, ni se puede temer limitación en las 
cosechas de esta semilla, que sólo si, se puede temer falla o escasez, en atención a que como generalmente, se dice haber entrado las aguas, en la Nueva España, con una limitación notable de que resultara indubitable, el que, de aquel reino entren a comprar a este, y de éste ir a vender a aquel, que en este caso no hay duda se escaseará en estas tierras dicha semilla, aunque sean las cosechas correspondientes y añade que si en lo de adelante se escasean las lluvias es consecuente la pérdida de las milpas...

Por su parte, el obispado de Oaxaca realizó rogativas (AHAO, Libro 7; 17701792, 11-VI-1771), sin que se especifique el motivo, cuatro días antes que la capital virreinal hiciese lo mismo y por segunda vez a causa de la terrible seca que se experimentaba (ACCM, extracto citado, 1771). Lo que invita a pensar que la ciudad suriana también se encontraba bajo el flagelo de la extrema escasez de lluvias. El año de 1773 también dejó huella de la abundancia y buenos tiempos de la Nueva Galicia contra la miseria y escasa precipitación de la Nueva España (ACCG, Libro 1; 1773, 21-VII-1773 y 22-X-1773):

... con el motivo de la copiosa avenida de agua que inundó y maltrató gravemente el puente de San Juan de Dios... habiendo experimentándose en el reino de la Nueva España general escasez de maíces en el año próximo pasado para su surtimiento y abasto en el presente, es preciso es indispensable, que ella continúe con mayor extremo para el próximo venidero a causa de la helada que acaeció por el mes de mayo y que destruyó enteramente todo lo que hasta entonces se había sembrado, que es la mayor parte de aquel reino por la ordinaria anticipación de las aguas, en Nueva Galicia, no disfrute este público la utilidad y beneficio que le prepara la abundancia de cosechas que se promete (por las cantidades de maíz que se podrían llevar a la Nueva Espańa)...

Este marcado contraste entre buenos y malos temporales entre el centro (extractos citados, ACCM, AACM y AHMM, 1774) y el occidente de México (ACCG, Libro 8; 1774, 29-X-1774) también se manifestó en 1774, y asimismo, Oaxaca volvió a reportar ceremoniales de rogativa sin especificar el motivo (AHAO, Libro 7; 1770-1792, 20-IX-1774). Con respecto al año de 1775, no se encontró registro alguno ni en Guadalajara ni en Oaxaca, que tratase cuestiones ambientales y los reportes concernientes a 1776 hablan de buenos tiempos e incluso de fuertes precipitaciones, en el caso de la primera ciudad (ACCG, Libro 10; 1776, 3-VII-1776, 4-VII-1776 y 22-VIII-1776 y AHAO, Libro 7; 1770-1792, 4-V-1776). En contraposición, las ciudades de México y Puebla manifestaron fuertes estiajes en 1775 y 
1776 (AACCM, ACCM y AHMP, extractos citados, 1775 y 1776). Las postrimerías de la década de 1770 sólo dejaron en Guadalajara y Oaxaca reportes de epidemia en 1778, así como la entrada temprana de las lluvias, en el caso de la primera ciudad (ACCG, Libro 14; 1778, 29-I-1778 y 6-IV-1778) y también de epidemia en el caso de la segunda, pero al año siguiente (AHAO, Libro 7; 1770-1792, 30-XII1779). La tendencia observada a lo largo de las dos últimas dos décadas se cumplió a principios del verano de 1778 , la capital del virreinato cuenta con rogativas pro pluvia hacia el 8 de junio (ACCM, extracto citado,1778), penurias a las que se sumó Puebla al año siguiente (AACM y AHMP, extractos citados, 1779).

Los años de 1780 y 1781 fueron abundantes en precipitación en Guadalajara, siendo el primero abundante en cosechas (ACCG, Libro 33; 1780, 3-XI-1780 y 27-IX-1781); sin embargo, los excesos hídricos provocaron que los campos se anegaran en el verano de 1781 y el acopio de granos fue escaso hacia el otońo de dicho año (ACCG, Libro 41; 1781, 14-XI-1781). Por su parte, la antigua Antequera reportó una rogativa de nivel $\mathrm{V}$ en junio de 1780 , sin que se especificara el motivo (AHAO, Libro 7; 1770-1792, 10-VI-1780) y para agosto de 1781 constataba la presencia de estiaje, epidemias y "escasez de bastimentos" (AHAO, Libro 7; 17701792, 20-VIII-1781). Estos extractos son los últimos que guardan cierta continuidad en Oaxaca; a partir de este año las referencias halladas en los acervos, tanto de la catedral como del ayuntamiento, son aún más escasas.

Los acervos de Guadalajara no tienen ningún recuento de índole climática o con posible injerencia de extremos en variabilidad climática, entre el otońo de 1781 y el invierno y la primavera de 1785 , cuando se dio cuenta de una terrible epidemia, que entre enero y abril provocó la realización de cuatro ceremoniales de rogativa, dos en sus niveles III, uno de nivel IV y uno de nivel V (AHAG, Libro XIII; 1781-1788, 25-I-1785 y ACCG, Libro 5; 1785, 23-III-1785, 29-III-1785 y 16IV-1785). Por su parte, en el centro de México, durante estos primeros cinco años de la década de 1780, sólo se reportaron rogativas pro pluvia de nivel V durante la primavera de 1780 en México y Puebla (ACCM y AHMP, extractos citados, 1780) y el verano de 1784 en Morelia (ACMM, extracto citado, 1784). Al conjuntarse los datos del centro y occidente, parece perfilarse que fuertes capítulos epidémicos fueron el primer efecto de las ya mencionadas fases eruptivas del volcán Laki entre 1783 y 1785 (ACCM y AACM, extractos citados, 1784 y ACMM, extractos citados, 1785).

Respecto a los terribles eventos de 1785, al unísono que el centro de México, Guadalajara dio la alarma el 27 de septiembre de dicho año, en los siguientes términos (ACCG, Libro 5; 1785): 
... y con presencia de que en estos días inmediatos se han experimentado una extraordinaria mudanza del temporal, escaseando el agua y amenazando de suerte que aún se temen heladas...

La pérdida de las cosechas, a principios del otoño de 1785, dejó en Guadalajara varios documentos (AHAG, Libro XIII; 1781-1788, 8-III-1786 y ACCG, Libro 8; 1786, 17-I-1786, 14-II-1786 y 1-III-1786), terrible carestía a la que siguió una fuerte epidemia hacia la primavera siguiente (22-IV-1786). Afortunadamente, los sufrimientos aquí referidos tuvieron cierto alivio gracias a que la cosecha de trigo del verano de 1786 fue buena (13-XII-1786). Después de este último extracto, pasaron tres años sin que Guadalajara reportara alguna situación grave de origen climático o vinculada a extremos en variabilidad climática. La escasez, con buenas o malas cosechas, perduró en Guadalajara hasta fines de 1788 (AHAG, Libro XIV; 1788-1794, 2-XII-1788). Al año siguiente (1789) se dio cuenta de una epidemia hacia la primavera (ACCG, Libro 10; 1789-1790, 11-V-1789), así como de escasez de granos el otońo siguiente (ACCG, Libro 11; 1789, 9-X-1789 y 28-X1789). Un ańo de 1786 menos severo hacia el occidente de la Nueva España y la Nueva Galicia da continuidad al patrón observado a lo largo del último cuarto de siglo, el cual se vio abruptamente interrumpido ante los eventos extremos de 1785-1786. Tendencia que parece invertirse en 1789, año en el que Guadalajara y Morelia reportaron, respectivamente, falta de granos y una fuerte canícula (ACMM, extractos citados, 1789).

La década de 1790 comenzó con un buen verano en términos de cosechas para Guadalajara (ACCG, Libro 10; 1789-1790, 31-VIII-1790), y al parecer la bonanza se mantuvo hasta 1793 (ACCG, Libro 4; 1793, 1-VI-1793). Felicidad que se vio dramáticamente interrumpida a principios del verano de 1794 al manifestarse una pronunciada escasez de lluvias, la cual dio lugar a rogativas pro pluvia de nivel $\mathrm{V}$, siendo este uno de los pocos extractos que en ambos acervos de Guadalajara da cuenta del procedimiento y pompa de este tipo de rogaciones públicas (ACCG, Libro 6; 1794, 7-VII-1794 y 14-VII-1794):

... que respecto a lo calamitoso que parece se va poniendo el año, y que el único remedio es ocurrir al auxilio Divino y que por tanto juzgar ser oportuno, celebrar una misa cantada solemne, con general rogación en las demás iglesias, y que como se dé en beneficio del público, a quien pertenecen los caudales de propios, se sirva su excelencia dar la licencia necesaria para que del mismo se eroguen los costos necesarios; para que conseguida se concordará este cuerpo con el Señor Gobernador de este Obispado en el día en que ha de celebrarse. 
Se convide a los tribunales y religiones a fin que estando el Divinísimo Sacramentado presente hagan los tribunales y pueblo sus clamores, a imitación de lo que en iguales circunstancias se ha ejecutado en otras ocasiones... Se dio cuenta con el oficio del M.Y.S.P. concediendo la licencia para la misa de rogación al Divinísimo Sacramento por el agua, siempre que esta falte y no variando el temporal como parece, se acordó que respecto ha haber variado el temporal y que en el Santuario de Nuestra Señora de Guadalupe a solicitud de un cura, se está cantando novenario a la Santísima Señora por el mismo fin, se impetre venia del Superior Gobierno para asistir este cuerpo al último día de rogación pública por medio de diputación...

Afortunadamente para la capital de la Nueva Galicia, el tiempo parece haber mejorado después de mediados de julio, lo que permitió una tardía pero favorable cosecha (ACCG, Libro 5; 1794, 6-XI-1794). El siguiente año, 1795, dio cuenta de una vigorosa entrada de la estación de lluvias hacia el 25 de junio, sin que esto impidiera que para el día 30 se organizara un ceremonial que implorase para que "las presentes aguas sean fértiles" (ACCG, Libro 4; 1794-1797). A diferencia de Guadalajara, en el centro del país se reportó falta de lluvias en 1790 y 1793 (AACM, extractos citados, 1790 y 1793; ACMM, AHMM y AHMP, extractos citados, 1793). La extrema escasez de precipitaciones fue común al centro y occidente de México en 1794 (ACCM, AHMM y ACMM, extractos citados, 1794), situación que se prolongó en la capital del virreinato y Morelia hasta la primavera de 1795, y en estas dos ciudades, como en Guadalajara, se dio cuenta de la entrada de las lluvias entre la segunda y la tercera semana de junio (AACM, ACMM y AHMM, extractos citados, 1795). Aunque con menor recurrencia, continúa la tendencia de un occidente más húmedo con respecto al centro del país.

El año de 1796 fue benévolo tanto para el centro como para el occidente de México, y en 1797 únicamente la antigua Valladolid dio la alarma por escasez de lluvias (AHMM, extractos citados, 1797). Un extracto aislado, proveniente del archivo eclesiástico de Oaxaca (AHAO, Libro 8; 1792-1807, 13-II-1797), constata la magnitud, en términos territoriales y de virulencia de la epidemia que también causó estragos ese año en México y Puebla (ACCM y AHMP, extractos citados, 1797). 1798 fue un año que dejó rogativas pro pluvia de nivel V en México y Puebla, y una de nivel IV en Morelia (ACCM, ACMM y AHMP, extractos citados, 1798), la menor pompa del ceremonial, como la ausencia de reportes que hablen de faltas de lluvias en Guadalajara, permiten presumir que de nuevo se asiste al patrón que ha predominado desde 1760, y que manifiesta mayor humedad al oeste del meridiano 102. El año de 1799 fue funesto para México, Morelia 
y Puebla (ACCM, ACMM, AHMM y AHMP, extractos citados, 1799), y al parecer Guadalajara (ACCG, Libro 16; 1799, 10-VI-1799) también sufrió la escasez de lluvias, ya que cuenta con el registro de un ceremonial que, por sus características y coincidencia temporal con rogativas pro pluvia asentadas en las tres primeras ciudades, permiten inferir que al occidente del país también se sufrió un invierno y primavera secos.

Los dos primeros años del siglo XIX dejaron constancia de escasez de lluvias en Guadalajara (ACCG, Libro 2; 1800, 21-VII-1800 y AHAG, Libro XV; 1794-1809, 31-X-1801), ambos años calificados como extremamente secos en los registros de las ciudades de México y Morelia, y el de 1801 en la capital poblana (AACM, ACCM, AHMM y AHMP, extractos citados, 1800 y 1801). El año de 1802 fue calamitoso en la capital de la Nueva España (AACM y ACCM, extractos citados, 1802), por lo que se tuvieron que llevar a cabo rogativas pro pluvia de nivel $\mathrm{V}$ a principios de mayo, fechas por las que la antigua Antequera también condujo rogativas (AHAO, Libro 8; 1792-1807, 10-V-1802) y aunque no se especifica el motivo, se propone a partir de la simultaneidad de las ceremonias que los valles centrales de Oaxaca y la cuenca de México compartían los mismos rigores. En Oaxaca, más tarde esa misma primavera, se emprendieron acciones políticoreligiosas para enfrentar la plaga de langostas (AHAO, Libro 8; 1792-1807, 30-V1804 y 15 -VI-1804).

La interrupción en los registros, después de una relativa continuidad a lo largo del siglo XVIII, también tuvo lugar en Guadalajara a partir de 1805. Los últimos extractos registrados y tocantes a cuestiones climáticas tienen fecha de 19 de agosto y 9 de septiembre de 1805 (ACCG, Libro 12-I; 1805), dándose cuenta en ellos de una extraordinaria riada ocurrida el 4 de agosto de ese año, así como de la continuación de las lluvias a lo largo del siguiente mes. Por su parte, las ciudades de México y Morelia condujeron dos meses antes ceremoniales pro pluvia de nivel V (AACM y ACMM, extractos citados, 1805).

Entre los escasos datos provenientes de Guadalajara después de la primera década del siglo XIX, se tiene que el año de 1819 fue reportado como bueno, en términos de la abundancia de lluvias y cosechas en Guadalajara (ACCG, Libro 15; 1819, 8-XI-1819), así como un otoño severo en 1820, lo que provocó una epidemia de "fiebres catarrales" (ACCG, Libro 17; junio a diciembre de 1820, 27-XI-1820). Una epidemia mortal dio lugar a la generación de seis extractos por parte del cabildo civil de Guadalajara en 1823 (ACCG, Libro 182; enero a agosto de 1823 y Libro 183; septiembre a diciembre de 1823, 12-VII-1823, 7-VIII-1823, 18-VIII1823, 4-X-1823, 18-XII-1823 y 22-XII-1823), mortandad concentrada en el pueblo de Ocotán (en el actual municipio de Zapopan). La primavera siguiente, al 
parecer, dio signos de escasez de lluvias y para el 31 de mayo se pide que se traiga a la virgen de Zapopan (ACCG, Libro 184; enero a junio de 1824, 31-V-1824): “... a esta capital lo más pronto posible, para impetrar a su majestad su poderoso auxilio y protección en las presentes circunstancias..."; el motivo de tal solicitud no quedó aclarado, pero el lenguaje utilizado, la época del año en que se piden las rogativas y el que no se trata del ceremonial anual preestablecido, permiten presumir que su finalidad era para pedir por las lluvias, las cuales se manifestaron con fuerza hacia la primera quincena de julio (ACCG, Libro 185; junio a diciembre de 1824, 9-VII-1824). Misma quincena que en Oaxaca se reportaba bajo los efectos de la canícula, de cuya intensidad y duración, se asentó, dependería la fijación de los precios para el maíz (AHMO, Actas de Sesiones, Libro 6, 1824, 19-VII-1824).

En cuanto al México central, durante el período descrito en el párrafo anterior, se tiene que a diferencia de Guadalajara, el invierno y la primavera de 1819 fueron bastante secos (ACCM, extractos citados, 1819), sin que tampoco exista paralelo con los eventos epidémicos ocurridos en 1820 y 1823, y solo Puebla (AHMP, extracto citado, 1824) manifestó algún evento climático extremo durante 1824, padeciendo al igual que Oaxaca una fuerte canícula durante el verano de ese año.

Del segundo cuarto del siglo XIX, en Oaxaca, solo se encontraron registros tocantes a cuestiones ambientales procedentes de los años de 1829 y 1839 , mientras que los originados en Guadalajara, durante este mismo período, suman nueve. Del ańo de 1829 proceden ocho extractos del cabildo civil de Oaxaca, mismos que dieron cuenta de una fuerte epidemia, tanto en los valles centrales de Oaxaca como en el istmo de Tehuantepec (AHMO, Actas de sesiones, Libro 8, 1829, 26II-1829, 9-III-1829, 16-III-1829, 21-III-1829, 24-III-1829, 30-III-1829, 14-V-1829 y 13-VII-1829). Episodio epidémico que se manifestó en Jalisco al siguiente año (ACCG, Libro 195; mayo a octubre de 1830, 10-IX-1830). El episodio epidémico de 1839 en la ciudad de Oaxaca dejó constancia por medio de un solo extracto (AHMO, Tesorería municipal, tomo IV; 1839-1850, 13-III-1839).

Los nueve documentos procedentes de Guadalajara para este período son en lo primordial referentes a capítulos epidémicos ocurridos en 1836, 1837, 1840, 1843 y $1844 ;^{1}$ sin embargo, de estos años proviene uno de los escasos documentos que detalla en Guadalajara la oficialización de un ceremonial pro pluvia, el

1 (ACCG, Libro 209; junio a diciembre de 1836 y enero a abril de 1837, 21-X-1836; AHAG, Libro XIX; 1834-1842, 7-IV-1837; ACCG, Libro 210; abril a diciembre de 1837, 8-IV-1837 y 26V-1837; AHAG, Libro de Pelicanos núm. I; 1773-1880, 24-XII-1840; ACCG, Libro 217; enero a diciembre de 1843, 9-II-1843 y ACCG, Libro 218; enero a diciembre de 1844, 3-V-1844). 
cual tuvo una categoría de nivel IV y se registró el 12 de agosto de 1840 (AHAG, Libro de Pelicanos, núm. I; 1773-1880):

... acordaron que se implore la misericordia de Dios en la actual escasez de aguas, sino llueve en el día de hoy, encargando al señor cura de Mexicalzingo que con la mayor solemnidad que pueda, conduzca al Señor Crucificado de aquella parroquia el día de mañana en la tarde a la iglesia de San Francisco, adonde concurrirá el cabildo a conducirlo a esta Santa Iglesia y que el domingo comience un triduo de misas cantadas delante de su majestad, pidiéndole el socorro de las lluvias...

El año de 1840 manifestó fuertes capítulos epidémicos en Morelia y Puebla (ACMM y AHMP, extractos citados, 1840) y una pronunciada falta de precipitación en las tres ciudades tratadas en el centro del país en 1841 (AACM, ACCM, ACMM y AHMP, extractos citados, 1841). Severidad atmosférica que también tuvo lugar en Guadalajara, de acuerdo con el siguiente documento fechado en 27 de enero de 1842 (ACCG, Libro 216; enero a diciembre de 1842):

A moción de la comisión de fuentes, se acordó ponerse en estado de servicio la noria que se haya en la casa conocida por ser de don Domingo Altamirano para auxiliar con ella las fuentes. En virtud, de que ya ha servido a este objeto... de la escasez que ahora está sufriéndose por lo tímido que fue el pasado temporal de aguas...

La fuerza de las tormentas y estragos causados por las descargas eléctricas es una característica de la capital de Jalisco que, como ya se dijo, ha sorprendido a sus habitantes desde mediados del siglo XVI hasta nuestros días. En los acervos consultados en Guadalajara se dio cuenta de ello a lo largo de los registros y su vigencia a mediados del siglo XIX queda constatada en los dos siguientes extractos correspondientes a los años de 1836 y 1864 (AHAG; Libro XIX, 1834-1842, 1-IX1836 y ACCG; Libro 236, 22-XI-1864):

... las desgracias que en esta Santa Iglesia han causado los rayos en el presente año y reflexionando que el glorioso San Clemente patrono de esta ciudad no tiene altar propio, acordaron que se coloque su imagen en el de Santa Rosa... con el objeto de reestablecer el solemne triduo que se hacía antes de ahora a dicho santo... (participación del cabildo eclesiástico, tribunal de justicia y ayun- 
tamiento)...” y “... Triduo a San Clemente, patrón contra los rayos; obligación del ayuntamiento de asistir...

De la segunda mitad del siglo XIX, solo se consultaron en los archivos civil y eclesiástico de Guadalajara los años comprendidos entre 1850 y 1865. Período del que se tiene que 1850 fue un ańo seco y escaso de semillas (AHAG, Libro de Pelicanos núm.1; 1773-1880, 5-X-1850), y que durante el primer semestre de 1857 tuvo lugar una fuerte epidemia de viruelas en diversas poblaciones del estado de Jalisco (ACCG, Libro 230; enero a diciembre de 1857, 6-III-1857, 13-V-1857 y 23-VII-1857).

Cabe señalarse que en las ciudades de Oaxaca, San Cristóbal de las Casas, Mérida, Durango y Hermosillo, donde la obtención de datos por medio de la consulta de las actas de cabildo civil y religioso fue bastante limitada, se echó mano de fuentes bibliográficas que pudiesen brindar datos climáticos anteriores al inicio de los registros meteorológicos sistematizados e institucionalizados. En el caso de Oaxaca, se encontró la obra de Jorge Fernando Iturribarria (1982), texto que nos brinda cuatro interesantes datos de índole climática entre 1824 y 1853 en su primer tomo:

1. "Una fuerte tormenta con granizo ocurrida el 8 de febrero de 1824 y que duró varias horas, fenómeno inusual en el sur del país en esta época del año, que pudo ser consecuencia de un profundo y fuerte frente frío" (Iturribarria, 1982: 35-37). Asimismo, cabe recordar que en 1824 tuvo lugar una fuerte canícula, tanto en Puebla, como en Oaxaca. Esto aunado a la extrema sequedad de 1825, nos permite inferir lo anómalo que fue el bienio 1824-1825 en el centro y sur de México (AACM, ACMM, AHMM y AHMP, extractos citados, 1825).

2. “Así pasó 1836, y así llegó el siguiente año (1837). Se inició con un calor insoportable que fundía la cera de las iglesias, y que unos atribuían a buen año de lluvias, y otros señalaban como signo inequívoco de que la sequía era el fatal horóscopo... Se hicieron muchas rogativas, triduos y novenarios en los templos de la ciudad, implorando el favor del cielo para que ese año lloviera... 1839... el cielo se mostraba despejado de nubes y, cargado de una atmósfera caliginosa... llegaron los primeros días de mayo y pasaron los últimos... Se envía a Oaxaca una talla de la Virgen de los Remedios, patrona de las lluvias en la Ciudad de México... La imagen quedó depositada en la iglesia Catedral y allí se celebró una solemne función religiosa con misa cantada. Al día siguiente dio principio 
un novenario con procesiones que recorrían las calles de la ciudad... no obstante las ardientes rogativas a la divinidad, por intercesión de la patrona de las lluvias, las nubes no dejaron caer su codiciado tesoro sobre las tierras áridas..." (Iturribarria, 1982: 242). Ese mismo año, tanto Morelia, como Puebla se vieron en la necesidad de conducir ceremoniales pro pluvia a fines de la primavera (AHMM y AHMP, extractos citados, 1837).

3. “... 24 de septiembre de $1844 \ldots$ la abundancia de lluvias ocasionó que los ríos de Tehuantepec se salieran de madre, inundando la cabecera del partido... Juquila y Juchatengo habían sufrido los efectos de una espantosa inundación con pérdidas de vidas... abarcando la inundación los pueblos de Huaxolotitlán, Chicometepec y Pinotepa...” (Iturribarria, 1982: 307). Esta información, parece detallar un ciclón que afectó a la totalidad del litoral oaxaqueño. Asimismo, como ya quedó manifiesto en el capítulo anterior, la década de 1840 se caracterizó por su benevolencia, después de cerca de ochenta años de una marcada recurrencia de eventos extremos secos; fin de la PEH que en parte puede ayudar a explicar eventos como el siguiente:

4. “... marzo de 1853... A fines de ese mismo mes, dos formidables mangas de langosta, una de 8 leguas de extensión y otra de 7, invadieron los bosques de las regiones sur y sureste del estado, devorando las siembras de los distritos de Tehuantepec, Choapan, Villa Alta, San Carlos Yautepec, Miahuatlán y Ejutla...." (Iturribarria, 1982: 434). Como ya se ha visto, la presencia de plagas de langosta en el México central es prácticamente inexiste hasta fines del siglo XVIII, azote que se hace más común conforme se aproxima uno a la América Central, ya por Chiapas y Tabasco, ya por la península de Yucatán. En este sentido, la hipótesis es que las condiciones más frías y secas de la $\mathrm{PEH}$ no produjeron la biomasa necesaria para la multiplicación geométrica de especies del género Locusta. 
Tabla 1. Tabla que muestra los contrastes climáticos entre el centro y el occidente de México durante la segunda mitad del siglo XVIII.

\begin{tabular}{|c|c|c|c|c|c|c|c|}
\hline \multirow{2}{*}{\multicolumn{2}{|c|}{$\begin{array}{c}\text { Guadalajara } \\
\text { (sin referencia de } \\
\text { secas a lo largo de la } \\
\text { década de 1760) } \\
\text { Años }\end{array}$}} & \multicolumn{2}{|c|}{ Morelia } & \multicolumn{2}{|c|}{ México } & \multicolumn{2}{|c|}{ Puebla } \\
\hline & & \multicolumn{2}{|c|}{ Años } & \multicolumn{2}{|c|}{ Años } & \multicolumn{2}{|c|}{ Años } \\
\hline Húmedos & Secos & Húmedos & Secos & Húmedos & Secos & Húmedos & Secos \\
\hline 1771 & 1781 & & 1761 & & 1761 & & 1761 \\
\hline 1773 & 1785 & & 1763 & & 1762 & & 1771 \\
\hline 1774 & 1786 & & 1766 & & 1767 & & 1772 \\
\hline 1780 & 1789 & & 1767 & & 1768 & & 1773 \\
\hline 1793 & 1799 & & 1770 & & 1770 & & 1775 \\
\hline 1794 & & & 1771 & & 1772 & & 1779 \\
\hline \multirow[t]{10}{*}{1795} & & & 1772 & & 1774 & & 1793 \\
\hline & & & 1774 & & 1775 & & 1798 \\
\hline & & & 1779 & & 1779 & & 1799 \\
\hline & & & 1780 & & 1785 & & \\
\hline & & & 1789 & & 1786 & & \\
\hline & & & 1793 & & 1793 & & \\
\hline & & & 1794 & & 1794 & & \\
\hline & & & 1795 & & 1795 & & \\
\hline & & & 1798 & & 1798 & & \\
\hline & & & 1799 & & 1799 & & \\
\hline
\end{tabular}





\section{Capítulo 4. Durango y Sonora}

Los datos obtenidos en el Archivo Histórico de la Arquidiócesis de Durango (se consultaron actas de cabildo entre 1621 y 1871) fueron los más valiosos fuera del México central en cuanto a la obtención de conocimiento climático por medio de la consulta de los registros institucionales de los ceremoniales de rogativa, en particular los conducidos para pedir por las lluvias. Gracias a esta información se logró una serie climática fiable cercana a los cien años. Aproximación a la evolución secular del clima en el noroeste de México, en la que, en primera instancia, se reconoce el carácter extra tropical y de marcada continentalidad de buena parte de los eventos que afectan a esta zona del país, lo cual hace que la percepción de seca se genere con mayor dilación que en el México central, y ya no se diga que en el meridional. El archivo municipal de Durango fue incendiado en el marco de la guerra de Reforma, por lo que sólo contiene algunos datos aislados anteriores a la consolidación del régimen liberal mexicano.

Por su parte, el itinerante archivo del obispado de Sonora, creado en 1779, tuvo como primera sede oficial a la pequeña ciudad de Arizpe, capital militar y política de Sonora por aquel entonces; sin embargo, el primer obispo prácticamente no residió en tan lejano sitio y cambio la sede obispal a Álamos, 400 kilómetros al suroeste y de más fácil acceso desde el actual estado de Sinaloa y el mar. Los dos primeros obispos fueron quienes residieron en Álamos, el tercero condujo su mandato desde Rosario, en el extremos sur de Sinaloa, y el cuarto trasladó la sede a Culiacán. La posible existencia de un archivo eclesiástico proveniente de este obispado, obligó a viajar tanto a la ciudad de Álamos como a Hermosillo, siendo el resultado negativo, quedando pendiente la consulta de los acervos depositados en Culiacán, pero lo tardío de este obispado y sus constantes traslados en su primera época, así como la subsecuente separación con sedes en Culiacán y Hermosillo, brindan pocas esperanzas de lograr un trabajo fructífero. Por su parte, los acervos civiles de Álamos y Hermosillo, no comienzan sus registros sino hasta 1874 y 1873 , respectivamente, por lo que son de poco interés para este trabajo. 


\section{Durango: comparación de sus datos con los del centro y occidente de México}

En la ciudad de Durango, el primer registro sobre algún tipo de vicisitud ambiental tiene fecha de 1 de junio de 1667 y es tocante a una epidemia (AHAD, Libro III; 1671-1681). El siguiente extracto con información similar quedó asentado hasta 1703, tratándose asimismo de un capítulo epidémico (AHAD, Libro IV; 1703-1720, 16-XI-1703), que fue enfrentado por medio de un ceremonial de nivel V. Situación que también se repitió y quedó asentada el 19 de abril de 1712 (AHAD, Libro IV; 1703-1720). De acuerdo con uno de los escasos aportes del archivo civil de Durango, el año de 1726 fue funesto por la gran cantidad de decesos ocurridos, lo que obligó a recurrir a la figura de Santa Bárbara como patrona menos principal por parte de ambos cabildos ante este tipo de urgencias (AHGD, Sala de Acuerdos; exp. 57, 1845).

El primer ceremonial pro pluvia, encontrado en las actas de cabildo de la catedral de Durango, tuvo lugar a partir del 22 de junio de 1742, sin que se hubiesen detallado los tipos de ceremoniales realizados (AHAD, Libro VI; 1739-1747); secas que por las mismas fechas se manifestaron en el México central (AACM y ACCM, extractos citados, 1742). Siete años después se manifestó una escasez de lluvias aún más acusada, por lo que con fecha de 2 de septiembre de 1749 quedó plasmada la realización de un ceremonial pro pluvia de nivel V (AHAD, Libro VII; 1748-1751):

... este cabildo se había convocado a fin de tratar de traer de su santuario a María Santísima Madre Señora de Guadalupe en procesión a esta Santa Iglesia, en la que se hiciera un novenario, atendiendo a la urgente necesidad de el agua, con cuya protección, podía esperarse intercediese con su Santísimo Hijo, el remedio que tanto se necesita... que la Santísima Señora baje el miércoles en la tarde y que desde el jueves empiece el novenario; que se pongan seis velas de a libra y los cirios, cómo en función de primera clase... el señor Dean pase aviso a las religiones para la asistencia y toque de rogativa...

Tomando en cuenta los extractos anteriores, se propone a la década de 1740 como el inicio de la serie climática de Durango. La cual tiene en el año de 1758 el siguiente ceremonial pro pluvia asentado, esta vez de categoría IV (AHAD, Libro VIII; 1751-1759, 21-VI-1758). Al parecer, la extrema necesidad de lluvias que afectó al México central durante la década de 1760 no se dejó sentir en Durango, reportando únicamente la presencia de peste a fines de 1768 (AHAD, Libro XI; 
1768-1770, 22-XII-1768), e incluso refiere a junio de 1769 como un mes muy lluvioso (AHAD, Libro XI; 1768-1770, 27-VI-1769).

De acuerdo con los datos obtenidos en Durango para la década de 1770, esta parte del país tuvo una trayectoria climática más próxima a la del centro del país que a la del occidente. Años en que la Nueva Galicia en lo general no tuvo falta de lluvia, y el reino de México reportó marcados estiajes, tal y como se reconoció en los dos capítulos anteriores. Para julio de 1770 se solicita una rogativa (AHAD, Libro XI; 1768-1770, 21-VII-1770) que, aunque no se especificó el motivo, la redacción del documento y la época del año en que fue asentado invitan a pensar que se trató de un ceremonial pro pluvia. Dos años después, para fines de junio de 1772, quedó claramente especificada la necesidad de un ceremonial pro pluvia de nivel V (AHAD, Libro XII; 1770-1773, 26-VI-1772 y 30-VI-1772):

... en que hace presente ser necesario una procesión de rogativa, trayendo a la imagen de Jesús Nazareno a esta Santa Iglesia y que en ella se haga novenario, a cuyo fin se ha pasado oficio al señor Gobernador del reino, sin embargo de hallarse el cabildo ocupado en otro novenario a suplica de la ciudad a Nuestra Señora de los Remedios... (el novenario de la Virgen de los Remedios es el ceremonial anual preestablecido, solicitado por el obispado ante una posible falta de lluvias)... que se haga la procesión de Jesús Nazareno con las misas conventuales, con preces y la oración de la pluvia...

Aunque los extractos hallados para 1773 y 1775 (AHAD, Libro XII; 17701773, 25-VI-1773 y 30-VII-1773 y AHAD, Libro XIII; 1773-1775, 22-V-1775), no especifican las necesidades que obligaron a solicitar rogativas, existen de nuevo indicios, por la forma de redacción y época del año en que se condujeron los ceremoniales, que permiten inferir que es la falta de lluvias lo que las motivó. Asimismo, el México central sufrió la escasez de lluvias en esos mismos años (AACM y AHMP, extractos citados, 1773 y AACM, ACCM y AHMP, extractos citados, 1775). Cuatro años después (1779), la necesidad de precipitación pluvial dio lugar a un ceremonial pro pluvia (AHAD, Libro XIV; 1776-1782, 17-VIII-1779) de nivel IV.

La década de 1780 comenzó en Durango con una fuerte epidemia en el invierno y primavera de 1780 (AHAD, Libro XIV; 1776-1782, 26-II-1780 y 31-III1780). Situación que se repitió en el invierno de 1784 (AHAD, Libro XV; 17821787, 20-II-1784). En ambas ocasiones se condujeron ceremonias de rogativa con la finalidad de atajar la virulencia de los contagios. El denominado año del hambre en la Nueva España comenzó en Durango, con la presencia de una fuerte epidemia hacia la primavera (AHAD, Libro XV; 1782-1787, 19-IV-1785), manifes- 
tándose la extrema anomalía provocada por las cenizas del volcán Laki, al igual que en el México central y occidental (véanse capítulos anteriores), hacia fines del mes de agosto, lo que hizo necesario conducir ceremoniales de rogativa pro pluvia (AHAD, Libro XV; 1782-1787, 6-IX-1785) de nivel V a principios de septiembre.

Hacia el inicio de 1787 se reportaba que buena parte de las minas de la jurisdicción de Durango se encontraban abandonadas por causa de “... la esterilidad, falta de lluvias, peste y mortandad que han padecido estas provincias por el discurso de tres años..." (AHAD, Libro XV; 1782-1787, 13-II-1787), y para junio de ese año se oficializó una rogativa pro pluvia (AHAD, Libro XVI; 1787-1789, 22 VI-1787) de nivel V:

... el ilustrísimo señor Obispo hizo presente un oficio escrito a S.S.I. por el senoor Intendente y Ayuntamiento solicitando permiso para traer a esta Santa Iglesia la soberana imagen de Nuestra Seńora de Guadalupe para impetrar a Dios Nuestro Señor el beneficio de las aguas por su intercesión, se verifique desde luego la venida de la Santísima Señora el domingo próximo veinticuatro del corriente y que el siguiente día se comience el novenario...

Dos años después (1789), la aguda falta de lluvias sigue siendo grave: el 15 de junio (AHAD, Libro XVI; 1787-1789) se proclamó a santa Petronila como patrona de las aguas y el 25 de agosto a la virgen de Loreto con el mismo patronazgo, agregándosele la encomienda específica de "detener los hielos". Malos tiempos y carestía que refrendó el obispo de Durango el 7 de octubre de 1789 (AHAD, Libro XVI; 1787-1789). Las heladas tempranas parecen haber sido comunes entre 1785 y 1790 , prueba de ello es el siguiente extracto que detalla un ceremonial de rogativa de nivel V para atajar los hielos (AHAD, Libro XVI; 1787-1789, 8-X-1790):

... que se traiga en procesión a esta Santa Iglesia el próximo domingo diez del corriente la milagrosa imagen de María Santísima de Loreto, y se le cante misa solemne al siguiente día lunes, y en el mismo día por la tarde se traslade en la misma forma a la iglesia del señor San Francisco para que ahí se le haga un novenario de misas a fin de alcanzar del Todopoderoso por la intercesión de la soberana señora la detención de hielo, y que en lo sucesivo se celebre su función de patronato todos los ańos en el mes de septiembre...

Todo parece indicar que el quinquenio 1785-1790 fue más cruento hacia el noroeste del país que en el centro y occidente de México (véanse capítulos anteriores). En este sentido, cabe señalarse que el noroeste de México pudo estar 
a merced de dinámicas propias de las latitudes medias, en las que bajas temperaturas y falta de precipitación pueden asociarse a eventos climáticos consecuencia del capítulo eruptivo del Laki.

A las terribles heladas del otoño de 1790 les siguió un invierno muy crudo (AHAD, Libro XVI; 1787-1789, 20-I-1791) y, al parecer, después de tan funestos tiempos hubo dos años apacibles hasta el verano de 1794 , cuando volvieron a faltar las lluvias de manera extrema y se hizo necesario llevar a cabo ceremoniales pro pluvia (AHAD, Libro XVII; 1793-1799, 24-VII-1794) de nivel V, año que también fue anómalo en el centro de México (ACCM, ACMM y AHMM, extractos citados, 1794), al igual que el invierno y la primavera siguientes en esta misma zona del país (AACM, ACMM y AHMM, extractos citados, 1795), mientras que Durango reportó esterilidad a principios del verano de 1795 (AHAD, Libro XVII; 1793-1799, 7-VII-1795), por medio de un documento del archivo eclesiástico de esta ciudad, sin que quedase descripción alguna en cuanto a ceremoniales de rogativa. Tres años de calma siguieron a estos eventos, hasta que Durango fue víctima de una epidemia de viruelas durante el primer semestre de 1798 (AHAD, Libro XVII; 1793-1799, 26-I-1798, 10-V-1798, 18-V-1798 y 19-VI-1798), siendo el siguiente año (1799) bastante seco, situación que hizo necesario verificar un ceremonial pro pluvia para agosto (AHAD, Libro XVII; 1793-1799, 13-VIII-1799), evento cuya liturgia fue de nivel IV. Ese año fue particularmente cruento en cuanto a la falta de lluvias en el centro y occidente de México, aunque los ceremoniales correspondiente se realizaron en el mes de junio (AHMP, ACCM, ACMM, AHMM y ACCG extractos citados, 1799).

El inicio del siglo XIX al parecer fue más benevolente en Durango que en el centro de México y sólo el año de 1803 dio muestras de haber sido calamitoso, argumentando el propio extracto que para septiembre apenas se comenzaba a declarar como un mal año (AHAD, Libro XVIII; 1800-1806, 16-IX-1803). Así, Durango no da la alarma por escasez de lluvias por trece años, hasta el verano de 1816, cuando fue necesario llevar a cabo un ceremonial pro pluvia (AHAD, Libro XIX Bis; 1814-1816, 1-VIII-1816 y AHAD, Libro XX; 1812-1819, 4-VIII-1816) de nivel V. Como se observó en el capítulo dedicado al centro de México, la ciudad de Puebla (AHMP, extractos citados, 1815 y 1816), fue la única urbe que reportó alguna anomalía meteorológica durante el período eruptivo del volcán Tambora en Indonesia, mientras que Durango tuvo que recurrir al máximo ceremonial pro pluvia a la par que en Europa se vivía el llamado 'año sin verano'. Un mal temporal se presentó de nuevo, al igual que en el centro de México (AACM, ACCM y AHMP, extractos citados, 1818), dos años más tarde (1818) e hizo necesario un ceremonial pro pluvia (AHAD, Libro XX; 1812-1819, 22-IX-1818) de nivel V: 
... se conferenció entre ellos el del cumplimiento de la festividad jurada a la santísima Virgen de Loreto, implorando su intervención para con el Todopoderoso a que nos sea concedido el beneficio de la continuación de las lluvias y suspensión de los hielos, para que se logre el sermón de los frutos y se remedie en parte el perjuicio ocasionado por la escasez y variedad con que desde principio de la estación se han experimentado las citadas lluvias, con la urgencia que exige el tiempo. Cumplimiento de la fiesta de rogativa jurada a la Santísima Virgen de Loreto, que en la tarde de este día se traslade a esta santa Iglesia Catedral y en el día de mańana se cante en la misma la misa solemne acostumbrada, pasándola en la tarde en procesión al convento del Señor San Francisco para la continuación del novenario...que en los ańos siguientes se haga dicha fiesta en el día señalado, que es en el domingo tercero de septiembre; sino es que la urgente necesidad de suspensión de aguas exige anticiparla...

La ciudad de Durango del México independiente tuvo su primer ceremonial pro pluvia en el verano de 1823 (AHAD, Libro XXI; 1820-1824, 11-VII-1823), este de nivel III, pasando quince años sin que exista registro alguno de rogativas en esta urbe, hasta el otoño de 1838, cuando fuertes y tempranas heladas obligaron a recurrir a ceremonias de nivel V para solicitar "la suspensión de los hielos" (AHGD, Sala de Acuerdos, exp. 57; 1845, 25-X-1838). Dos años después (1840) fue indispensable, ante lo ardiente del verano de ese año, conducir rogativas pro pluvia (AHAD, Libro XXV; 1836-1846, 21-VIII-1840), funciones públicas de la Iglesia que se condujeron bajo las premisas de oficios de nivel IV. El siguiente invierno esta ciudad se vio asediada por la epidemia (AHAD, Libro XXV; 1836-1846, 1-II-1841), y el verano de ese ańo resultó tan ardiente que dos ceremoniales pro pluvia fueron llevados a cabo, uno en julio y el otro en agosto (AHAD, Libro XXV; 1836-1846, 16-VII-1841 y 18-VIII-1841), los primeros de nivel IV y los segundos de nivel III. De acuerdo con José Fernando Ramírez (1851: 4), entre 1837 y 1842 hubo fuertes nevadas cada año, mismas que se repitieron en los inviernos de 1847 y 1849. El transcurrir de la década de 1830 a la de 1840 fue también bastante severo en el centro y occidente de México (véanse capítulos anteriores). Cuatro años después (1845), se hizo necesario la realización de un nuevo ceremonial pro pluvia (AHAD, Libro XXV; 1836-1846, 4-VII-1845 y AHGD, Sala de Acuerdos, exp. 7; 1845, 1-VII-1845) de nivel V. El último ceremonial pro pluvia asentado en actas de cabildo en Durango fue conducido el 5 de julio de 1849 (AHAD, Libro XXVI; 1847-1859), y su liturgia fue de nivel V, para Ramírez (Ibid: 4) ese año hubo "falta total de aguas". Dos años después (1851), las heladas tempranas 
fueron de tal magnitud que fue necesario un ceremonial de nivel III para solicitar la "devención" de los hielos (AHGD, Sala de Acuerdos, exp. 10; 1851, 11-X-1851).

Las coincidencias entre otras partes de México y Durango en cuestiones ambientales, durante las décadas de 1820 y 1850, son las siguientes: a) en 1823 Puebla también tuvo que conducir un ceremonial pro pluvia, pero a diferencia de Durango, donde se condujo en el verano, en Puebla tuvo lugar durante la primavera de ese año (AHMP, extracto citado, 1823), b) en 1838 también México y Morelia reportaron un año anómalo (AACM, ACCM, ACMM y AHMM, extractos citados, 1838), c) en 1841, tanto Durango como las ciudades de México, Morelia y Puebla denunciaron tiempos muy secos (AACM, ACCM. ACMM y AHMP, extractos citados, 1841) y d) al igual que Durango, la Ciudad de México (ACCM, extracto citado, 1849) también recurrió a un ceremonial pro pluvia de nivel máximo en ese año.

\section{Sonora}

Lo tardío y escaso de los acervos de Sonora redujo la consulta en dicha entidad al Archivo General del estado de Sonora (AGES), que contiene datos aislados de índole climática, entre las décadas de 1830 y 1880 . Las deficiencias en cuanto a información obtenible a partir de fuentes primarias fue subsanada por medio de la consulta de fuentes secundarias que aportaron interesantes y complementarios datos para la década de 1880 y los primeros años del siglo XX. Por otra parte, cabe comentarse que en este apartado no se incluyen los capítulos epidémicos toda vez que en estos registros gubernamentales resultan datos aislados y no parte de un cuerpo documental continuo en el tiempo y homogéneo en su tipo de información, lo que dificulta su contrastación y ponderación con respecto a trayectorias climáticas.

Del ejercicio de consulta realizado en Hermosillo, se tiene que el primer registro climático obtenido corresponde al invierno de 1834, el cual fue extremadamente lluvioso desde el norte de Sinaloa hasta el centro de Sonora (AGES, Índice Ejecutivo tomo 47; Expediente 21, 4-II-1834 y Expediente 26, 13-II-1834). En contraposición, en el norte de Sonora se reportaba hacia el verano de 1837 extrema escasez de lluvias, misma que había obligado a abandonar los placeres de la jurisdicción de Altar (AGES, Fondo Ayuntamientos, caja 21, tomo 84, exp.3; 10-VIII-1837). El invierno de 1838 trajo fuertes nevadas a las sierras de Sonora, las cuales ocurrieron en su etapa más cruenta en el mes de febrero (AGES, Fondo Prefecturas, caja 24, tomo 92; 14-II-1838 y 21-II-1838). Área serrana, en la que 
a fines del verano del siguiente año (1839) se daba fe de un "fuerte temporal de aguas" (AGES, Fondo Prefecturas, caja 25, tomo 96; 22-IX-1839).

Los extremos climáticos registrados en el estado de Sonora durante la década de 1840 dan cuenta de un invierno y primavera muy secos en el desértico litoral central de dicho entidad en 1843 (AGES, Fondo Prefecturas, caja 36, tomo 134; 11-V-1843), y de fuertes precipitaciones hacia fines del verano siguiente en buena parte de la sierra Madre Occidental (AGES, Fondo Prefecturas, caja 30, tomo 112; 5-X-1843). Teniéndose asimismo, referencia de una fuerte salida de madre del río Yaqui en 1844, cuando varias comunidades de la etnia homónima tuvieron fuertes pérdidas materiales (AGES, Ayuntamientos-Prefecturas Caja 43 Tomo 156; 16-X-1845), reportándose los dos años siguientes (1845 y 1846) como muy secos en el norte del estado (AGES, Ayuntamientos-Prefecturas; 14-VI-1846). De la década de 1850 no se encontraron registros de índole climática en este estado. Siendo hasta el año de 1867 cuando se da cuenta de un rígido frente frío, que arrojó tal cantidad de agua que destruyó a la población de Caborca y obligó a buscar un nuevo sitio para su asentamiento (AGES, Índice Ejecutivo Tomo 83 Expediente 7; 14-I-1867 y 24-I-1867):

Inundación del pueblo de Caborca por la noche... ha sufrido en una inundación la pérdida total de su localidad. El 14 del corriente cosa de las 7 de la noche se notaba, que por consecuencia de una lluvia continua de tres días, salir de madre el río... y en menos de una hora, ya no tenía un lugar seco... La agua subió en el centro de la población cosa de dos varas... buscar otro lugar para reconstruir la población... Las tomas de agua para asegurar las siembras con el riego... han quedado perdidas... (24-I-1867) En la visita que he hecho a los pueblos de Pitiquito y Caborca, he tenido oportunidad de cerciorarme por mi propia vista de los desastres ocasionados por la lluvia y extraordinaria avenida del río, que puso fin al pueblo de Caborca y ocasionó inmensas perdidas al $\mathrm{Pi}$ tiquito y a todo el distrito en general...

La década de 1880 fue bastante anómala y abarcó diversas regiones del país. En este trabajo ya se hizo mención de las rogativas emprendidas en Morelia en la década de 1880 para intentar atajar la amenaza de la falta extrema de lluvias (ACMM, extractos citados, 1882 y 1884). Por su parte, en Sonora se encuentran registros de lo terrible que fueron para la agricultura y la ganadería de esta entidad los eventos de esta década: la primera noticia que se tiene cronológicamente fue la terrible seca que se vivió por aquellas latitudes entre 1882 y 1883, habiendo sido más acusada en el sur del estado hacía 1883, donde se perdieron ocho mil re- 
ses y tres mil equinos (Sociedad Sonorense de Historia, 1996: 234). La falta grave de lluvia volvió a repetirse en 1887 y de nuevo fue fuertemente acusada en el sur del estado, reportando Álamos que no había habido equipatas (lluvia invernal) entre 1886 y 1887 y que el temporal de verano simplemente no se presentó (Cuevas, 1989: 191). Por último, esta década dejó precipitaciones otoñales fuera de lo normal en noviembre de 1888 (Sociedad Sonorense de Historia, 1996: 234).

En este breve recuento sobre la variabilidad climática de Sonora durante el siglo XIX, destaca en una perspectiva de duración prolongada el aporte de José Murillo (1990: 65) en su historia de Guaymas. Obra en la que refiere los terribles daños en el puerto y sus embarcaciones como consecuencia de un ciclón el 4 de octubre de 1911. Jornada en el que la población, sin tener referente de la llegada de un huracán a estas latitudes en los últimos noventa años (el puerto de Guaymas se encontraba habitado de manera continua desde la década de 1820), pensó que se trataba del denominado cordonazo de San Francisco, fuertes tormentas que, en el imaginario popular, daban tradicionalmente fin a la temporada de lluvias en el México central y septentrional.

En este punto cabe señalarse que queda pendiente la consulta de las actas de cabildo civil de Monterrey y del obispados originalmente establecido en Linares, casi al mismo tiempo que en Sonora. El establecimiento tardío de este obispado y la escasa relevancia urbana de Monterrey hasta fines del siglo XIX, son indicadores de que los principios metodológicos seguidos y basados en el hallazgo de actas de cabildo que contengan registros continuos y prolongados no son válidos para esta parte del país. Aunque por supuesto, no se descarta a futuro la consulta de los acervos de Monterrey. 



\section{Capítulo 5. Chiapas y Yucatán}

\section{Chiapas}

Los resultados obtenidos tras la consulta de acervos en Mérida y San Cristóbal de las Casas son exiguos. Desafortunadamente, en el caso de la antigua capital de Chiapas se tiene que el actual palacio municipal (por aquel entonces era el palacio de gobierno de Chiapas) fue incendiado en 1863, en el marco de la Intervención Francesa, por tanto el acta de cabildo más antigua corresponde al año de 1875, por lo que se desechó su consulta. En cuanto al Archivo Diocesano de San Cristóbal de las Casas (ADSC), cuando se realizó la estancia de consulta en noviembre de 2009, la catalogación de ramos y documentos era muy básica, y el acceso a documentos era limitado debido al proceso de reorganización, que en general estaba viviendo este archivo. Resultado de dicha reorganización fue la publicación del Inventario del Archivo Histórico de la diócesis de San Cristóbal de las Casas, Chiapas (Cortés, 2010: 22-32), obra en la que se describen los ramos que componen este acervo y no contiene registros concernientes a actas de cabildo, fuera de los hallados durante la mencionada etapa de investigación (las actas encontradas no eran parte de volúmenes encuadernados, sino folios sueltos). Por tanto, no parece necesario volver a realizar una nueva estadía de consulta en la vieja Ciudad Real de Chiapa.

A pesar de la escasez de información, se obtuvieron datos interesantes que nos permiten reconocer cómo en Chiapas las dinámicas climáticas pueden diferir en un momento determinado con respecto a tendencias observadas en el centro y norte de México. Entre los documentos originales y los que publicó Andrés Aubry en el Boletín del Archivo Histórico Diocesano se encontró la siguiente información de índole climática y algunos extractos tocantes a la invasión de langosta, que como ya se observó es un fenómeno común al sureste de México (véase el capítulo 3). Los eventos documentados, mismos que abarcan de fines del siglo XVI a fines del siglo XIX, se han organizado por medio de los siguientes once puntos (Aubry, 1982: 19): 
1. Los primeros dos sucesos climáticos encontrados fueron proporcionados a Andrés Aubry por la antropóloga Dolores Aramonia y son parte de la obra Crónica de la Provincia del Santísimo Nombre de Jesús de Guatemala de la Orden de N. Seráfico Padre Francisco en el reino de la Nueva España, publicado en Guatemala en 1940. En ambos casos se trata de inundaciones, las cuales se tornan críticas ante la falta de un drenado abierto en el valle de Jovel, ya que este valle tiene como única salida para sus cauces dos socavones o sumideros; el segundo evento, por su parte, manifestó desprendimientos de lahares desde el cerro Huitepec, evento geomorfológico que en al menos tres ocasiones más se manifestó en esta elevación: a) "En el año de 1592 se anegó dicha ciudad, de suerte que peligraron muchas personas y totalmente se inundara si la buena diligencia ni hubiera acudido con tiempo, antes de que subiesen las aguas, a limpiar y destapar los ojos, o aberturas, quitando de ellos algunos animales muertos, maderos y piedras, que no dejaban pasar el agua..."

b) "No fue así en el año de 1651, por haber sido mayores las causas de ataparse y cegarse los cauces y respiraderos del agua. Fueron aquel año muchísimas las aguas en los fines del mes de septiembre y principios de octubre. Insensiblemente fue creciendo el daño, y tapándose los acueductos con las inmundicias... cuando una noche, cerca de la fiesta de N.P.S. Francisco, a deshora reventó un cerro que llaman Gueitepeque, que quiere decir cerro grande, y echando de si con gran violencia muchos ríos de agua y piedras muy grandes, rollizas y de todo género, llevadas éstas y muchos maderos de los árboles que cayeron, bestias muertas, y casas enteras del barrio de San Diego y San Antonio, toda esta broza atapó los sumideros de agua tan del todo, que siendo ya imposible el limpiarlos por haber subido el agua muchas varas en alto, crecía el daño por instantes, porque no cesaba de llover, ni de entrar los ordinarios ríos y aguas, y las que de nuevo salieron del reventado cerro... duró la inundación y peligro, que fueron más de treinta días... La ciudad por la parte baja era un mar, y los vivientes que se solían ver eran muchas aves marinas, y otros géneros de volátiles nunca visto en tierra. Los montes se veían poblados, aunque con tan corto albergue, que al agua que del cielo llovía bañaba a todos. Los nortes y vendavales eran tan desusados y nunca vistos, que a todos horrorizaban, lastimaban y presagiaban fatal acabamiento... al paso que cerrando los raudales de la reventazón del cerro y lluvias, y faltando la fuerza y copia de las aguas el entrar, y atenuándose las que estaban rebalsadas por comenzar ya a salir y desaguarse, dieron 
lugar a que pudiesen valer las diligencias para acabar de destapar las cinco aberturas, no sin grandísimo trabajo, pujanza de gente, y afanes que duraron muchos días, y aun socorriendo el peligro, quedó bien que haber para limpiar el mucho cieno ya podrido y pestilentemente hediondo que inficionaba el aire, causado de las inmundicias, animales y hombres muertos, que en treinta y tantos días que duró este horrible trabajo se empodrecieron...".

2. En el año de 1785 tuvo lugar de nuevo una catastrófica inundación en San Cristóbal de las Casas, de este evento se tienen las siguientes descripciones:

a) "Inundación de esta misma ciudad fue en el año de 1785, que comenzó la lluvia la noche del 29 de agosto del citado año y duró hasta el 2 de septiembre, que fue cuatro días sin cesar..." (ADSC, Diversos Asuntos, I.b.6s).

b) "Provino esta desgracia (y así sucederá en las demás) de haber llovido incesante, y reciamente desde la tarde del día 30 de agosto, hasta la mañana del viernes... 2 de septiembre. A esto se agregó el haber reventado un cerro que está enfrente de esta ciudad, nombrado vulgarmente Guitepeg... Las aguas que despidió en el tiempo de la lluvia este cerro, fueron tan cuantiosas que le abrieron por muchas partes de él, una grietas tan anchas, y profundas que le desfiguraron...” (Aubry, 1982: 20).

c) “... fue el 30 de agosto de 1785 , viniendo acompañado de un fuerte viento del Norte que, como un Eolo mitológico, destruía los edificios o los transformaba en lodo, en tierra, en fango... Hubo procesiones públicas en que el pueblo de aquel siglo rogaba la salvación de la ciudad, que era azotada por las olas del fuerte viento del Norte..." (Aubry, 1982: 22).

3. La tragedia se repitió cuatro años después, prácticamente por las mismas fechas, quedando la ciudad de San Cristóbal completamente inundada, así como los barrios indígenas que la rodeaban:

a) "... El expediente de todo lo operado, con motivo del diluvio que asaltó a esta ciudad el día primero de septiembre del corriente año... Después del pronto socorro de los necesitados, resta el reparo de los dos templos caídos, el de la Casa pública de recogidas, y el de muchos vecinos particulares que totalmente se asolaron...” (ADSC, Relación de 1789).

b) "El justicia mayor de ciudad acompaña a Vuestra Alteza el adjunto expediente en el que se contiene la solicitud que hacen los barrios de Mexicanos, San Antonio, y San Diego de los arrabales de esta ciudad, de que se les releve de la paga de tributos por años. La calamidad que alegan 
es cierta, por notoriedad, y también la acredita la certificación puesta a continuación de su escrito...”. Fechado el 3 de noviembre de 1789 (Aubry, 1982: 22).

4. Entre los datos que aportó Andrés Aubry (1989: 9), destaca la presencia de huracanes devastadores en el Soconusco en 1641, 1659 y 1794. Siendo tan violento el del último ańo, que obligó a trasladar la sede de poder provincial de Huehuetán a Tapachula.

5. Fuertes precipitaciones e inundación de San Cristóbal de las Casas en septiembre de 1825 (ADSC, Fondo Diocesano, Sección Gobierno, Clasificación II A, Acuerdos y Actas de cabildo; 1822-1842, septiembre de 1825).

6. Inundaciones en la cuenca del río Grijalva en 1834 (Aubry, 1982: 3).

7. Profundos y tempranos frentes fríos en el otońo de 1852 (ADSC, Libro de acuerdos y determinaciones del cabildo eclesiástico de esta Santa Iglesia Catedral de Ciudad Real de Chiapas; 1850-1885, 9-XI-1852).

8. Invasión de langosta en la primavera de 1854: "El cabildo de esta Santa Iglesia sabiendo que la terrible plaga de la langosta ha invadido a parte considerable de la diócesis y amenaza a toda ella; deseando aplacar la indignación Divina que con tanta justicia amenaza castigar nuestras culpas con esta y otras calamidades, ha acordado celebrar una rogativa pública en esta misma Santa Iglesia los días 26, 27 y 28 del corriente con misa solemne, exposición de su Divina Majestad y procesión cantándose en ella las preces correspondientes..." (Fondo Diocesano, Sección Gobierno, Clasificación II A; Acuerdos y Actas de cabildo; 1844-1897, 23-V1854). Documentos provenientes del ramo "Diversos Asuntos", ahondan en el impacto, duración y localización de esta terrible plaga, la cual duró hasta la primavera de 1855 y en las inmediaciones de San Cristóbal de las Casas invadió además de esta urbe a las poblaciones de Ecatepec y Teopisca (ADSC, I.b.6., 28 de mayo de 1854; 10 de febrero de 1855 y 24 de marzo de 1855).

9. Inundación: “... comenzó la lluvia y duró tres días, por lo que se creció el río... y bajó (el agua) hasta los catorce días...” (ADSC, Diversos Asuntos I.b.6, 1-IX-1864).

10. Inundación: “... a las tres de la tarde comenzó lentamente una lluvia, que en la noche del mismo día fueron fuertes aguaceros hasta el amanecer, hora en que ya estaban anegadas algunas casas del barrio de San Ramón, San Vicente y parte de La Merced, la lluvia continuó todo el día y en la tarde del 10 cayeron las casas de adobe, que estaban inmediatas 
al poniente... la lluvia cesó el sábado en la tarde, pero la creciente continuó... el río bajo completamente hasta el día 5 de noviembre..." (ADSC, Diversos Asuntos I.b.6, 8-X-1868).

11. Nuevos capítulos de inundación desde el cerro Huitepec en 1885 y 1888 (ADSC, Asuntos Civiles; 1888, I.c.4 e I.c.5)

Cabe señalarse, tomando en cuenta que no existe ningún tipo de continuidad y duración adecuada en los registros hallados en San Cristóbal de las Casas, que no se encontró ningún documento que señalase escasez de lluvias en esta parte de Chipas y, como quedó asentado, la mayor amenaza climática han sido los excesos hídricos que han inundado a la ciudad en repetidas ocasiones. A continuación se contrastan cuatro datos obtenidos en la antigua Ciudad Real de Chiapa con los del centro de México, lo que nos permite llegar a reconocer las marcadas diferencias meteorológicas en un momento determinado al este y al oeste del istmo de Tehuantepec:

1. Fines del verano de 1785; mientras que en el centro de México se reportaban fuertes y extemporáneas heladas (véase el capítulo 2), la entonces capital de Chiapas sufrió, como ya quedó asentado arriba, una de las más terribles inundaciones de su historia. Al contrastar con lo ocurrido simultáneamente en el centro de México, se entiende que masas de aire muy frío y extemporáneo influyeron en buena medida a que se desatara tan prolongado e intenso evento de precipitación.

2. Fines del verano de 1789; en esta ocasión, mientras Guadalajara y Morelia (véanse capítulos 2 y 3 ) reportaban una fuerte canícula, San Cristóbal de las Casas era víctima de nuevo de fuertes inundaciones.

3. En 1825, en el centro de México hubo escasez de lluvias hacia la mitad del año y Oaxaca también manifestó que 1825 fue un año seco (véanse capítulos 2 y 3). Por su parte, San Cristóbal de las Casas de nuevo fue víctima de fuertes inundaciones en septiembre de ese ańo.

4. Aunque tampoco conocemos con precisión los aspectos meteorológicos y fechas de los eventos, sabemos que durante 1834 hubo inundaciones en la cuenca del río Grijalva. En contrapartida, Morelia reportó extrema falta de lluvias hacia fines del verano (véase capítulo 2). 


\section{Yucatán}

En Mérida se consultaron el Archivo Histórico de la Arquidiócesis de Yucatán así como el Archivo General del Estado de Yucatán, ya que este acervo concentra toda la información histórica de los municipios yucatecos. La información obtenida en Yucatán, al igual que en la mayor parte de las ciudades fuera del centro de México, fue escasa, además de la falta de interés por preservar archivos y las vicisitudes político-militares del siglo XIX, en dicha entidad las condiciones climáticas de elevada humedad y temperatura no permitieron la preservación de gran número de documentos.

Yucatán, al igual que otras partes del sureste de México, no fue ajena a la plaga de langosta y en 1769 la intensidad y duración de este fenómeno obligó a traer a la virgen de Izamal hasta Mérida:

... relación de todo lo acontecido en la traída de la milagrosísima imagen de Nuestra Señora de Izamal a esta ciudad... para efecto de hacerse una pública rogativa, a fin de que halla la intercesión de la Reina de los Ángeles se aplacase la divina justicia, suspendiendo el castigo de innumerables langostas que rodeaban y talaban las milpas y montes de toda esta provincia... Primeramente fueron en busca de la Santísima Imagen a su pueblo (como es costumbre) de parte de la ciudad, dos regidores, y de parte de esta Iglesia con señores prebendados... y llegando a esta ciudad día 18 de junio, como a las nueve de la mańana, fue depositado en la iglesia del convento de La Mejorada, con prevención de que en la tarde del mismo día, había de ser traída procesionalmente a esta Iglesia Catedral; lo que no se efectuó por lo lluvioso de aquella tarde, reservándose la procesión para la mañana siguiente... Asistencia del obispo y las órdenes religiosas de San Francisco y San Juan de Dios que asistieron con sus patriarcas... el Gobernador y su ilustre Ayuntamiento... el día 20 de dicho mes comenzó el novenario... el día 29, siguiente feria del príncipe de los apóstoles Nuestro Padre San Pedro, el traslado de la Santa Imagen al convento de religiosas de esta ciudad... no se consiguió a causa de la lluvia... al día siguiente tampoco se logró por la misma causa... 10 de julio se trasladó al convento de religiosas de la ciudad... en donde se le hizo otro novenario... (AHAY, Actas del Cabildo Eclesiástico IV; 1761-1772, 29-VII-1769).

También en lo que toca a la invasión de la langosta se tiene un extracto correspondiente a 1774: “... habiéndose dignado la Divina Majestad por su infinita misericordia destruir la langosta que asolaba nuestros campos; decretó que en 
acción de gracias se cantase una misa solemne con asistencia de todo el clero de esta ciudad, estante y habitante, para lo cual asignaba el día 10 de octubre... y con asistencia también de las sagradas religiones y el ilustre cabildo secular..." (AHAY, Actas del Cabildo Eclesiástico V; 1772-1783, 27-IX-1774).

Por medio de los dos acervos consultados en Mérida, así como las consultas realizadas en el Centro de Apoyo a la Investigación Histórica de Yucatán, se propone una reconstrucción de las plagas de langosta ocurridas en la península de Yucatán entre el siglo XVI y principios del XX:

1. El año de 1552 hubo una asoladora plaga de langosta en los alrededores de Mérida. Ocurrió otra en 1618 (López Cogolludo, 1867: 352).

2. Año de 1648 (AHAY, Actas del Cabildo Eclesiástico IV; 1761-1772, 5-XII1769).

3. Hacia el inicio del verano de 1769 , las autoridades civiles y eclesiásticas de Mérida solicitan ceremonias de rogativa para que termine la plaga de langosta que aqueja a 'las milpas y montes' yucatecos (AHAY, extracto citado, 1769).

4. Cinco años después, al final del verano de 1774, la langosta volvió a asolar la parte norte de la península de Yucatán (AHAY, extracto citado, 1774).

5. Poco más de cien años después, se volvió a manifestar la presencia de la plaga de langosta en los municipios de Espitá, Izamal y Mérida (AGEY Espita, vol. 2, exp. 1/ 9-VII-1883; Izamal, vol. 4/ 20-XI-1882; Mérida, vol. 4/ 9-VII-1883). Habiendo un nuevo registro de invasión de langosta en 1906, aunque al parecer de menor duración y extensión (Menéndez, 1937: 249).

Un documento, también fechado en 1769, hace un recuento de las veces que la capital yucateca se sintió amenazada y tuvo que recurrir a ceremoniales de rogativa entre 1699 y 1770 (AHAY, extracto citado, 1769):

a) "En el año próximo pasado de noventa y nueve (1699) suspendiendo el castigo que merecen nuestras culpas correspondiente amenazaba en la general epidemia que se padecía de calentura ardiente y maligna, vomito de sangre, cursos violentos y otros accidentes graves... moría mucha gente, sin más duración de los enfermos, que de cinco a siete días y en cada día se enterraban más de veinte cuerpos... luego que se invocó su amparo (Señor de las Ampollas) celebrándole novenario solemne, se 
reconoció alivio y del todo la sanidad el día 9 de octubre que en procesión devotamente salió por la calle... y el que el día 5 de marzo de 1700 hizo al Santo Cristo de las Ampollas..."

b) Hambruna en Yucatán en 1770: “... antes de que llegasen los meses de junio y julio, en que se experimentan las calmas y turbonadas... respecto a la calamidad y pobreza con que se halla esta provincia venida de la universal hambre que padeció en el año pasado de setenta ..." (AHAY, Actas del Cabildo Eclesiástico IV; 1761-1772, 26-V-1772).

Como quedó asentado en el capítulo 2 de este trabajo, las décadas de 1760 y 1770 fueron bastante anómalas en el centro de México, y aunque carecemos de datos precisos, al parecer en Yucatán también se vivieron tiempos difíciles (Actas del Cabildo Eclesiástico V; 1772-1783):

a) “... novenario al Cristo de las Ampollas, sin que se especifique el motivo... le parecía conveniente que en los siete días que restaban de dicho novenario después de la misa cantada...” (2-X-1772).

b) “... en que da razón del encargo que su Señoría Ilustrísima y Venerable le hizo por la recaudación de diezmos del territorio de su visita asentado, que solamente se reducen a pagar por su escasez en especie y siendo la especie unos caballos..." (9-VI-1773).

c) “... ninguna ha conseguido aquella solemnidad con que en tiempos antiguos celebraban las fiestas de sus imágenes; el temor racional de unos años malos y fatales, que tan frecuentemente amenazan a nuestra patria..." (2-XI-1781).

Como bien se puede observar, los faltantes de información son muchos, pero a pesar de ello se pudo localizar al menos el registro de un ceremonial pro pluvia, el cual se asentó en 1872 (AHAY, Actas del Cabildo Eclesiástico XI; 1862-1874, 20-VII-1872): “... la circular que con fecha del 19 del mismo mes dirigió a los señores curas de las parroquias de la Diócesis ordenándoles que con el piadoso objeto de implorar de la misericordia del Señor el remedio de la actual escasez de lluvias, se hagan en los sábados, desde el siguiente al recibo de dicha circular, las preces que trae el ritual romano bajo el título "Deprecessione ad petendam pluviam" y se continúen practicando hasta el 31 de octubre del presente año. A efecto de que sea leída en esta Santa Iglesia Catedral dicha circular...”. 
Entre los datos obtenidos en el Archivo General del estado de Yucatán y referencias bibliográficas, vale la pena destacar la presencia de tres huracanes en 1834, 1868 y 1903:

1. "En vista de los estragos, causados por el temporal del día 4 de este mes en las sementeras de este pueblo (Motul) y consecuencias de escasez que ha de resentir el mismo de esta calamidad... permitir la introducción de granos del extranjero hasta el mes de noviembre... Telchac... podría continuar socorriendo a ese pueblo de su cargo con el pósito que tiene... mientras dure la necesidad de esos habitantes..." (AGEY, Municipio de Izamal, Libro 2; 1834-1841, 23-IX-1834).

2. "El ayuntamiento de esta capital tiene noticias positivas de que en toda la costa y en algunos pueblos del interior escasean los granos de primera necesidad a consecuencia de la pérdida absoluta de las sementeras el año pasado y teniendo fundados temores de que los pocos granos que existen sean monopolizados o retenidos en depósito por sus dueños, con el fin de realizarlos a un precio fabuloso... se digne decretar (la H. Legislatura del estado) si lo tiene por conveniente la libre importación de granos extranjeros hasta el mes de octubre, en que deberán cosecharse las sementeras del estado..." (AGEY, Municipio de Mérida, Libro 2; 1867-1868, 6-VII1868).

3. 13 de agosto de 1903. Es azotado el puerto de Progreso por una furiosa galerna del norte y el noreste, causando graves pérdidas materiales... El mismo temporal fue causa de la pérdida de la mayor parte de las sementeras de maíz y plantaciones de cańa en los partidos orientales de Espitá y Tizimín. La isla de Cozumel fue arrasada... solamente quedaron en pie tres casas; y en Puerto Morelos las olas del mar penetraron en las carboneras...” (Menéndez, 1937: 252).

Asimismo, se tienen registros de violentos 'nortes' ocurridos a fines del siglo XIX, ejemplo de ello y asentados por el grado de destrucción habida, se tienen los casos de Espitá en marzo de 1870 (Menéndez, 1937: 107) y Río Lagartos en febrero de 1891 (Menéndez, 1937: 68). 



\section{Conclusiones}

De acuerdo con los datos obtenidos por medio de la consulta de los registros de rogativa en las ciudades de México, Morelia, Puebla y Durango, se pueden definir dos parámetros primordiales en cuanto a una fuerte ausencia de precipitación: el retraso en el inicio de la temporada de lluvias (particularmente dramático si el invierno y primavera precedentes fueron extremadamente secos) y la interrupción de la temporada de lluvias o canícula. Esta última, mucho más evidente y persistente de acuerdo con la información recabada, durante la segunda mitad del siglo XVIII y primeras décadas del siglo XIX. Asimismo, las pulsaciones más evidentes de la Pequeña Edad de Hielo durante los siglos XVII, XVIII y XIX quedan bien definidas para el México central gracias a la documentación obtenida y el análisis de la misma (las gráficas y tablas anexas dan cuenta de ello).

Asimismo, al analizarse con detalle y de manera inter e intra anual el registro de los ceremoniales de rogativa, se puede definir tanto la duración como la intensidad de los eventos meteorológicos extremos bajo escrutinio. Labor a la que le es indispensable comparar la variabilidad 'normal' y estacional en el México central y meridional con las fechas en que las ceremonias de rogativa fueron propuestas y llevadas a cabo. Esta comparación ya ha sido sustentada por Hernández y Garza (2010), con información documental que abarca de circa 1600 a alrededor de 1870, en las ciudades de México y Puebla, con la precipitación promedio observada en el observatorio de Tacubaya de 1877 a 2007. Método que se basa en trazar las frecuencias como medias móviles en intervalos de 30 años, tal y como propuso la Organización Meteorológica Mundial en 1935 para los estudios tocantes a precipitación pluvial (Sanz-Donaire, 2000).

Hernández y Garza (2010: 103), con la idea de simplificar la representación de las cantidades obtenidas, se basan únicamente en datos correspondientes a los meses comprendidos entre abril y agosto, misma temporalidad que observan la mayor parte de los ceremoniales pro pluvia en las ciudades de México y Puebla. Basándose en estos parámetros, es factible proponer que la celebración de ceremonias de rogativa en abril era consecuencia de inviernos muy secos (enero a marzo), y que las conducidas en los meses de julio y agosto corresponden a la manifestación de fuertes canículas. 


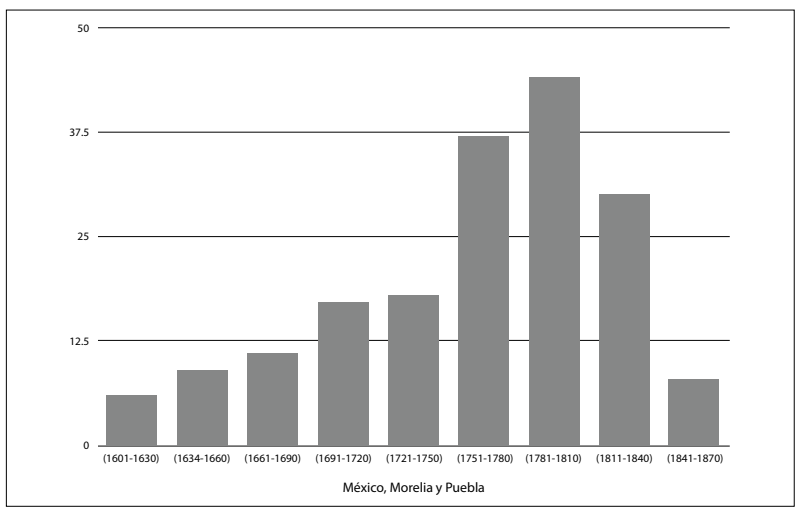

Figura 6. Total de rogativas pro pluvia niveles IV y $\mathrm{V}$, por períodos de 30 años entre 1601 y 1870 .

De acuerdo con la propuesta de Hernández y Garza, se puede resumir que la frecuencia y duración de los capítulos secos a fines del siglo XVII fue poco relevante, notándose un incremento a partir de la década de 1720, situación que se volvió más aguda a partir de la década de 1760, y se mantuvo hasta la década de 1800; a partir de entonces se registra de nuevo un régimen de precipitación relativamente más benevolente. Los resultados de tipo instrumental muestran, desde la década de 1870, un constante incremento en la precipitación; dinámica en la que estos autores reconocen, siguiendo a Jauregui (1995), la fuerte influencia de la extensa urbanización que ahoga al altiplano meridional de México.

En cuanto a un comportamiento mensual, entre 1597 y 1884 en las ciudades de México, Morelia y Puebla, se tiene que junio es el mes con el mayor número de rogativas pro pluvia de nivel $\mathrm{V}$ con un total de 49. A su vez, junio también cuenta con la cantidad más elevada de rogativas pro pluvia de nivel IV, las cuales suman

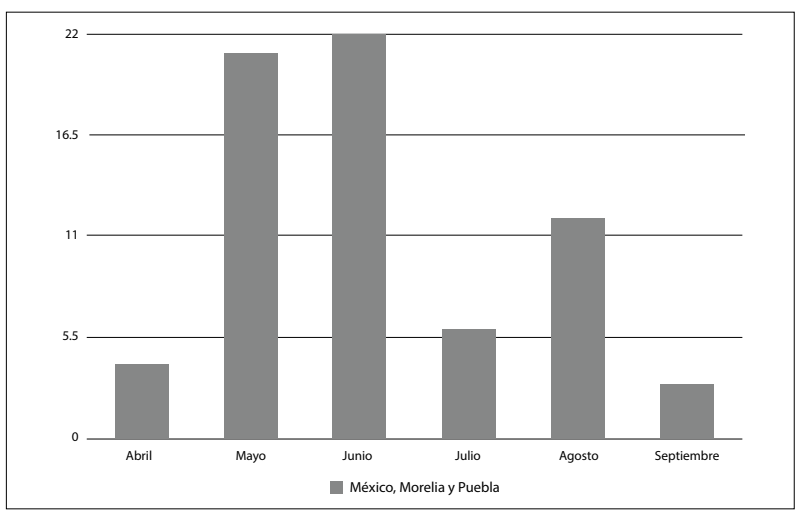

Figura 7. Número de rogativas pro pluvia de niveles IV y $\mathrm{V}$ (meses de abril a septiembre) entre 1597 y 1760. 


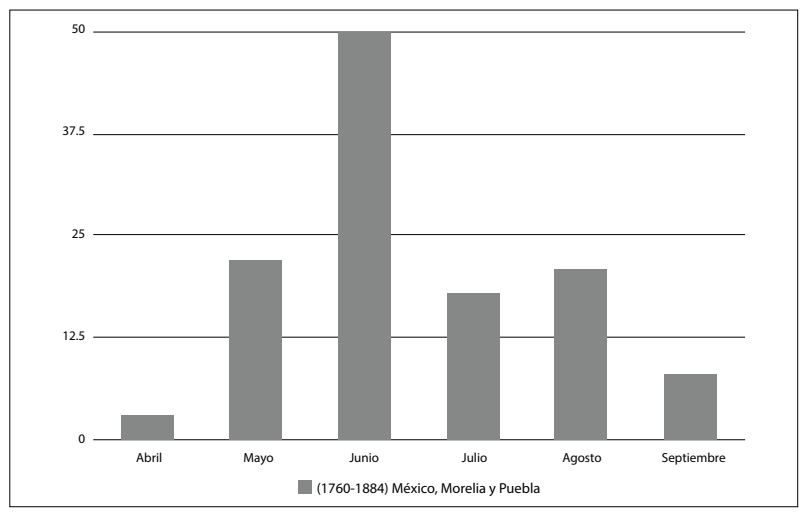

Figura 8. Número de rogativas pro pluvia de niveles IV y $\mathrm{V}$ (meses de abril a septiembre) entre 1760 y 1884 .

25. En el caso de las rogativas de nivel IV, no hay una gran diferencia con las realizadas en mes de mayo ya que estas conjuntaron 23 , mientras que las de nivel V fueron sólo 19. También fueron 19 las rogativas de nivel IV, asentadas durante el mes de agosto, y sólo 12 las registradas durante este mes de nivel V. El resto de los meses son, por mucho, poco representativos en cuanto al número de ceremoniales de rogativa que fueron conducidos. Es importante reconocer que alrededor del 60\% de las rogativas pro pluvia, llevadas a cabo durante el mes de agosto, fueron conducidas en la ciudad de Morelia, lo que permite inferir canículas más extremas en la capital de Michoacán, que en las ciudades de México y Puebla.

Por otra parte, al analizarse en términos temporales, el número de rogativas pro pluvia de nivel IV y V, se tienen comportamientos distintos antes y después de 1760. Entre 1597 y 1760, el número de ceremoniales de rogativa es prácticamente idéntico durante los meses de mayo (21) y junio (22), mientras que en agosto únicamente se conducen 10. Por el contrario, entre 1760 y 1884, son 50 los eventos religiosos de nivel IV y V durante el mes de junio, pero sólo 22 a lo largo del mes de mayo, alcanzándose en el mes de agosto la cantidad de 21 rogativas pro pluvia y 18 durante julio. Lo que hace evidente que la interrupción de la temporada de lluvias fue más común durante las últimas décadas del siglo XVIII y buena parte del siglo XIX. En ello también se debe tomar en cuenta años de ausencia casi total de precipitación, como ocurrió a mediados de las décadas de 1780 y 1810 .

En lo tocante a la labor futura destinada a la obtención de datos climáticos por medio de fuentes documentales entre los siglo XVII y XIX, se estima que existen unos 45 acervos municipales que deben ser analizados, primordialmente en el centro y sur de México, así como archivos parroquiales en urbes que, a partir del siglo XIX, se convirtieron en sedes obispales, mayoritariamente en el centro del país. 



\section{Anexo. Síntesis de cuatro siglos de información climática en México}

A continuación se presenta la síntesis de la información obtenida en diversas zonas de México (con excepción del noreste), la cual se exhibe por medio de veintiocho tablas que resumen los principales eventos registrados, tanto por su intensidad, como por su duración entre fines del siglo XVI y fines del siglo XIX:

Tabla 1. Período 1597-1600.

\begin{tabular}{clc}
\hline Año & \multicolumn{1}{c}{$\begin{array}{c}\text { México } \\
\text { Ayuntamiento }\end{array}$} & $\begin{array}{c}\text { Puebla } \\
\text { Ayuntamiento }\end{array}$ \\
\hline 1597 & $\begin{array}{l}\text { Rogativa de nivel V por salud } \\
\text { y buenos temporales (6-VIII-1597). }\end{array}$ & \\
1598 & $\begin{array}{l}\text { Fuertes heladas (5-I-1598). } \\
\text { Alegatos sobre esterilidad (12-VI-1598). }\end{array}$ & \\
1599 & & Fuertes precipitaciones (2-X-1598). \\
1600 & Necesidad de maíz (16-III-1600). & \\
\hline
\end{tabular}

Tabla 2. Período 1604-1609.

\begin{tabular}{|c|c|c|c|c|}
\hline Año & $\begin{array}{l}\text { México } \\
\text { Catedral }\end{array}$ & $\begin{array}{c}\text { México } \\
\text { Ayuntamiento }\end{array}$ & $\begin{array}{c}\text { Puebla } \\
\text { Ayuntamiento }\end{array}$ & $\begin{array}{c}\text { Guadalajara } \\
\text { Ayuntamiento }\end{array}$ \\
\hline 1604 & $\begin{array}{l}\text { Anegación } \\
\text { (reportada el } \\
\text { 3-IX-1607). }\end{array}$ & & & \\
\hline 1605 & & $\begin{array}{l}\text { Lluvias } \\
\text { en exceso } \\
\text { (reportadas el } \\
27-\mathrm{X}-1605 \text { ). }\end{array}$ & & $\begin{array}{l}\text { Plaga de hormigas } \\
\text { (16-VIII-1605). } \\
\text { Tal azote pudo ser } \\
\text { potenciado por } \\
\text { excesos hídricos. }\end{array}$ \\
\hline
\end{tabular}


120 - Sintesis de cuatro siglos de información climática en México

Tabla 2. Continúa.

\begin{tabular}{|c|c|c|c|c|}
\hline Año & $\begin{array}{l}\text { México } \\
\text { Catedral }\end{array}$ & $\begin{array}{c}\text { México } \\
\text { Ayuntamiento }\end{array}$ & $\begin{array}{c}\text { Puebla } \\
\text { Ayuntamiento }\end{array}$ & $\begin{array}{c}\text { Guadalajara } \\
\text { Ayuntamiento }\end{array}$ \\
\hline 1606 & & & $\begin{array}{l}\text { Carestía de } \\
\text { bastimentos } \\
\text { (19-VII-1606). }\end{array}$ & \\
\hline 1607 & & $\begin{array}{l}\text { Muchas aguas } \\
\text { (3-IX-1607), } \\
\text { mismas que se } \\
\text { prolongaron } \\
\text { hasta el } \\
\text { 28-IX-1607. }\end{array}$ & & \\
\hline 1608 & $\begin{array}{l}\text { Pocos y } \\
\text { malos trigos } \\
\text { (13-III-1608). }\end{array}$ & & & \\
\hline 1609 & $\begin{array}{l}\text { Rogativa pro pluvia } \\
\text { nivel III } \\
\text { (19-VI-1609). }\end{array}$ & & & \\
\hline
\end{tabular}

Tabla 3. Período 1616-1624.

\begin{tabular}{cclc}
\hline Año & \multicolumn{1}{c}{$\begin{array}{c}\text { México } \\
\text { Catedral }\end{array}$} & \multicolumn{1}{c}{$\begin{array}{c}\text { México } \\
\text { Ayuntamiento }\end{array}$} & \multicolumn{1}{c}{$\begin{array}{c}\text { Puebla } \\
\text { Ayuntamiento }\end{array}$} \\
\hline 1616 & & $\begin{array}{l}\text { Rogativa pro pluvia } \\
\text { y por peste nivel V } \\
\text { (7-VI-1616). }\end{array}$ & \\
1617 & & & \\
1618 & $\begin{array}{l}\text { Rogativa pro pluvia } \\
\text { nivel III } \\
\text { (24-IV-1618). }\end{array}$ & $\begin{array}{l}\text { Rogativa pro pluvia } \\
\text { nivel IV } \\
\text { (27-VII-1618). }\end{array}$ & \\
1619 & & $\begin{array}{l}\text { Barrios anegados } \\
\text { (31-VIII-1620). }\end{array}$ & $\begin{array}{l}\text { Puente de San Francisco } \\
\text { danado } \\
\text { (25-IX-1620). }\end{array}$ \\
1620 & & $\begin{array}{l}\text { Rogativa pro pluvia } \\
\text { de nivel IV } \\
\text { (28-V-1621). }\end{array}$ & \\
1621 & $\begin{array}{l}\text { Rogativa pro pluvia } \\
\text { de nivel V } \\
\text { (4-VI-1621). }\end{array}$ & & \\
1622 & & $\begin{array}{l}\text { Rogativa pro pluvia } \\
\text { nivel IV } \\
\text { (19-V-1623). }\end{array}$ & \\
\hline
\end{tabular}


Tabla 3. Continúa.

\begin{tabular}{cclc}
\hline Ańo & $\begin{array}{c}\text { México } \\
\text { Catedral }\end{array}$ & \multicolumn{1}{c}{$\begin{array}{c}\text { México } \\
\text { Ayuntamiento }\end{array}$} & $\begin{array}{c}\text { Puebla } \\
\text { Ayuntamiento }\end{array}$ \\
\hline 1624 & & $\begin{array}{l}\text { Rogativa pro pluvia } \\
\text { nivel IV } \\
(12-V I-1624) .\end{array}$ \\
\hline
\end{tabular}

Tabla 4. Período 1626-1630.

\begin{tabular}{|c|c|c|c|}
\hline Año & $\begin{array}{l}\text { México } \\
\text { Catedral }\end{array}$ & $\begin{array}{c}\text { México } \\
\text { Ayuntamiento }\end{array}$ & $\begin{array}{c}\text { Puebla } \\
\text { Ayuntamiento }\end{array}$ \\
\hline 1626 & $\begin{array}{l}\text { Rogativa pro pluvia } \\
\text { nivel III } \\
\text { (8-V-1626). }\end{array}$ & & \\
\hline 1627 & & $\begin{array}{l}\text { Heladas en Toluca a fines } \\
\text { de mayo y principios } \\
\text { de junio (11-VI-1627). } \\
\text { Rogativa pro serenitate } \\
\text { (25-VI-1627). } \\
\text { Continúan fuertes } \\
\text { precipitaciones } \\
\text { (9-VII-1627). } \\
\text { La ciudad inundada } \\
\text { (29-X-1627). }\end{array}$ & $\begin{array}{l}\text { Daños a la } \\
\text { cerca y puente } \\
\text { de San Francisco } \\
\text { (1-IX-1627). }\end{array}$ \\
\hline 1628 & & $\begin{array}{l}\text { No se cogió maíz } \\
\text { en Chalco y Toluca } \\
\text { (31-I-1628). }\end{array}$ & \\
\hline 1629 & $\begin{array}{l}\text { Rogativa contra las } \\
\text { inundaciones } \\
(4-\mathrm{X}-1626) .\end{array}$ & $\begin{array}{l}\text { Reportes sobre } \\
\text { inundaciones } \\
\text { (22 IX 1629-17-XII-1629). }\end{array}$ & \\
\hline 1630 & & $\begin{array}{l}\text { Reportes sobre } \\
\text { inundaciones } \\
\text { (8-II-1630-1-VIII-1630). }\end{array}$ & \\
\hline
\end{tabular}

Tabla 5. Período 1638-1644.

\begin{tabular}{|c|c|c|c|c|}
\hline Año & $\begin{array}{l}\text { México } \\
\text { Catedral }\end{array}$ & $\begin{array}{c}\text { México } \\
\text { Ayuntamiento }\end{array}$ & $\begin{array}{l}\text { Morelia } \\
\text { Catedral }\end{array}$ & $\begin{array}{c}\text { Puebla } \\
\text { Ayuntamiento }\end{array}$ \\
\hline 1638 & & & $\begin{array}{l}\text { Rogativa pro } \\
\text { pluvia nivel V } \\
(4-\mathrm{IX}-1638) .\end{array}$ & \\
\hline
\end{tabular}


122. Sintesis de cuatro siglos de información climática en México

Tabla 5. Continúa.

\begin{tabular}{|c|c|c|c|c|}
\hline Año & $\begin{array}{l}\text { México } \\
\text { Catedral }\end{array}$ & $\begin{array}{c}\text { México } \\
\text { Ayuntamiento }\end{array}$ & $\begin{array}{l}\text { Morelia } \\
\text { Catedral }\end{array}$ & $\begin{array}{c}\text { Puebla } \\
\text { Ayuntamiento }\end{array}$ \\
\hline 1639 & $\begin{array}{l}\text { El cabildo } \\
\text { eclesiástico } \\
\text { recibe } \\
\text { notificación para } \\
\text { la realización de } \\
\text { una rogativa } \\
\text { pro pluvia de } \\
\text { nivel III. }\end{array}$ & $\begin{array}{l}\text { Rogativa } \\
\text { pro pluvia } \\
\text { nivel III y contra } \\
\text { la peste } \\
\text { (9-VI-1639). } \\
\text { Para el día } \\
\text { 23-VI-1639, } \\
\text { ya han caído } \\
\text { cuatro aguaceros. }\end{array}$ & & \\
\hline \multicolumn{5}{|l|}{1640} \\
\hline 1641 & $\begin{array}{l}\text { Rogativa } \\
\text { pro pluvia } \\
\text { nivel V } \\
\text { (11-VI-1641). }\end{array}$ & $\begin{array}{l}\text { Rogativa } \\
\text { pro pluvia } \\
\text { nivel V } \\
\text { (16-VI-1641). }\end{array}$ & $\begin{array}{l}\text { Rogativa } \\
\text { propluvia } \\
\text { nivel IV } \\
\text { (14-VI-1641). }\end{array}$ & $\begin{array}{l}\text { “... mayor } \\
\text { decencia a } \\
\text { procesiones } \\
\text { por los buenos } \\
\text { temporales...” } \\
(6-V-1641) . \\
\text { Intensas lluvias } \\
(30-\text { VIII-1641). }\end{array}$ \\
\hline 1642 & $\begin{array}{l}\text { Rogativa } \\
\text { pro pluvia } \\
\text { nivel IV } \\
\text { (23-V-1642). } \\
\text { Rogativa } \\
\text { propluvia } \\
\text { nivel V } \\
\text { (29-VIII-1642). }\end{array}$ & $\begin{array}{l}\text { Rogativa nivel I } \\
\text { por peste } \\
\text { (29-III-1642). } \\
\text { Rogativa nivel II } \\
\text { pro pluvia y por } \\
\text { peste (9-V-1642). } \\
\text { Rogativa pro pluvia } \\
\text { nivel III } \\
\text { (15-V-1642). } \\
\text { Rogativa pro pluvia } \\
\text { nivel IV } \\
\text { (19-V-1642). } \\
\text { Rogativa pro pluvia } \\
\text { y por peste nivel III } \\
\text { (11-VIII-1642). } \\
\text { Rogativa pro pluvia } \\
\text { y por peste nivel V } \\
\text { (29-VIII-1642). }\end{array}$ & & $\begin{array}{l}\text { Intensas lluvias } \\
\text { (12-IX-1642). }\end{array}$ \\
\hline 1643 & & & & $\begin{array}{l}\text { “.. carestía } \\
\text { de trigo...” } \\
(11-\text { IX-1643). }\end{array}$ \\
\hline 1644 & $\begin{array}{l}\text { Rogativa pro } \\
\text { pluvia nivel III } \\
(20-\mathrm{V}-1644) .\end{array}$ & & & \\
\hline
\end{tabular}


Tabla 6. Período 1661-1663.

\begin{tabular}{cll}
\hline Año & \multicolumn{1}{c}{ México Catedral } & \multicolumn{1}{c}{ Puebla Ayuntamiento } \\
\hline 1661 & $\begin{array}{l}\text { Rogativa pro pluvia nivel II } \\
\text { (10-V-1661). } \\
\text { Rogativa pro pluvia nivel V } \\
\text { (10-VI-1661). }\end{array}$ \\
1662 & $\begin{array}{l}\text { Rogativas pro pluvia de nivel II } \\
\text { (9-V-1662 y 6-VI-1662). }\end{array}$ & \\
1663 & $\begin{array}{l}\text { Posible rogativa pro pluvia nivel V } \\
\text { (20-VI-1663). }\end{array}$ & $\begin{array}{l}\text { Rogativa pro pluvia nivel IV } \\
\text { (9-V-1663) }\end{array}$ \\
\hline
\end{tabular}

Tabla 7. Período 1666-1670.

\begin{tabular}{|c|c|c|c|c|}
\hline Año & $\begin{array}{l}\text { México } \\
\text { Catedral }\end{array}$ & $\begin{array}{l}\text { Morelia } \\
\text { Catedral }\end{array}$ & $\begin{array}{c}\text { Puebla } \\
\text { Ayuntamiento }\end{array}$ & $\begin{array}{l}\text { Durango } \\
\text { Catedral }\end{array}$ \\
\hline 1666 & $\begin{array}{l}\text { Negativa } \\
\text { del cabildo } \\
\text { eclesiástico para } \\
\text { llevar a cabo } \\
\text { rogativa pro } \\
\text { pluvia y por peste } \\
\text { de nivel V } \\
(6-I X-1666) \text {. }\end{array}$ & & & \\
\hline 1667 & & $\begin{array}{l}\text { Rogativa de } \\
\text { nivel III por } \\
\text { heladas fuertes } \\
(26-\text { IV-1667). }\end{array}$ & $\begin{array}{l}\text { Rogativa } \\
\text { pro pluvia } \\
\text { de nivel V } \\
\text { (1-VI-1667). }\end{array}$ & \\
\hline 1668 & & & $\begin{array}{l}\text { Rogativa } \\
\text { pro pluvia } \\
\text { de nivel IV } \\
\text { (11-VI-1668). }\end{array}$ & \\
\hline 1669 & $\begin{array}{l}\text { Rogativa pro } \\
\text { pluvia nivel III } \\
(21-\mathrm{V}-1669) .\end{array}$ & & & \\
\hline
\end{tabular}


124. Sintesis de cuatro siglos de información climática en México

Tabla 7. Continúa.

\begin{tabular}{|c|c|c|c|c|}
\hline Año & $\begin{array}{l}\text { México } \\
\text { Catedral }\end{array}$ & $\begin{array}{l}\text { Morelia } \\
\text { Catedral }\end{array}$ & $\begin{array}{c}\text { Puebla } \\
\text { Ayuntamiento }\end{array}$ & $\begin{array}{l}\text { Durango } \\
\text { Catedral }\end{array}$ \\
\hline 1670 & & & & $\begin{array}{l}\text { “... son continuos } \\
\text { de unos años } \\
\text { a esta parte las } \\
\text { tempestades, } \\
\text { piedra y rayos que } \\
\text { se manifiestan... } \\
\text { San Lorenzo } \\
\text { como patrón } \\
\text { contra estos males } \\
\text { a partir de este } \\
\text { año...” } \\
(22-\text { VIII-1670). }\end{array}$ \\
\hline
\end{tabular}

Tabla 8. Período 1682-1686.

\begin{tabular}{|c|c|c|}
\hline Año & $\begin{array}{l}\text { Morelia } \\
\text { Catedral }\end{array}$ & $\begin{array}{c}\text { Puebla } \\
\text { Ayuntamiento }\end{array}$ \\
\hline 1682 & & $\begin{array}{l}\text { Rogativa pro pluvia nivel IV } \\
(13-V-1682) \text {. }\end{array}$ \\
\hline 1683 & $\begin{array}{l}\text { Rogativa pro pluvia nivel III } \\
\text { (27-VII-1683). }\end{array}$ & $\begin{array}{l}\text { Rogativa pro pluvia nivel IV } \\
(5-\mathrm{V}-1683) \text {. }\end{array}$ \\
\hline 1684 & $\begin{array}{l}\text { Rogativa pro pluvia nivel IV } \\
(25 \text {-VIII-1684). }\end{array}$ & \\
\hline 1685 & $\begin{array}{l}\text { Rogativa pro pluvia nivel IV } \\
\text { (16-VI-1685). }\end{array}$ & \\
\hline 1686 & & $\begin{array}{l}\text { Rogativa pro pluvia nivel IV } \\
\text { (2-V-1686). } \\
\text { Rogativa pro pluvia nivel III } \\
\text { (4-IX-1686). }\end{array}$ \\
\hline
\end{tabular}

Tabla 9. Período 1691-1698.

\begin{tabular}{|c|c|c|c|c|c|}
\hline Año & 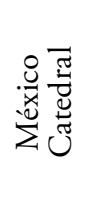 & 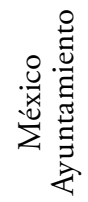 & 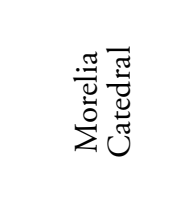 & 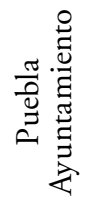 & 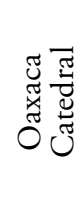 \\
\hline 1691 & & & $\begin{array}{l}\text { Año del } \\
\text { chahuixtle } \\
(16-\mathrm{VI}-1692) .\end{array}$ & & \\
\hline
\end{tabular}


Tabla 9. Continúa.

\begin{tabular}{|c|c|c|c|c|c|}
\hline Año & 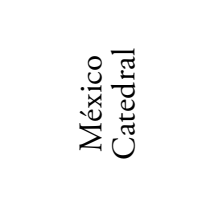 & 递蒂 & 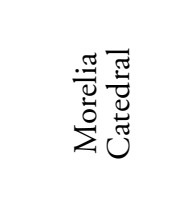 & 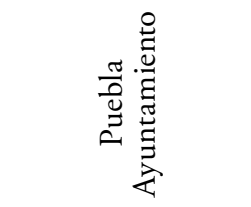 & 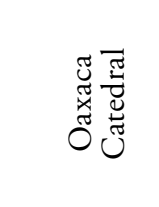 \\
\hline 1692 & $\begin{array}{l}\text { Gran } \\
\text { calamidad } \\
(19-I X-1692) .\end{array}$ & $\begin{array}{l}\text { Gran falta de } \\
\text { maíz } \\
(19-\text { IX-1692). }\end{array}$ & & $\begin{array}{l}\text { Rogativa pro } \\
\text { pluvia nivel V } \\
(17-\mathrm{V}-1692) \text {. } \\
\text { Malas cosechas } \\
\text { (2-IX-1692). } \\
\text { Malos temporales } \\
\text { desde } 1691 \\
(2-\mathrm{I}-1694) .\end{array}$ & \\
\hline 1693 & $\begin{array}{l}\text { Rogativa pro } \\
\text { pluvia y peste } \\
\text { nivel IV } \\
\text { (8-IV-1693). }\end{array}$ & & & & \\
\hline 1694 & $\begin{array}{l}\text { Rogativa pro } \\
\text { pluvia nivel V } \\
(8-\mathrm{VI}-1694) .\end{array}$ & & & & \\
\hline \multicolumn{6}{|l|}{1695} \\
\hline 1696 & $\begin{array}{l}\text { Rogativa } \\
\text { propluvia } \\
\text { nivel III } \\
\text { (7-V-1696). } \\
\text { Rogativa } \\
\text { pro pluvia } \\
\text { nivel V } \\
\text { (11-V-1696). } \\
\text { Rogativa } \\
\text { pro pluvia } \\
\text { nivel III } \\
\text { (25-V-1696). } \\
\text { Rogativa } \\
\text { pro pluvia } \\
\text { nivel IV } \\
\text { (27-V-1696). }\end{array}$ & & $\begin{array}{l}\text { Rogativa pro } \\
\text { pluvia nivel V } \\
(11-\mathrm{V}-1696) .\end{array}$ & $\begin{array}{l}\text { Casas dañadas } \\
\text { por la lluvia } \\
\text { (12-VII-1696). }\end{array}$ & \\
\hline 1697 & & & & $\begin{array}{l}\text { Desbordamineto } \\
\text { del río San } \\
\text { Francisco } \\
(15-X-1697)\end{array}$ & \\
\hline 1698 & & $\begin{array}{l}\text { Año } \\
\text { calamitoso } \\
\text { (7-IV-1698). }\end{array}$ & & & $\begin{array}{l}\text { Rogativa } \\
\text { propluvia } \\
\text { nivel IV } \\
\text { (5-V-1698). }\end{array}$ \\
\hline
\end{tabular}


126 - Sintesis de cuatro siglos de información climática en México

Tabla 10. Período 1717-1720.

\begin{tabular}{|c|c|c|c|c|c|}
\hline Año & 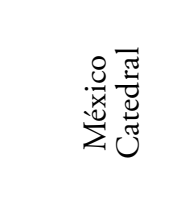 & 总 & 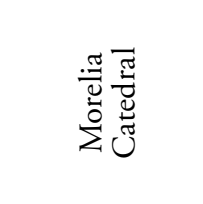 & 竞: & 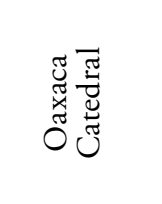 \\
\hline 1717 & $\begin{array}{l}\text { Rogativa } \\
\text { propluvia } \\
\text { nivel IV } \\
\text { (8-VI-1717). }\end{array}$ & & & & $\begin{array}{l}\text { Rogativa } \\
\text { pro pluvia } \\
\text { nivel IV } \\
\text { (7-VI-1717). }\end{array}$ \\
\hline 1718 & & $\begin{array}{l}\text { “...penoso de los } \\
\text { tiempos, muchas } \\
\text { enfermedades, } \\
\text { escasez de } \\
\text { trigos...” } \\
\text { (20-VII-1718). }\end{array}$ & & $\begin{array}{l}\text { “... escasez de } \\
\text { los tiempos”" } \\
\text { (12-VII-1718). }\end{array}$ & \\
\hline 1719 & & $\begin{array}{l}\text { Rogativa pro } \\
\text { pluvia nivel IV } \\
(5-\mathrm{VI}-1719) .\end{array}$ & $\begin{array}{l}\text { Rogativa por } \\
\text { los trigos } \\
\text { (1-III-1719). }\end{array}$ & & \\
\hline 1720 & $\begin{array}{l}\text { Rogativa } \\
\text { propluvia } \\
\text { nivel III } \\
\text { (18-VI-1720). }\end{array}$ & $\begin{array}{l}\text { Rogativa } \\
\text { propluvia nivel IV } \\
\text { (10-VI-1720). } \\
\text { Rogativa } \\
\text { propluvia nivel III } \\
\text { (1-VII-1720). }\end{array}$ & $\begin{array}{l}\text { Rogativa } \\
\text { propluvia } \\
\text { nivel V } \\
(20-\text { VIII-1720). }\end{array}$ & & \\
\hline
\end{tabular}

Tabla 11. Período 1733-1736.

\begin{tabular}{|c|c|c|c|}
\hline Año & $\begin{array}{c}\text { México } \\
\text { Ayuntamiento }\end{array}$ & $\begin{array}{c}\text { Puebla } \\
\text { Ayuntamiento }\end{array}$ & $\begin{array}{c}\text { Oaxaca } \\
\text { Ayuntamiento }\end{array}$ \\
\hline 1733 & $\begin{array}{l}\text { Rogativa pro pluvia } \\
\text { nivel IV } \\
\text { (29-VIII-1733). }\end{array}$ & $\begin{array}{l}\text { Rogativa pro pluvia } \\
\text { nivel V } \\
(2-\mathrm{X}-1733) \text {. }\end{array}$ & $\begin{array}{l}\text { Rogativa pro pluvia } \\
\text { nivel V } \\
(2-\mathrm{X}-1733) \text {. }\end{array}$ \\
\hline 1734 & $\begin{array}{l}\text { Rogativa pro pluvia } \\
\text { nivel III } \\
\text { (18-VI-1734). }\end{array}$ & & \\
\hline 1735 & $\begin{array}{l}\text { Rogativa pro pluvia } \\
\text { nivel IV } \\
\text { (20-VII-1735). }\end{array}$ & & \\
\hline 1736 & & $\begin{array}{l}\text { Rogativa pro pluvia } \\
\text { nivel IV } \\
\text { (7-VIII-1736). }\end{array}$ & \\
\hline
\end{tabular}


Tabla 12. Período 1739-1742.

\begin{tabular}{|c|c|c|c|c|c|c|}
\hline Año & 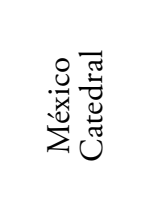 & 总 & 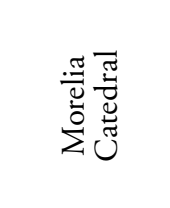 & 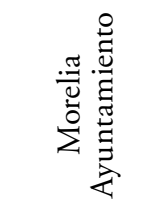 & 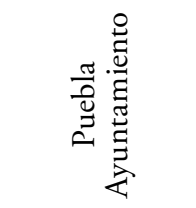 & 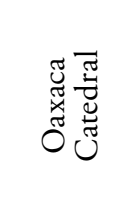 \\
\hline 1739 & & $\begin{array}{l}\text { Rogativa } \\
\text { pro pluvia } \\
\text { nivel III } \\
\text { (14-V-1739). } \\
\text { Rogativa } \\
\text { pro pluvia y } \\
\text { contra } \\
\text { los hielos } \\
\text { nivel III } \\
(26-V I- \\
1739) \text {. }\end{array}$ & $\begin{array}{l}\text { Mortandad } \\
\text { de ganados } \\
(10 \text {-VII- } \\
1739) \text {. }\end{array}$ & $\begin{array}{l}\text { Rogativa } \\
\text { pro pluvia } \\
\text { nivel V } \\
(9-\text { VII- } \\
1739) .\end{array}$ & $\begin{array}{l}\text { “... mayor } \\
\text { calamidad } \\
\text { y falta de } \\
\text { alimentos...” } \\
(14-X I-1739) .\end{array}$ & \\
\hline 1740 & & & $\begin{array}{l}\text { Rogativa } \\
\text { pro pluvia } \\
\text { nivel V } \\
(22-I X- \\
1740) .\end{array}$ & & $\begin{array}{l}\text { Carestía de } \\
\text { ganados } \\
(22-\mathrm{VI}-1740) . \\
\text { Cortedad de } \\
\text { cosechas } \\
(17-X I I-1740) .\end{array}$ & \\
\hline 1741 & & $\begin{array}{l}\text { Rogativa } \\
\text { pro pluvia } \\
\text { nivel II y III } \\
(4-\mathrm{V}-1741) .\end{array}$ & $\begin{array}{l}\text { Rogativa } \\
\text { pro pluvia } \\
\text { nivel IV } \\
(22-\text {-VII- } \\
1741) .\end{array}$ & & & $\begin{array}{l}\text { Rogativa } \\
\text { pro } \\
\text { pluvia } \\
\text { nivel IV } \\
\text { (20-VI- } \\
1741) .\end{array}$ \\
\hline 1742 & $\begin{array}{l}\text { Rogativa } \\
\text { pro pluvia } \\
\text { nivel IV } \\
\text { (29-V- } \\
\text { 1742). } \\
\text { Rogativa } \\
\text { pro pluvia } \\
\text { nivel V } \\
\text { (8-VI- } \\
1742) \text {. }\end{array}$ & $\begin{array}{l}\text { Rogativa } \\
\text { pro pluvia } \\
\text { nivel II } \\
\text { (28-V-1742). } \\
\text { Rogativa } \\
\text { pro pluvia } \\
\text { nivel IV } \\
\text { (4-VI-1742). }\end{array}$ & & & & \\
\hline
\end{tabular}


128 - Sintesis de cuatro siglos de información climática en México

Tabla 13. Período 1749-1751.

\begin{tabular}{|c|c|c|c|c|c|}
\hline Año & 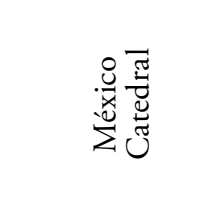 & 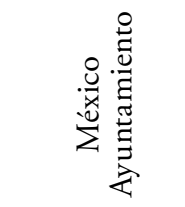 & 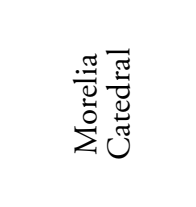 & 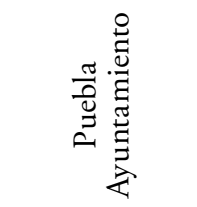 & 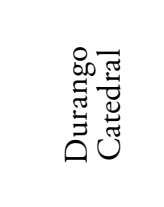 \\
\hline 1749 & & & $\begin{array}{l}\text { Rogativa } \\
\text { pro pluvia } \\
\text { nivel IV } \\
\text { (2-VI-1749). } \\
\text { Rogativa } \\
\text { pro pluvia } \\
\text { nivel V } \\
\text { (15-VII-1749). }\end{array}$ & & $\begin{array}{l}\text { Rogativa } \\
\text { pro pluvia } \\
\text { nivel V } \\
\text { (2-IX-1749). }\end{array}$ \\
\hline 1750 & $\begin{array}{l}\text { Rogativa pro } \\
\text { pluvia nivel III } \\
\text { (13-V-1750). } \\
\text { Rogativa pro } \\
\text { pluvia nivel V } \\
\text { (14-VI-1750). } \\
\text { Rogativa pro } \\
\text { pluvia nivel IV } \\
\text { (18-VIII-1750). } \\
\text { Seca severa, } \\
\text { especialmente } \\
\text { Tierra Adentro }\end{array}$ & $\begin{array}{l}\text { Rogativa } \\
\text { pro pluvia } \\
\text { nivel V } \\
(12 \text {-VI-1750). }\end{array}$ & & $\begin{array}{l}\text { Propuesta } \\
\text { de rogativa } \\
\text { pro pluvia } \\
\text { nivel IV } \\
(16-\text { IV-1750). }\end{array}$ & \\
\hline 1751 & & & & $\begin{array}{l}\text { Rogativa pro } \\
\text { pluvia nivel V } \\
(23-\mathrm{IV}-1751) .\end{array}$ & \\
\hline
\end{tabular}

Tabla 14. Período 1755-1763.

\begin{tabular}{|c|c|c|c|c|c|c|}
\hline Año & 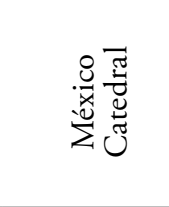 & 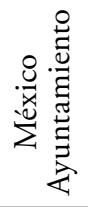 & 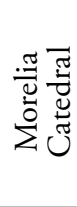 & 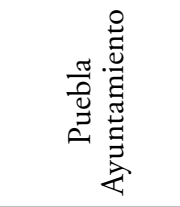 & 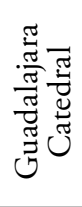 & 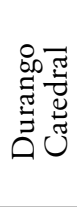 \\
\hline 1755 & $\begin{array}{l}\text { Rogativa } \\
\text { pro pluvia } \\
\text { nivel V } \\
(6-\mathrm{VI}-1755) .\end{array}$ & & & $\begin{array}{l}\text { Rogativa } \\
\text { pro pluvia } \\
\text { nivel IV } \\
(11-\mathrm{VI}-1755) \text {. }\end{array}$ & & \\
\hline
\end{tabular}


Tabla 14. Continúa.

\begin{tabular}{|c|c|c|c|c|c|c|}
\hline Año & 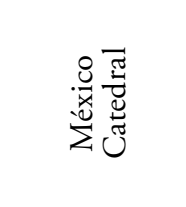 & 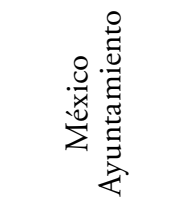 & 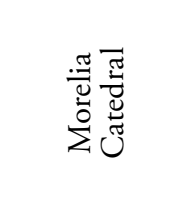 & 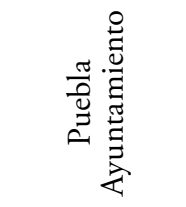 & 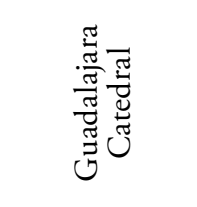 & 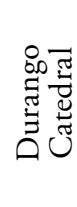 \\
\hline 1756 & & $\begin{array}{l}\text { Falta de } \\
\text { lluvias } \\
(8-V-1756)\end{array}$ & & $\begin{array}{l}\text { Rogativa } \\
\text { pro pluvia } \\
\text { nivel V } \\
(18-\mathrm{V}-1756) .\end{array}$ & $\begin{array}{l}\text { “... malos } \\
\text { tiempos, } \\
\text { delicadeces } \\
\text { de cosechas y } \\
\text { mortandad de } \\
\text { ganado...” } \\
(10-\text { IV-1756). }\end{array}$ & \\
\hline 1757 & & & & & & \\
\hline 1758 & & & & $\begin{array}{l}\text { Rogativa } \\
\text { pro pluvia } \\
\text { nivel IV } \\
\text { (21-VI-1758). }\end{array}$ & & \\
\hline 1759 & $\begin{array}{l}\text { Lluvia fuerte } \\
\text { por más de } \\
24 \text { horas } \\
(21-\mathrm{V}-1759) \text {. }\end{array}$ & & $\begin{array}{l}\text { Rogativa } \\
\text { pro pluvia } \\
\text { nivel III } \\
\text { (18-VI-1759). } \\
\text { Rogativa } \\
\text { pro pluvia } \\
\text { nivel IV } \\
\text { (15-IX-1759). } \\
\text { Rogativa pro } \\
\text { serenitatem } \\
\text { nivel IV } \\
\text { (9-X-1759). }\end{array}$ & & & \\
\hline \multicolumn{7}{|l|}{1760} \\
\hline 1761 & $\begin{array}{l}\text { Rogativa } \\
\text { pro pluvia } \\
\text { nivel IV } \\
\text { (9-VI-1761). } \\
\text { Rogativa } \\
\text { pro pluvia } \\
\text { nivel V } \\
\text { (19-VI-1761). }\end{array}$ & $\begin{array}{l}\text { Rogativa } \\
\text { pro pluvia } \\
\text { nivel V } \\
\text { (17-VI-1761). }\end{array}$ & $\begin{array}{l}\text { Rogativa } \\
\text { pro pluvia } \\
\text { nivel IV } \\
\text { (9-VI-1761). } \\
\text { Rogativa } \\
\text { pro pluvia } \\
\text { nivel V } \\
\text { (20-VI-1761). }\end{array}$ & $\begin{array}{l}\text { Rogativa } \\
\text { propluvia } \\
\text { nivel V } \\
\text { (6-VII-1761). }\end{array}$ & & \\
\hline 1762 & $\begin{array}{l}\text { Rogativa } \\
\text { pro pluvia } \\
\text { nivel III } \\
(22-I V-1762) \text {. }\end{array}$ & & & & & \\
\hline
\end{tabular}


Tabla 14. Continúa.

\begin{tabular}{|c|c|c|c|c|c|c|}
\hline Año & 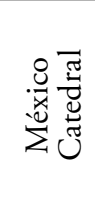 & 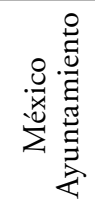 & 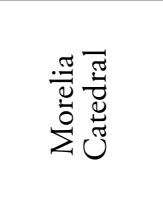 & 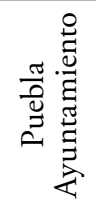 & 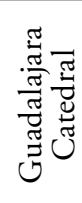 & 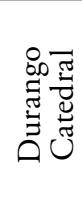 \\
\hline 1763 & & & $\begin{array}{l}\text { Rogativa } \\
\text { pro pluvia } \\
\text { nivel V } \\
\text { (9-VIII-1763). }\end{array}$ & & & \\
\hline
\end{tabular}

Tabla 15. Período 1766-1775.

\begin{tabular}{|c|c|c|c|c|c|c|}
\hline Año & 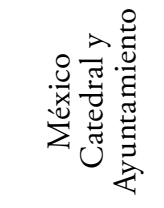 & 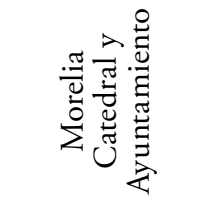 & 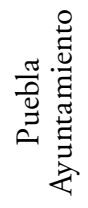 & 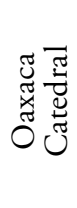 & 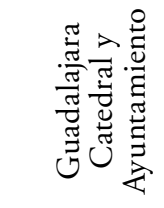 & 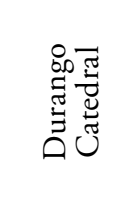 \\
\hline 1766 & & $\begin{array}{l}\text { Rogativa } \\
\text { pro pluvia } \\
\text { nivel V } \\
\text { (ACCM-20- } \\
\text { VI-1766). }\end{array}$ & & & & \\
\hline 1767 & $\begin{array}{l}\text { Rogativa } \\
\text { pro pluvia } \\
\text { nivel V } \\
\text { (ACCM-4- } \\
\text { VI-1767). }\end{array}$ & $\begin{array}{l}\text { Rogativa } \\
\text { pro pluvia } \\
\text { nivel IV } \\
\text { (ACCM- } \\
\text { 22-V-1767). }\end{array}$ & & & & \\
\hline 1768 & $\begin{array}{l}\text { Propuesta } \\
\text { de rogativa } \\
\text { pro pluvia } \\
\text { nivel V } \\
\text { (ACCM-10- } \\
\text { VI-1768). }\end{array}$ & & & & $\begin{array}{l}\text { Peste } \\
\text { (ACCG- } \\
\text { 21-X-1768). }\end{array}$ & $\begin{array}{l}\text { Rogativa } \\
\text { nivel IV } \\
\text { contra } \\
\text { la peste } \\
(22-X I I- \\
1768) .\end{array}$ \\
\hline 1769 & $\begin{array}{l}\text { Perdida de } \\
\text { trigos por } \\
\text { chahuixtle } \\
\text { en el reino } \\
\text { de México } \\
\text { y Tierra } \\
\text { Adentro } \\
\text { (ACCM- } \\
\text { 5-V-1769). }\end{array}$ & $\begin{array}{l}\text { Rogativa } \\
\text { pro pluvia } \\
\text { nivel IV } \\
\text { (ACCM- } \\
\text { 19-V-1769) } \\
\text { Chahuixtle } \\
\text { en Michoacán } \\
\text { (AHMM-12- } \\
\text { VI-1769). }\end{array}$ & & & & $\begin{array}{l}\text { Copiosas } \\
\text { lluvias } \\
\text { (27-VI- } \\
1769) \text {. }\end{array}$ \\
\hline
\end{tabular}


Tabla 15. Continúa.

\begin{tabular}{|c|c|c|c|c|c|c|}
\hline Año & 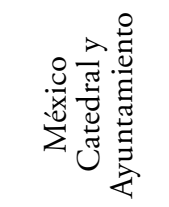 & 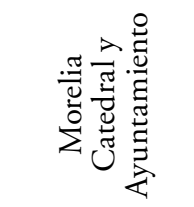 & 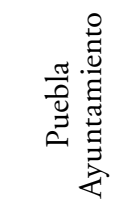 & 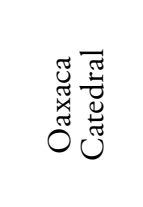 & 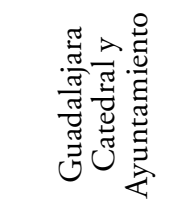 & 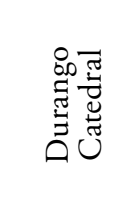 \\
\hline 1770 & $\begin{array}{l}\text { Rogativa } \\
\text { pro pluvia } \\
\text { nivel V } \\
\text { (ACCM- } \\
\text { 21-V-1770). }\end{array}$ & $\begin{array}{l}\text { Rogativa } \\
\text { pro pluvia } \\
\text { nivel V } \\
\text { (AHMM-11 al } \\
\text { 22-IX-1770). }\end{array}$ & $\begin{array}{l}\text { Plaga de } \\
\text { langosta } \\
(13 \text {-VII- } \\
1770) .\end{array}$ & & & $\begin{array}{l}\text { Posible } \\
\text { rogativa } \\
\text { pro } \\
\text { pluvia } \\
(21-\text { VII- } \\
1770) \text {. }\end{array}$ \\
\hline 1771 & $\begin{array}{l}\text { Rogativa } \\
\text { pro pluvia } \\
\text { nivel V } \\
\text { (ACCM-7- } \\
\text { VI-1771 y } \\
\text { ACCM-1- } \\
\text { VI-1771). }\end{array}$ & & $\begin{array}{l}\text { Rogativa } \\
\text { pro } \\
\text { pluvia } \\
\text { nivel V } \\
\text { (AHMP- } \\
\text { 6-VI- } \\
\text { 1771). }\end{array}$ & $\begin{array}{l}\text { Posible } \\
\text { rogativa } \\
\text { pro pluvia } \\
\text { nivel V } \\
\text { (11-VI- } \\
\text { 1771). }\end{array}$ & $\begin{array}{l}\text { Tempestades } \\
\text { (AHAG-22- } \\
\text { VI-1771) } \\
\text { Lluvias } \\
\text { en Nueva } \\
\text { Galicia } \\
\text { y sequía } \\
\text { en Nueva } \\
\text { España } \\
\text { (AHAG-29- } \\
\text { VII-1771). }\end{array}$ & \\
\hline 1772 & $\begin{array}{l}\text { Rogativa } \\
\text { pro pluvia y } \\
\text { por fiebres } \\
\text { nivel V } \\
\text { (ACCM y } \\
\text { AACM-3 y } \\
\text { 4-V-1772). }\end{array}$ & $\begin{array}{l}\text { Rogativa } \\
\text { pro pluvia } \\
\text { nivel V } \\
\text { (ACMM-3- } \\
\text { VI-1772). } \\
\text { Rogativas } \\
\text { pro pluvia } \\
\text { nivel III y IV } \\
\text { (ACMM-12- } \\
\text { VIII-1772). }\end{array}$ & $\begin{array}{l}\text { Rogativa } \\
\text { pro } \\
\text { pluvia } \\
\text { nivel V } \\
(27-\mathrm{V}- \\
1772) \text {. }\end{array}$ & & & $\begin{array}{l}\text { Rogativa } \\
\text { pro } \\
\text { pluvia } \\
\text { nivel V } \\
(26-\mathrm{VI}- \\
1772) \text {. }\end{array}$ \\
\hline 1773 & $\begin{array}{l}13,14 \text { y } \\
15 \text { abril, } \\
\text { heladas; } \\
\text { (AACM- } \\
24-V-1773 \text { ). }\end{array}$ & & $\begin{array}{l}\text { Rogativa } \\
\text { pro } \\
\text { pluvia } \\
\text { nivel IV } \\
\text { (9-VIII- } \\
\text { 1773). }\end{array}$ & & $\begin{array}{l}\text { Avenida } \\
\text { extraordinaria } \\
\text { río San Juan } \\
\text { de Dios } \\
\text { (AHAG-21- } \\
\text { VII-1773) } \\
\text { Lluvias en } \\
\text { Nueva Galicia } \\
\text { y sequía en } \\
\text { Nueva España } \\
\text { (AHAG- } \\
\text { 22-X-1773). }\end{array}$ & \\
\hline
\end{tabular}


Tabla 15. Continúa.

\begin{tabular}{|c|c|c|c|c|c|c|}
\hline Año & 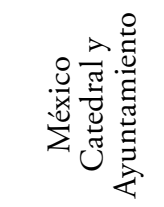 & 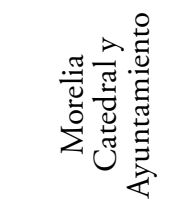 & 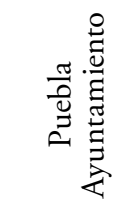 & 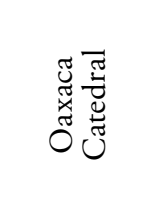 & 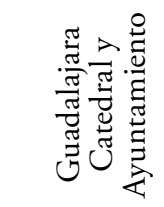 & 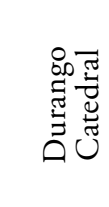 \\
\hline 1774 & $\begin{array}{l}\text { Propuesta } \\
\text { de rogativa } \\
\text { pro pluvia } \\
\text { (ACCM-16- } \\
\text { VI-1774). }\end{array}$ & $\begin{array}{l}\text { Rogativa } \\
\text { pro pluvia } \\
\text { nivel V } \\
\text { (AHMM-11- } \\
\text { VIII-1774). }\end{array}$ & & $\begin{array}{l}\text { Posible } \\
\text { rogativa } \\
\text { pro pluvia } \\
\text { nivel V } \\
\text { (20-IX- } \\
\text { 1774). }\end{array}$ & $\begin{array}{l}\text { Buenas } \\
\text { cosechas } \\
\text { (AHAG- } \\
\text { 29-X-1774). }\end{array}$ & \\
\hline 1775 & $\begin{array}{l}\text { Rogativa } \\
\text { pro pluvia } \\
\text { y por fiebre } \\
\text { nivel V } \\
\text { (ACCM- y } \\
\text { AACM, 16- } \\
\text { V-1775). }\end{array}$ & & $\begin{array}{l}\text { Rogativa } \\
\text { pro } \\
\text { pluvia } \\
\text { nivel IV } \\
(17-\text {-VI- } \\
1775) \text {. }\end{array}$ & & & $\begin{array}{l}\text { Posible } \\
\text { rogativa } \\
\text { pro } \\
\text { pluvia } \\
(22-\mathrm{V}- \\
1775) \text {. }\end{array}$ \\
\hline
\end{tabular}

Tabla 16. Período 1779-1781.

\begin{tabular}{|c|c|c|c|c|c|c|}
\hline Año & 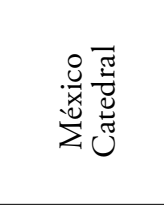 & 递兽 & 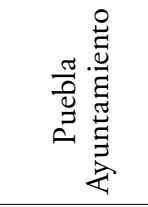 & 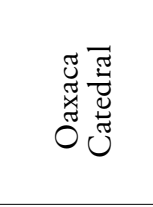 & 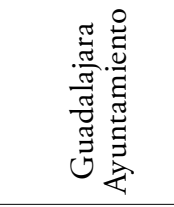 & 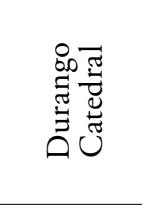 \\
\hline 1779 & $\begin{array}{l}\text { Rogativa } \\
\text { pro pluvia } \\
\text { nivel V } \\
\text { (inicio } \\
\text { 8-VI-1779). }\end{array}$ & $\begin{array}{l}\text { Rogativa } \\
\text { pro pluvia } \\
\text { nivel V } \\
\text { (fin 17-VI- } \\
\text { 1779). }\end{array}$ & $\begin{array}{l}\text { Rogativa } \\
\text { pro pluvia } \\
\text { nivel V } \\
\text { (7-VII- } \\
\text { 1779). } \\
\text { Escasez } \\
\text { de maíz y } \\
\text { trigo (6- } \\
\text { IX-1779). }\end{array}$ & & & \multirow[t]{2}{*}{$\begin{array}{l}\text { Rogativa } \\
\text { pro pluvia } \\
\text { nivel IV } \\
(17-\text { VIII- } \\
1779) .\end{array}$} \\
\hline 1780 & $\begin{array}{l}\text { Rogativa } \\
\text { pro pluvia } \\
\text { nivel V } \\
(20-\mathrm{V}- \\
1780) .\end{array}$ & & & $\begin{array}{l}\text { Posible } \\
\text { rogativa } \\
\text { pro pluvia } \\
\text { nivel V } \\
(10-\mathrm{VI}- \\
1780) .\end{array}$ & $\begin{array}{l}\text { Copiosas } \\
\text { lluvias } \\
\text { en } 1780 \\
(3-\mathrm{XI}-1780) \text {. }\end{array}$ & \\
\hline
\end{tabular}


Tabla 16. Continúa.

\begin{tabular}{|c|c|c|c|c|c|c|}
\hline Año & 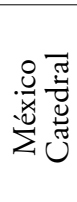 & 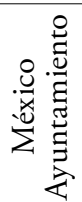 & 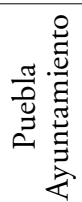 & 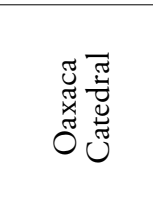 & 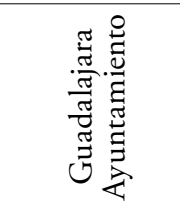 & 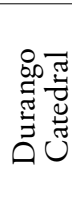 \\
\hline 1781 & & & & $\begin{array}{l}\text { Viruelas, } \\
\text { escasez y } \\
\text { estiaje (20- } \\
\text { VIII-1781). }\end{array}$ & $\begin{array}{l}\text { Mal } \\
\text { temporal } \\
\text { (1-VIII-1781). } \\
\text { Falta de } \\
\text { maíces } \\
\text { (27-IX-1781). }\end{array}$ & \\
\hline
\end{tabular}

Tabla 17. Período 1785-1787.

\begin{tabular}{|c|c|c|c|c|c|c|}
\hline Año & 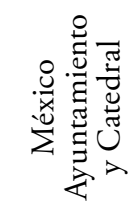 & 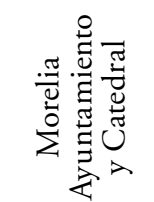 & 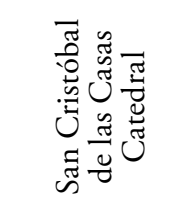 & 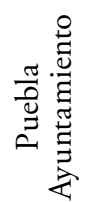 & 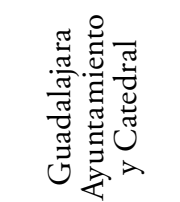 & 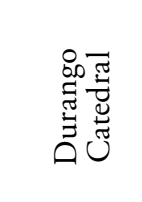 \\
\hline 1785 & $\begin{array}{l}\text { Rogativa } \\
\text { pro } \\
\text { pluvia } \\
\text { nivel V } \\
(11-V- \\
1785) .\end{array}$ & $\begin{array}{l}\text { Escasez de } \\
\text { agua en } \\
1785 \\
\text { (ACMM- } \\
20-\text { IV- } \\
1786 \text { ). }\end{array}$ & $\begin{array}{l}\text { "Inundación } \\
\text { de esta } \\
\text { misma } \\
\text { ciudad fue } \\
\text { en el año de } \\
1785 \text {, que } \\
\text { comenzó } \\
\text { la lluvia la } \\
\text { noche del } \\
29 \text { de agosto } \\
\text { del citado } \\
\text { año y duró } \\
\text { hasta el } 2 \text { de } \\
\text { septiembre, } \\
\text { que fue } \\
\text { cuatro días } \\
\text { sin cesar..." } \\
\text { (ADSC sin } \\
\text { fecha). }\end{array}$ & & $\begin{array}{l}\text { “... } \\
\text { mudanza del } \\
\text { temporal, } \\
\text { comenzaron } \\
\text { a escasear } \\
\text { las aguas } \\
\text { y se temen } \\
\text { heladas...” } \\
\text { (AHAG-27- } \\
\text { IX-1785). }\end{array}$ & $\begin{array}{l}\text { Rogativa } \\
\text { de nivel V } \\
\text { por peste } \\
\text { (19-IV- } \\
\text { 1785). } \\
\text { Rogativa } \\
\text { pro pluvia } \\
\text { de nivel } \\
\text { V (6-IX- } \\
\text { 1785). } \\
\text { Adelanto } \\
\text { de las } \\
\text { heladas } \\
(26-X- \\
1785) \text {. }\end{array}$ \\
\hline
\end{tabular}




\section{Tabla 17. Continúa.}

\begin{tabular}{|c|c|c|c|c|c|c|}
\hline Año & 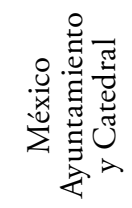 & 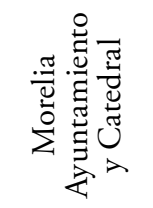 & 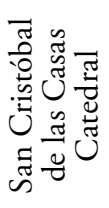 & 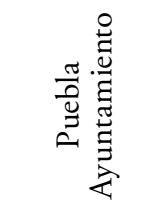 & 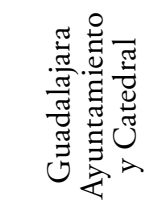 & 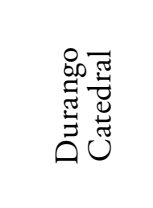 \\
\hline 1786 & $\begin{array}{l}\text { Rogativa } \\
\text { pro } \\
\text { pluvia } \\
\text { y peste } \\
\text { nivel V } \\
\text { (21-IV- } \\
1786) \text {. }\end{array}$ & $\begin{array}{l}\text { Escasez de } \\
\text { agua en } \\
1785 \\
\text { (ACMM- } \\
\text { 20-IV- } \\
1786) .\end{array}$ & & $\begin{array}{l}\text { Escasez de } \\
\text { abastos (4- } \\
\text { III-1786). } \\
\text { Epidemia } \\
\text { (19-IV- } \\
\text { 1786). }\end{array}$ & $\begin{array}{l}\text { Escasez de } \\
\text { alimentos } \\
\text { y epidemia } \\
\text { (AHAG-22- } \\
\text { IV-1786). } \\
\text { Escasez de } \\
\text { semillas } \\
\text { (ACCG-8- } \\
\text { III-1786). }\end{array}$ & \\
\hline 1787 & & $\begin{array}{l}\text { Malas } \\
\text { cosechas } \\
\text { en } \\
\text { Querétaro } \\
\text { y Celaya } \\
\text { (13-I- } \\
1787) \text {. }\end{array}$ & & & & $\begin{array}{l}\text { Peste y } \\
\text { falta de } \\
\text { lluvias en } \\
\text { la Sierra } \\
\text { Madre } \\
\text { Occidental } \\
\text { (13-II- } \\
\text { 1787). } \\
\text { Rogativa } \\
\text { pro pluvia } \\
\text { nivel V } \\
\text { (22-VI- } \\
\text { 1787). }\end{array}$ \\
\hline
\end{tabular}


Tabla 18. Período 1793-1795.

\begin{tabular}{|c|c|c|c|c|c|c|}
\hline Año & 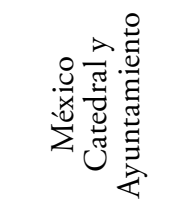 & 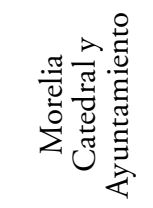 & 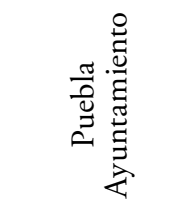 & 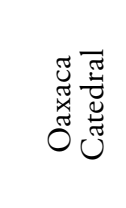 & 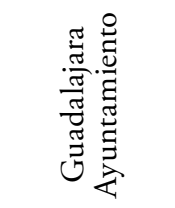 & 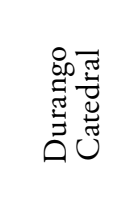 \\
\hline 1793 & $\begin{array}{l}\text { Propuesta } \\
\text { rogativa } \\
\text { pro pluvia } \\
\text { nivel III } \\
\text { (AACM-7- } \\
\text { VI-1793). }\end{array}$ & $\begin{array}{l}\text { Rogativa } \\
\text { pro pluvia } \\
\text { nivel IV } \\
\text { (ACMM y } \\
\text { AHMM-19 } \\
\text { y 20-VI- } \\
1793 \text { ). }\end{array}$ & $\begin{array}{l}\text { Carestía } \\
\text { de maíz } \\
\text { (13-IV-1793). } \\
\text { Viruelas (24- } \\
\text { IV-1793). } \\
\text { Comienzan } \\
\text { lluvias... “... } \\
\text { ya se había } \\
\text { llamado a } \\
\text { rogación...” } \\
\text { (14-VI-1793). }\end{array}$ & $\begin{array}{l}\text { Lluvias } \\
\text { (julio de } \\
1793 \text { ). }\end{array}$ & $\begin{array}{l}\text { Lluvias } \\
\text { (1-VI-1793). }\end{array}$ & \\
\hline 1794 & $\begin{array}{l}\text { Rogativa } \\
\text { pro pluvia } \\
\text { nivel V } \\
\text { (ACCM-6 al } \\
\text { 17-VI-1794). }\end{array}$ & $\begin{array}{l}\text { Rogativa } \\
\text { pro pluvia } \\
\text { nivel IV } \\
\text { (ACMM y } \\
\text { AHMM-8 } \\
\text { y 13-VI- } \\
\text { 1794). } \\
\text { Rogativa } \\
\text { pro pluvia } \\
\text { nivel V } \\
\text { (ACMM-5- } \\
\text { VII-1794). }\end{array}$ & & & $\begin{array}{l}\text { Rogativa } \\
\text { pro pluvia } \\
\text { niveles III y } \\
\text { IV-7 al 14- } \\
\text { VII-1794). } \\
\text { “... Bondad } \\
\text { de la } \\
\text { estación, } \\
\text { abundante } \\
\text { cosecha...” } \\
(6-X I- \\
1794) .\end{array}$ & $\begin{array}{l}\text { Rogativa } \\
\text { pro } \\
\text { pluvia } \\
\text { nivel V } \\
(24-\mathrm{VII}- \\
1794) .\end{array}$ \\
\hline 1795 & $\begin{array}{l}\text { Propuesta } \\
\text { de rogativa } \\
\text { pro pluvia } \\
\text { de nivel V } \\
\text { (AACM-12- } \\
\text { VI-1795). }\end{array}$ & $\begin{array}{l}\text { Rogativa } \\
\text { propluvia } \\
\text { nivel V } \\
\text { (ACMM y } \\
\text { AHMM } 17 \\
\text { y 19-VI- } \\
1795 \text { ). }\end{array}$ & $\begin{array}{l}\text { Abundancia } \\
\text { de lluvias } \\
\text { (agosto de } \\
\text { 1795). }\end{array}$ & & $\begin{array}{l}\text { “.. que las } \\
\text { presentes } \\
\text { aguas sean } \\
\text { fértiles...” } \\
(30-V I- \\
1795) .\end{array}$ & $\begin{array}{l}\text { Año } \\
\text { esteril } \\
\text { (7-VII- } \\
1795) .\end{array}$ \\
\hline
\end{tabular}


Tabla 19. Período 1798-1804.

\begin{tabular}{|c|c|c|c|c|c|}
\hline Año & 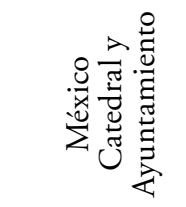 & 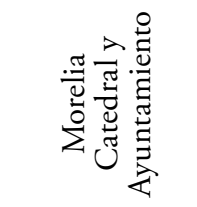 & 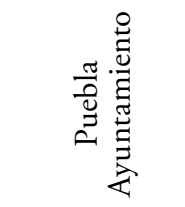 & 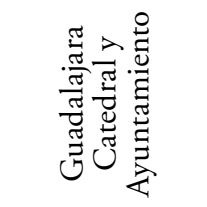 & 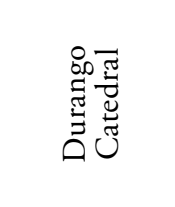 \\
\hline 1798 & $\begin{array}{l}\text { Rogativa } \\
\text { pro pluvia } \\
\text { nivel V } \\
\text { (ACCM-24- } \\
\text { VI-1798). }\end{array}$ & $\begin{array}{l}\text { Rogativa } \\
\text { pro pluvia } \\
\text { nivel IV } \\
\text { (ACMM-4- } \\
\text { VI-1798). }\end{array}$ & $\begin{array}{l}\text { Rogativa } \\
\text { pro pluvia } \\
\text { nivel V } \\
\text { (9-VI-1798). }\end{array}$ & & \\
\hline 1799 & $\begin{array}{l}\text { Rogativa } \\
\text { pro pluvia } \\
\text { nivel V } \\
\text { (ACCM-7- } \\
\text { VI-1799). }\end{array}$ & $\begin{array}{l}\text { Rogativa } \\
\text { propluvia } \\
\text { nivel IV } \\
\text { (ACMM y } \\
\text { AHMM-11 y } \\
\text { 12-VI-1799). }\end{array}$ & $\begin{array}{l}\text { Rogativa } \\
\text { pro pluvia } \\
\text { nivel V } \\
\text { (1-VI-1799). }\end{array}$ & $\begin{array}{l}\text { Escasez } \\
\text { de lluvias } \\
\text { (AHAG-10- } \\
\text { VI-1799). }\end{array}$ & $\begin{array}{l}\text { Rogativa } \\
\text { pro pluvia } \\
\text { nivel IV } \\
\text { (13-VIII- } \\
1799) .\end{array}$ \\
\hline 1800 & $\begin{array}{l}\text { Rogativa } \\
\text { pro pluvia } \\
\text { nivel V } \\
\text { (ACCM-9- } \\
\text { VI-1800). }\end{array}$ & $\begin{array}{l}\text { Rogativa pro } \\
\text { pluvia nivel V } \\
\text { (AHMM-23- } \\
\text { VI-1800). }\end{array}$ & & $\begin{array}{l}\text { Escasez de } \\
\text { lluvias (AHAG- } \\
\text { 21-VII-1800). }\end{array}$ & \\
\hline 1801 & $\begin{array}{l}\text { Rogativa } \\
\text { pro pluvia } \\
\text { nivel V } \\
\text { (ACCM y } \\
\text { AACM-27- } \\
\text { IV-1801). }\end{array}$ & $\begin{array}{l}\text { Rogativa } \\
\text { pro pluvia } \\
\text { nivel V } \\
\text { (ACCM- } \\
\text { 30-V-1801). }\end{array}$ & $\begin{array}{l}\text { Rogativa } \\
\text { pro pluvia } \\
\text { nivel V } \\
(28-\mathrm{V}-1801) \text {. }\end{array}$ & $\begin{array}{l}\text { Notoria } \\
\text { escasez } \\
\text { de lluvias } \\
\text { (ACCG- } \\
\text { 31-X-1801). }\end{array}$ & \\
\hline 1802 & $\begin{array}{l}\text { Rogativa } \\
\text { pro pluvia } \\
\text { nivel V } \\
\text { (ACCM y } \\
\text { AACM-10 } \\
\text { y } 11-\mathrm{V}-1802 \text { ). }\end{array}$ & & & & \\
\hline 1803 & & $\begin{array}{l}\text { Rogativa } \\
\text { pro pluvia } \\
\text { nivel V } \\
\text { (AHMM- } \\
\text { 8-VIII-1803). } \\
\text { Rogativa } \\
\text { pro pluvia } \\
\text { nivel IV } \\
\text { (ACMM y } \\
\text { AHMM-29 y } \\
\text { 30-VIII-1803). }\end{array}$ & & & $\begin{array}{l}\text { Escasez } \\
\text { de lluvias } \\
\text { (16-IX- } \\
1803) \text {. } \\
\text { Demasiadas } \\
\text { lluvias } \\
(14-X- \\
1803) \text {. }\end{array}$ \\
\hline
\end{tabular}


Tabla 19. Continúa.

\begin{tabular}{|c|c|c|c|c|c|}
\hline Año & 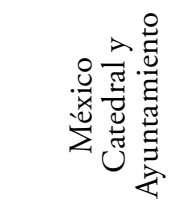 & 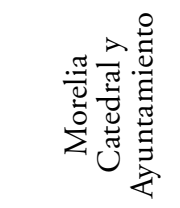 & 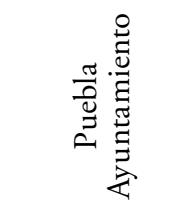 & 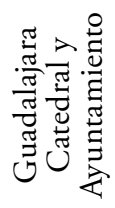 & 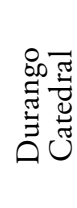 \\
\hline 1804 & $\begin{array}{l}\text { Rogativa } \\
\text { propluvia } \\
\text { nivel V } \\
\text { (ACCM-1- } \\
\text { VI-1804). }\end{array}$ & $\begin{array}{l}\text { Rogativa } \\
\text { propluvia } \\
\text { nivel V } \\
\text { (ACMM y } \\
\text { AHMM-26 y } \\
\text { 27-VI-1804). }\end{array}$ & $\begin{array}{l}\text { Rogativa } \\
\text { pro pluvia } \\
\text { nivel V } \\
\text { (ACCM- } \\
\text { 12-V-1804). }\end{array}$ & & \\
\hline
\end{tabular}

Tabla 20. Período 1807-1810.

\begin{tabular}{|c|c|c|c|c|c|c|}
\hline Año & 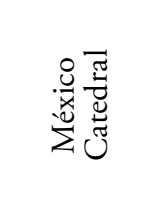 & 䒧 & 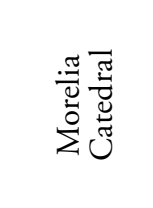 & 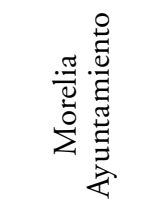 & 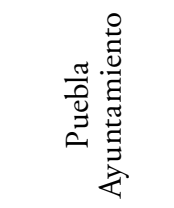 & 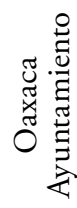 \\
\hline 1807 & & & $\begin{array}{l}\text { Rogativa } \\
\text { pro pluvia } \\
\text { nivel V } \\
\text { (4-VII- } \\
\text { 1807). } \\
\text { Rogativa } \\
\text { pro pluvia } \\
\text { nivel V } \\
\text { (14-IX- } \\
1807) .\end{array}$ & $\begin{array}{l}\text { Rogativa } \\
\text { pro pluvia } \\
\text { nivel V } \\
\text { (3-VII- } \\
\text { 1807). } \\
\text { Rogativa } \\
\text { pro pluvia } \\
\text { nivel V } \\
\text { (13-IX- } \\
\text { 1807). }\end{array}$ & & \\
\hline 1808 & $\begin{array}{l}\text { Rogativa } \\
\text { pro pluvia } \\
\text { nivel V } \\
\text { (19-VI- } \\
1808) \text {. }\end{array}$ & $\begin{array}{l}\text { Rogativa } \\
\text { pro pluvia } \\
\text { nivel V } \\
(18-\mathrm{VI}- \\
1808) .\end{array}$ & $\begin{array}{l}\text { Rogativa } \\
\text { pro pluvia } \\
\text { nivel V } \\
\text { (9-VI- } \\
1808) .\end{array}$ & & $\begin{array}{l}\text { Rogativa } \\
\text { pro pluvia } \\
\text { nivel V } \\
\text { (21-VI- } \\
1808) .\end{array}$ & \\
\hline 1809 & & & $\begin{array}{l}\text { Rogativa } \\
\text { pro pluvia } \\
\text { nivel V } \\
(10-X- \\
1809) .\end{array}$ & & $\begin{array}{l}\text { Novenario } \\
\text { sin motivo } \\
\text { especificado } \\
(10-\mathrm{VI}- \\
1809) .\end{array}$ & \\
\hline
\end{tabular}


Tabla 20. Continúa.

\begin{tabular}{|c|c|c|c|c|c|c|}
\hline Año & 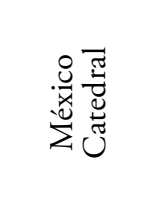 & 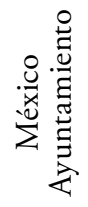 & 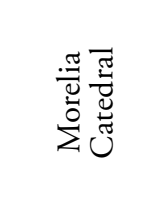 & 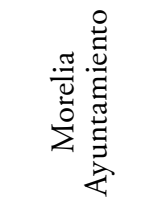 & 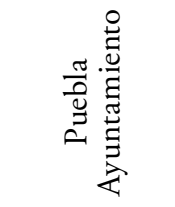 & 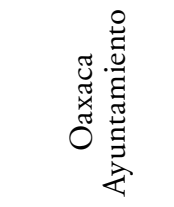 \\
\hline 1810 & $\begin{array}{l}\text { Rogativa } \\
\text { pro pluvia } \\
\text { nivel V } \\
(8-\mathrm{V}- \\
1810) \text {. } \\
\text { Rogativa } \\
\text { propluvia } \\
\text { nivel IV } \\
\text { (1-VI- } \\
1810) .\end{array}$ & & $\begin{array}{l}\text { Rogativa } \\
\text { pro pluvia } \\
\text { nivel IV } \\
(3-\text { VII- } \\
1810) .\end{array}$ & $\begin{array}{l}\text { Falta agua } \\
\text { (28-VI- } \\
1810) .\end{array}$ & $\begin{array}{l}\text { Presentes } \\
\text { necesidades } \\
(8 \text {-VI-1810). } \\
\text { “... escasez } \\
\text { universal...” } \\
(23 \text {-IX- } \\
1810) .\end{array}$ & $\begin{array}{l}\text { Abundancia } \\
\text { de lluvias } \\
\text { (13-VII- } \\
1810) \text {. }\end{array}$ \\
\hline
\end{tabular}

Tabla 21. Período 1816-1819.

\begin{tabular}{|c|c|c|c|c|c|}
\hline Año & 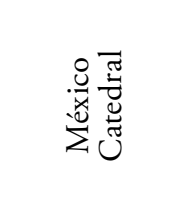 & 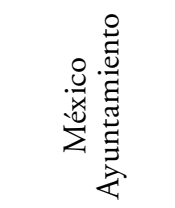 & 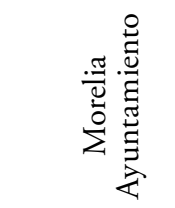 & 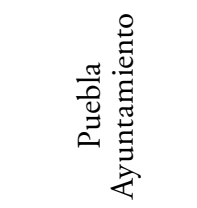 & 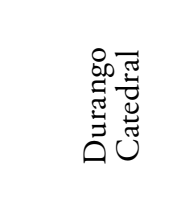 \\
\hline 1816 & & & & $\begin{array}{l}\text { Cortedad } \\
\text { de cosechas } \\
(10-\mathrm{V}-1816)\end{array}$ & $\begin{array}{l}\text { Rogativa } \\
\text { pro pluvia } \\
\text { nivel V } \\
(4-\mathrm{VIII}-1816)\end{array}$ \\
\hline 1817 & $\begin{array}{l}\text { Rogativa } \\
\text { pro pluvia } \\
\text { nivel V } \\
\text { (6-VI-1817). }\end{array}$ & $\begin{array}{l}\text { Rogativa } \\
\text { pro pluvia } \\
\text { nivel V } \\
\text { (6-VI-1817). }\end{array}$ & $\begin{array}{l}\text { Rogativa } \\
\text { pro pluvia } \\
\text { nivel V } \\
\text { (7-VI-1817). }\end{array}$ & & \\
\hline 1818 & $\begin{array}{l}\text { Rogativa } \\
\text { pro pluvia } \\
\text { nivel IV } \\
(29-\mathrm{V}-1818) .\end{array}$ & $\begin{array}{l}\text { Rogativa } \\
\text { pro pluvia } \\
\text { nivel IV } \\
\text { (29-V-1818). }\end{array}$ & & $\begin{array}{l}\text { Rogativa } \\
\text { pro pluvia } \\
\text { nivel V } \\
\text { (13-V-1818). }\end{array}$ & $\begin{array}{l}\text { Rogativa } \\
\text { pro pluvia } \\
\text { y suspensión } \\
\text { de los hielos } \\
\text { nivel V } \\
\text { (6-VI-1817). }\end{array}$ \\
\hline 1819 & $\begin{array}{l}\text { Rogativa } \\
\text { pro pluvia } \\
\text { nivel V } \\
(14-\mathrm{V}-1819) .\end{array}$ & & & $\begin{array}{l}\text { “.. llegada ya } \\
\text { la estación de } \\
\text { aguas...” } \\
(28-\mathrm{V}-1819) .\end{array}$ & \\
\hline
\end{tabular}


Tabla 22. Período 1822-1826.

\begin{tabular}{|c|c|c|c|c|c|}
\hline 题 & 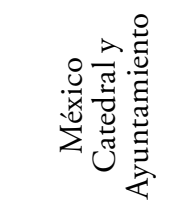 & 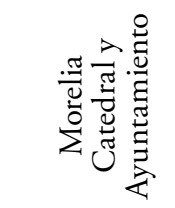 & 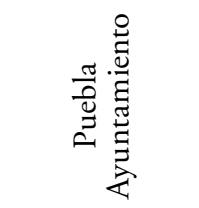 & 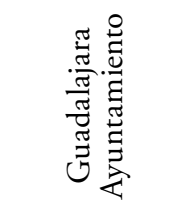 & 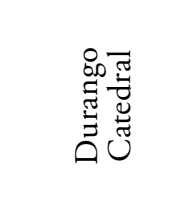 \\
\hline 1822 & $\begin{array}{l}\text { Rogativa } \\
\text { pro pluvia } \\
\text { niveles IV } \\
\text { y V (ACCM y } \\
\text { AACM-23 } \\
\text { y 28-VIII- } \\
1822) \text {. }\end{array}$ & & & & \\
\hline 1823 & & & $\begin{array}{l}\text { Posible } \\
\text { rogativa } \\
\text { pro pluvia } \\
\text { nivel IV } \\
(22-\mathrm{V}-1823) .\end{array}$ & & $\begin{array}{l}\text { Rogativa } \\
\text { pro pluvia } \\
\text { nivel III } \\
\text { (11-VII-1823). }\end{array}$ \\
\hline 1824 & & & $\begin{array}{l}\text { Rogativa } \\
\text { pro pluvia } \\
\text { nivel IV } \\
\text { (6-VIII-1824). }\end{array}$ & $\begin{array}{l}\text { Posible } \\
\text { rogativa } \\
\text { pro pluvia } \\
\text { nivel V } \\
(31-\mathrm{V}-1824) . \\
\text { “.. por } \\
\text { impedirlo } \\
\text { la corriente } \\
\text { de las aguas, } \\
\text { el temporal } \\
\text { en su mayor } \\
\text { fuerza...” } \\
\text { (9-VII-1824). }\end{array}$ & \\
\hline 1825 & $\begin{array}{l}\text { Rogativa } \\
\text { pro pluvia } \\
\text { nivel V } \\
\text { AACM- } \\
(7-V I-1825) \text {. }\end{array}$ & $\begin{array}{l}\text { Rogativa } \\
\text { pro pluvia } \\
\text { nivel V } \\
\text { (ACMM y } \\
\text { AHMM-12 y } \\
\text { 13-VI-1825). }\end{array}$ & & & \\
\hline 1826 & $\begin{array}{l}\text { Rogativa } \\
\text { pro pluvia } \\
\text { nivel V } \\
\text { (ACCM y } \\
\text { AACM-6 } \\
\text { y 8-VI-1826). }\end{array}$ & $\begin{array}{l}\text { Rogativa } \\
\text { pro pluvia } \\
\text { nivel V } \\
\text { (ACMM y } \\
\text { AHMM-29- } \\
\text { VIII y 1-IX- } \\
\text { 1826). }\end{array}$ & & & \\
\hline
\end{tabular}


140 - Sintesis de cuatro siglos de información climática en México

Tabla 23. Período 1833-1835.

\begin{tabular}{|c|c|c|c|c|}
\hline Año & 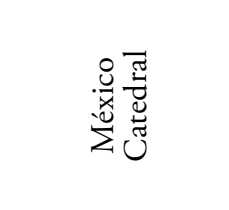 & 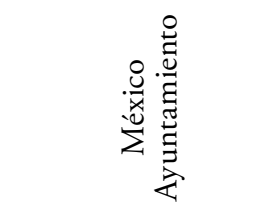 & 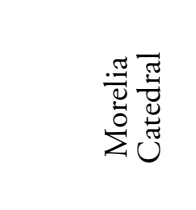 & 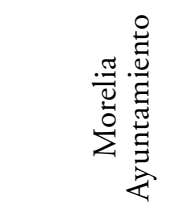 \\
\hline 1833 & $\begin{array}{l}\text { Posible rogativa } \\
\text { pro pluvia } \\
(26-\mathrm{VI}-1833)\end{array}$ & $\begin{array}{l}\text { Rogativa } \\
\text { pro pluvia } \\
\text { nivel V } \\
(2-\mathrm{V}-1833) .\end{array}$ & $\begin{array}{l}\text { Rogativa } \\
\text { pro pluvia } \\
\text { nivel III } \\
\text { (22-VI-1833). }\end{array}$ & \\
\hline 1834 & & $\begin{array}{l}\text { Propuesta de } \\
\text { rogativa pro pluvia } \\
\text { nivel V } \\
(18-\mathrm{VII}-1834) \text {. }\end{array}$ & $\begin{array}{l}\text { Rogativa } \\
\text { pro pluvia } \\
\text { nivel IV } \\
\text { (12-IX-1834). }\end{array}$ & $\begin{array}{l}\text { Rogativa } \\
\text { pro pluvia } \\
\text { nivel IV } \\
\text { (11-IX-1834). }\end{array}$ \\
\hline 1835 & $\begin{array}{l}\text { Rogativa } \\
\text { pro pluvia } \\
\text { nivel V } \\
\text { (4-VI-1835). }\end{array}$ & $\begin{array}{l}\text { Posible rogativa } \\
\text { pro pluvia } \\
\text { nivel V } \\
(16-V I-1835)\end{array}$ & $\begin{array}{l}\text { Rogativa } \\
\text { pro pluvia } \\
\text { nivel IV } \\
\text { (12-VI-1835). }\end{array}$ & $\begin{array}{l}\text { Rogativa } \\
\text { pro pluvia } \\
\text { nivel IV } \\
\text { (11-VI-1835). }\end{array}$ \\
\hline
\end{tabular}

Tabla 24. Período 1837-1841.

\begin{tabular}{|c|c|c|c|c|c|c|}
\hline Año & 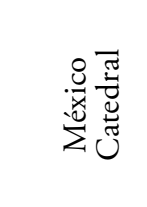 & 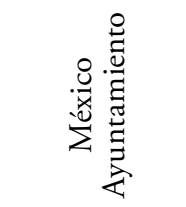 & 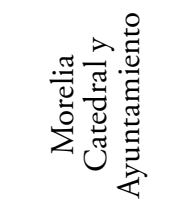 & 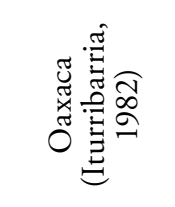 & 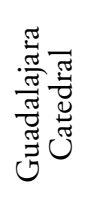 & 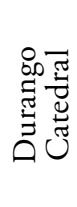 \\
\hline 1837 & & & $\begin{array}{l}\text { Rogativa } \\
\text { pro pluvia } \\
\text { nivel IV } \\
\text { (AHMM-21- } \\
\text { VI-1837). }\end{array}$ & $\begin{array}{l}\text { "Se hicieron } \\
\text { muchas } \\
\text { rogativas, } \\
\text { triduos y } \\
\text { novenarios, } \\
\text { implorando } \\
\text { el favor del } \\
\text { cielo para } \\
\text { que ese año } \\
\text { lloviera..." }\end{array}$ & & \\
\hline 1838 & $\begin{array}{l}\text { Rogativa } \\
\text { pro pluvia } \\
\text { nivel IV } \\
\text { (6-VII- } \\
\text { 1838). }\end{array}$ & $\begin{array}{l}\text { Rogativa } \\
\text { pro pluvia } \\
\text { nivel IV } \\
\text { (3-VII-1838). }\end{array}$ & $\begin{array}{l}\text { Rogativa } \\
\text { pro pluvia } \\
\text { nivel IV } \\
\text { (AHMM-11- } \\
\text { VII-1838). }\end{array}$ & & & \\
\hline
\end{tabular}


Tabla 24. Continúa.

\begin{tabular}{|c|c|c|c|c|c|c|}
\hline Año & 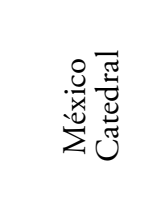 & 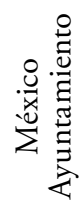 & 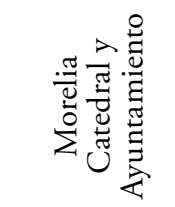 & 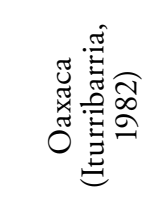 & 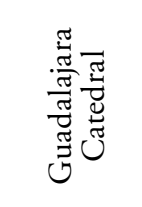 & 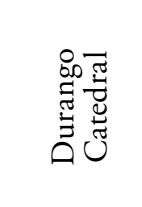 \\
\hline 1839 & $\begin{array}{l}\text { Rogativa } \\
\text { pro pluvia } \\
\text { nivel IV } \\
(18-\text {-VII- } \\
1839) .\end{array}$ & & $\begin{array}{l}\text { Rogativa } \\
\text { pro pluvia } \\
\text { nivel IV } \\
\text { (AHMM-15- } \\
\text { VII-1839). }\end{array}$ & $\begin{array}{l}\text { Rogativa } \\
\text { pro pluvia } \\
\text { nivel V } \\
\text { (sin fecha), } \\
\text { sin lluvias } \\
\text { en mayo y } \\
\text { junio }\end{array}$ & & \\
\hline 1840 & & & & & $\begin{array}{l}\text { Rogativa } \\
\text { pro pluvia } \\
\text { nivel IV } \\
(12-\text {-VIII- } \\
1840) \text {. }\end{array}$ & $\begin{array}{l}\text { Rogativa } \\
\text { pro pluvia } \\
\text { nivel IV } \\
(21-\text { VIII- } \\
1840) \text {. }\end{array}$ \\
\hline 1841 & $\begin{array}{l}\text { Rogativa } \\
\text { propluvia } \\
\text { nivel V } \\
(18-\mathrm{VII}- \\
1841) .\end{array}$ & & $\begin{array}{l}\text { Rogativa } \\
\text { pro pluvia } \\
\text { nivel III } \\
\text { (ACMM-20- } \\
\text { VII-1841). } \\
\text { Rogativa } \\
\text { pro pluvia } \\
\text { nivel V (13- } \\
\text { VIII-1841). }\end{array}$ & & $\begin{array}{l}\text { Posible } \\
\text { rogativa } \\
\text { pro pluvia } \\
\text { nivel III } \\
\text { (13-IX- } \\
\text { 1841). }\end{array}$ & $\begin{array}{l}\text { Rogativa } \\
\text { pro pluvia } \\
\text { nivel IV } \\
\text { (16-VII- } \\
1841) \text {. } \\
\text { Rogativa } \\
\text { pro pluvia } \\
\text { nivel III } \\
\text { (18-VIII- } \\
1841) \text {. }\end{array}$ \\
\hline
\end{tabular}

Tabla 25. Período 1845-1846.

\begin{tabular}{ccccc}
\hline Año & $\begin{array}{c}\text { México } \\
\text { Catedral }\end{array}$ & $\begin{array}{c}\text { México } \\
\text { Ayuntamiento }\end{array}$ & $\begin{array}{c}\text { Morelia } \\
\text { Catedral }\end{array}$ & $\begin{array}{c}\text { Durango } \\
\text { Catedral }\end{array}$ \\
\hline 1845 & & & $\begin{array}{l}\text { Rogativa } \\
\text { propluvia } \\
\text { nivel V } \\
\text { (4-VII-1845). }\end{array}$ \\
1846 & $\begin{array}{l}\text { Propuesta } \\
\text { de rogativa } \\
\text { propluvia } \\
\text { (23-V-1846) }\end{array}$ & $\begin{array}{l}\text { Propuesta } \\
\text { de rogativa } \\
\text { propluvia } \\
\text { nivel III } \\
(16-\text {-VI-1846) }\end{array}$ & $\begin{array}{l}\text { Rogativa por } \\
\text { causa de } \\
\text { las heladas } \\
\text { nivel V } \\
\text { (9-X-1846). }\end{array}$ & \\
\hline
\end{tabular}


142 - Sintesis de cuatro siglos de información climática en México

Tabla 26. Período 1854-1857.

\begin{tabular}{|c|c|c|c|c|}
\hline Año & $\begin{array}{l}\text { México } \\
\text { Catedral }\end{array}$ & $\begin{array}{c}\text { México } \\
\text { Ayuntamiento }\end{array}$ & $\begin{array}{l}\text { Morelia } \\
\text { Catedral }\end{array}$ & $\begin{array}{c}\text { Morelia } \\
\text { Ayuntamiento }\end{array}$ \\
\hline 1854 & $\begin{array}{l}\text { Rogativa } \\
\text { pro pluvia } \\
\text { nivel IV } \\
\text { (30-V-1854). } \\
\text { Rogativa contra } \\
\text { calamidades } \\
\text { nivel III } \\
(4-\mathrm{VII}-1854) .\end{array}$ & $\begin{array}{l}\text { Propuesta } \\
\text { de rogativa } \\
\text { pro pluvia } \\
\text { nivel III } \\
(24-\mathrm{V}-1854) .\end{array}$ & $\begin{array}{l}\text { Rogativa } \\
\text { pro pluvia } \\
\text { nivel III } \\
\text { (14-VII-1854). } \\
\text { Rogativa } \\
\text { pro pluvia } \\
\text { nivel V } \\
\text { (2-VIII-1854). }\end{array}$ & $\begin{array}{l}\text { Rogativa } \\
\text { pro pluvia } \\
\text { nivel V } \\
(17-\mathrm{VI}-1854) .\end{array}$ \\
\hline \multicolumn{5}{|l|}{1855} \\
\hline 1856 & $\begin{array}{l}\text { Rogativa } \\
\text { pro pluvia } \\
\text { nivel IV } \\
\text { (31-VIII-1856). }\end{array}$ & & & \\
\hline 1857 & & $\begin{array}{l}\text { Posible rogativa } \\
\text { pro pluvia } \\
\text { nivel IV } \\
\text { (12-VII-1857). }\end{array}$ & & \\
\hline
\end{tabular}

Tabla 27. Período 1870-1872.

\begin{tabular}{clll}
\hline Año & \multicolumn{1}{c}{$\begin{array}{c}\text { Morelia } \\
\text { Catedral }\end{array}$} & \multicolumn{1}{c}{$\begin{array}{c}\text { Oaxaca } \\
\text { Ayuntamiento }\end{array}$} & \multicolumn{1}{c}{$\begin{array}{c}\text { Mérida } \\
\text { Catedral }\end{array}$} \\
\hline 1870 & $\begin{array}{l}\text { Rogativa } \\
\text { propluvia } \\
\text { nivel IV } \\
(15-\text {-VI-1870). }\end{array}$ & & \\
1871 & $\begin{array}{l}\text { Rogativa } \\
\text { propluvia } \\
\text { nivel IV } \\
\text { (28-VIII-1871). }\end{array}$ & $\begin{array}{l}\text { Escasez de agua } \\
(6-\text {-III-1871). }\end{array}$ \\
1872 & & & $\begin{array}{l}\text { Rogativa } \\
\text { propluvia } \\
\text { nivel III } \\
\text { (20-VII-1872). }\end{array}$ \\
\hline
\end{tabular}


Tabla 28. Períodos 1875-1876 y 1882-1884

\begin{tabular}{lll} 
Año & Morelia & Catedral \\
\hline
\end{tabular}

1875 Rogativa pro pluvia nivel IV (22-VI-1875).

Rogativa pro pluvia nivel IV (18-VII-1875).

Rogativa pro pluvia nivel IV (16-VIII-1875).

1876 Rogativa pro pluvia nivel IV (10-VI-1876).

1882 Rogativa pro pluvia nivel IV (5-VIII-1882). Grave seca

1883

Grave seca

1884 Rogativa pro pluvia nivel IV (27-VI-1884).

Rogativa pro pluvia nivel IV (13-VII-1884). 



\section{Bibliografía}

Acuña, R., D. Stahle, M. Cleaveland y M. Therrell (2002), "Megadrought and Megadeath in 16th Century Mexico", Emerging Infectious Diseases vol. 8, núm. 4 [http:// wwwnc.cdc.gov/eid/content $/ 8 / 4 /$ contents.htm].

Aubry, A. (1982), "La Geografía de Chiapas", Boletín del Archivo Diocesano, vol. I, núm. 4, pp. 3-22, San Cristóbal de las Casas.

Aubry, A. (1989), "El Soconusco Colonial -cenizas de un tesoro-", Boletín del Archivo Diocesano, vol. III, núm. 6, pp. 3-49, San Cristóbal de las Casas.

Ayuntamiento Constitucional de Guadalajara-Instituto Jalisciense de Antropología e Historia-Instituto Nacional de Antropología e Historia (1970), Actas de Cabildo de la ciudad de Guadalajara- Dos tomos, ACG-IJAH-INAH, Guadalajara.

Barriendos, M. (1994), El clima histórico de Catalunya. Aproximación a sus características generales (ss. XV-XIX), tesis doctoral, Universitat de Barcelona, Barcelona.

Barriendos, M. (1997), "Climatic variations in the Iberian Peninsula during the late Maunder Minimum (AD 1675-1715): an analysis of data from rogation ceremonies", The Holocene, vol. 7, núm. 1, pp. 105-111.

Barriendos, M. (2005), "Climate and Culture in Spain -Religious Responses to Extreme Climatic Events in the hispanic Kingdoms (16 $6^{\text {th }}-19^{\text {th }}$ Centuries)", en Behringer, W., Lehmann, H. y C. Pfister (eds.), Cultural Consequences of the "Little Ice Age", Vandenhoeck \& Ruprecht, Götingen, pp. 379-414.

Camuffo, D. y S. Enzi (1992), "Reconstructing the climate of Northern Italy from archive sources", en Bradley, R. S. y P. D. Jones (eds.), Climate since 1500 A.D., Routledge, Londres, pp. 143-154.

Cortés, R. (2010), Inventario del Archivo Histórico de la diócesis de San Cristóbal de las Casas, Apoyo al Desarrollo de Archivos y Bibliotecas de México, México.

Cuevas, M. (1989), Sonora, textos de su historia, Instituto de Investigaciones José María Luis Mora, México.

Florescano, E. (1976), Origen y Desarrollo de los problemas agrarios de México, Editorial Era, México.

Florescano, E. (1995), Breve historia de la sequía en México, Universidad Veracruzana, Xalapa.

Garza, G. y M. Barriendos (1998), "El clima en la historia”, Ciencias, núm. 51, pp. 22-25. 
Garza, G. (2000), Evolución en el paisaje de la cuenca de México durante la dominación española, tesis doctoral, Universitat de Barcelona, Barcelona.

Garza, G. (2014), "Caracterización de la Pequeña Edad de Hielo en el México central a través de fuentes documentales”, Investigaciones Geográficas, núm. 85, pp. 82-94.

Hernández, M. E. y G. Garza (2010), "Rainfall variability in Mexico's Southern Highlands (instrumental and documentary phases, 17th to 21st centuries)", en Karlin, N. L. y A. V. Shelutko (eds.), Environmental quality in the large cities and industrial zones: problems and management. Ecology and hydrometeorology of big cities and industrial zones (Russia-Mexico), vol. I, Analysis of the environment, Russian State Hydrometeorology, University of St. Petersburg, pp. 94-113.

Instituto Nacional de Estadística, Geografía e Informática (2010), Censo de Población y Vivienda 2010, [www.INEGI.org.mx: 10 de octubre de 2015].

Iturribarria, J. (1982), Historia de Oaxaca, primer tomo, Gobierno de Oaxaca-H. Ayuntamiento de Oaxaca, México.

Jauregui, E. (1995), "Algunas alteraciones de largo período del clima de la Ciudad de México debidas a la urbanización. Revisión y perspectivas", Investigaciones Geográficas, núm. 31, pp. 39-49.

Lamb, H. (1995), Climate history and the modern world, Routledge, Londres.

Le Roy Ladurie, E. (1990), Historia del clima desde el año mil, Fondo de Cultura Económica, México.

López Cogolludo, D. (1867), Historia de Yucatán, Imprenta de Manuel Aldana Rivas, Mérida.

Martín Vide, J. y M. Barriendos (1995), "The use of rogation ceremony records in climate reconstruction: a case study from Catalonia (Spain)", Climatic Change, núm. 30, pp. 201-221.

Martín Vide, Javier (2009), "Conceptos previos y conceptos nuevos el estudio del cambio climático reciente", Investigaciones Geográficas, núm 49, pp. 51-63.

Mazín, O. (1996), El Cabildo Catedral de Valladolid de Michoacán, El Colegio de Michoacán, Zamora.

Menéndez, C. (1937), Noventa años de Historia de Yucatán (1821-1910), Compañía Tipográfica, Mérida.

Murillo, J. (1990), Historia de Guaymas, Gobierno del estado de Sonora-Instituto Sonorense de Cultura, Hermosillo.

Rabatel, A., V. Jomelli, P. Naveau, B. Francou y D. Grancher (2005), "Dating of Little Ice Age glacier fluctuations in the tropical Andes: Charquini glaciers, Bolivia, $16^{\circ}$ '", Comptes Rendus Geoscience, núm. 337, pp. 1311-1322.

Ramírez, J. F. (1851), Noticias Históricas y Estadísticas de Durango (1849-1850), Imprenta de Ignacio Cumplido, México. 
Sanz-Donaire, J. J. (2000), "New definitions of climate and climatic change", Bulletin of the Egyptian Geographical Society, núm. 73, pp. 127-144.

Servicio Meteorológico Nacional-Red Sinóptica de Superficie, Observatorio Meteorológico de Morelia. Información recabada y proporcionada por la doctora María Engracia Hernández Cerda.

Sociedad Sonorense de Historia-VIII Simposio de Historia Regional (1996), Sonora 400 años de ganadería, Sociedad Sonorense de Historia, Hermosillo.

Stahle, D. W., J. Villanueva Diaz, D. J. Burnette, J. C. Paredes, R. R. Heim, Jr., F. K. Fye, R. Acuna Soto, M. D. Therrell, M. K. Cleaveland y D. K. Stahle (2011), "Major Mesoamerican droughts of the past millennium", Geophysical Research Letters 38(5), DOI: 10.1029/2010GL046472.

Thompson, L. G., E. Mosley-Thompson, W. Dansgaard y P. M. Grootes (1986), "The Little Ice Age as recorded in the startigraphy of the Tropical Quelccaya Ice Cap", Science, vol. 234, no. 4774, pp. 361-364.

Thordarson, T. y S. Self (1993), "The Laki (Skaftár Fires) and Grímsvötn eruptions in 1783-1785, Bulletin of Volcanology, vol. 55, núm. 4, pp. 233-263.

Tortolero, A. (1996), "Historia Agraria y medio ambiente en México», Noticiario de Historia Agraria 11, pp. 151-178.

Villanueva-Díaz, J., L. Vázquez-Selem, A. Gómez-Guerrero, J. Cerano-Paredes, N. A. Aguirre-González y O. Franco-Ramos (2016), "Potencial dendrocronológico de Juniperus monticola Martínez en el Monte Tláloc”, Revista Fitotecnia Mexicana, vol. 39, núm. 2, pp. 175-185. 
Variabilidad climática en México a través de fuentes documentales (siglos XVI al XIX), editado por el Instituto de Geografía, se terminó de imprimir el 30 de noviembre de 2017, en los talleres de Impretei S.A. de C.V., Almería, núm. 17, Postal, Benito Juárez, 03410, México, Cd. Mx.

El tiraje consta de 200 ejemplares impresos en digital sobre papel cultural de 90 gramos para interiores y couché de 250 gramos para los forros. Para la formación de galeras se usó la fuente tipográfica Adobe Garamond Pro, en 9.5/10, 10/12, 11/13 y 15/17 puntos. Edición realizada a cargo de la Sección Editorial del Instituto de Geografía de la Universidad Nacional Autónoma de México. Revisión y corrección de estilo: Raúl Marcó del Pont Lalli. Diseño, formación de galeras y cuidado de la impresión: Laura Diana López Ascencio. Imagen de portada: Procesión Santo Cristo, Exconvento Singuilucan, Hidalgo. Anónimo. Fotografía/cortesía: Rafael Doniz. 
Variabilidad climática en México a través de fuentes documentales (siglos XVI al XIX)

Gustavo G. Garza Merodio

El conocimiento de la variabilidad climática en México está por escribirse, no solo en lo que respecta a los tiempos geológicos sino a los históricos. A la fecha, la única fuente precisa de la que disponemos para la reconstrucción paleoclimática son los registros obtenidos por medio de instrumentos meteorológicos, pero en Iberoamérica su resolución temporal difícilmente llega a 140 años, y en Europa occidental y Norteamérica no va más allá de mediados del siglo XVIII. El resto de esta empresa se lleva a cabo echando mano, por un lado, de aproximaciones de origen físico-biológico (dendroclimatología, análisis de sedimentos lacustres y marinos, así como el estudio de corales, cascos de hielo y glaciares) y, por otro, de datos antrópicos, provenientes de fuentes documentales. En el caso de México, la existencia de este último tipo de recursos para el estudio del clima, particularmente en el centro y sur del país, subsana la ausencia de otras aproximaciones fidedignas a lo largo de los últimos quinientos años.

El trabajo de Gustavo Garza, fundamentado en el impresionante cúmulo de información que le brinda el cuidadoso estudio de los registros de rogativa, principalmente de las ciudades de México, Puebla y Morelia, así como su comparación con los de Guadalajara, Oaxaca, Durango, Hermosillo, Mérida y San Cristóbal de las Casas, nos demuestra que la Pequeña Edad de Hielo, un periodo climático singular, dista de ser un enfriamiento global generalizado, como se ha sostenido. La información procedente de dichos registros denota los extremos que caracterizaron a esta anomalía climática, que coincidieron con una fase húmeda a lo largo de los siglos XVI y XVII y una seca a lo largo del siglo XVIII y primera mitad del XIX; argumentación surgida de pruebas glaciológicas en los Andes centrales.

Variabilidad climática en México a través de fuentes documentales (siglos XVI al XIX) es un aporte fundamental al conocimiento histórico de dichos eventos meteorológicos extremos durante un periodo extenso de nuestra historia, que Gustavo Garza reconstruye gracias a un trabajo erudito y cuidadoso de archivos que han arrojado una sorprendente riqueza sobre un tema central de nuestra agenda global.

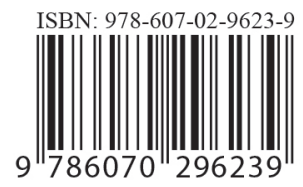

